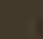




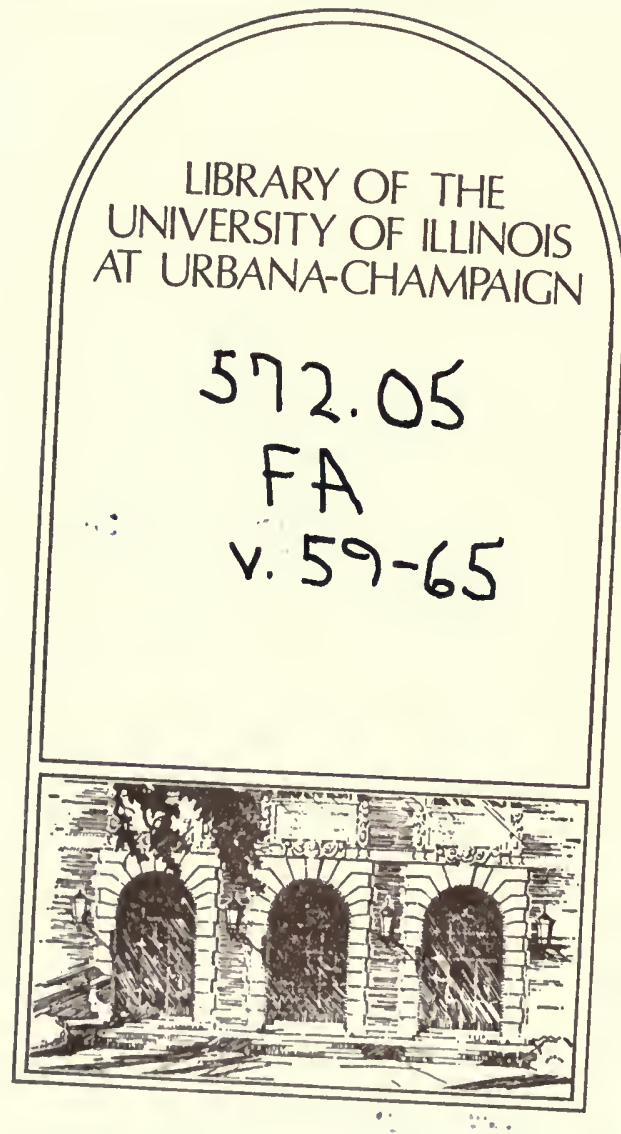




\section{CENTRAL CIRCULATION BOOKSTACKS}

The person charging this material is responsible for its renewal or its return to the library from which it was borrowed on or before the Latest Date stamped below. The Minimum Fee for each Lost Book is $\$ 50.00$.

Theft, mutilation, and undorlining of books are reasons for disciplinary action and may result in dismissal from the University.

TO RENEW CALL TELEPHONE CENTER, 333-8400

UNIVERSITY OF ILLINOIS IIBRARY AT URBANA-CHAMPAIGN

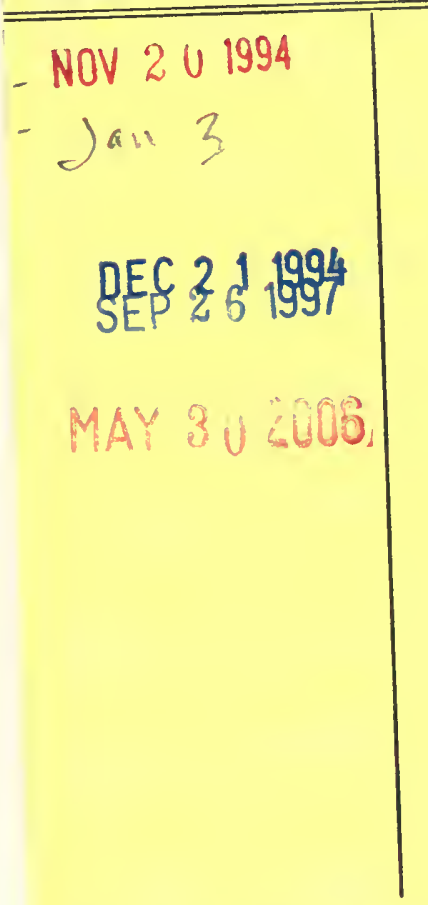

When renewing by phone, write new due date below previous due date. 



72.05

4

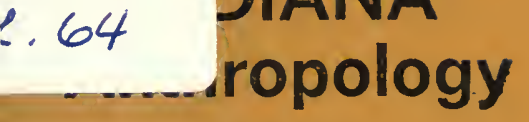

Published by Field Museum of Natural History

VOLUME 64

V. S. KHROMCHENKO'S COASTAL EXPLORATIONS

IN SOUTHWESTERN ALASKA, 1822

EDITED WITH AN INTRODUCTION BY

JAMES W. VANSTONE

Translated BY

DAVID H. KRAUS

NOVEMBER 23, 1973 





\title{
FIELDIANA: ANTHROPOLOGY
}

\author{
$A$ Continuation of the
}

ANTHROPOLOGICAL SERIES

of

FIELD MUSEUM OF NATURAL HISTORY

VOLUME 64

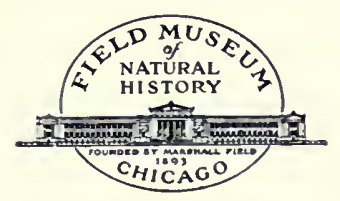

FIELD MUSEUM OF NATURAL HISTORY CHICAGO, U.S.A. 



\section{S. KHROMCHENKO'S COASTAL EXPLORATIONS}

IN SOUTHWESTERN ALASKA, 1822 



\section{FIELDIANA Anthropology}

Published by Field Museum of Natural History

VOLUME 64

V. S. KHROMCHENKO'S COASTAL EXPLORATIONS

IN SOUTHWESTERN ALASKA, 1822

EDITED WITH AN INTRODUCTION BY

JAMES W. VANSTONE

Curator, North American Archaeology and Ethnology

Chairman, Department of Anthropology

Field Museum of Natural History

Translated BY

DAVID H. KRAUS

Slavic and East European Division

The Library of Congress

NOVEMBER 23, 1973

PUBLICATION 1172 
Patricia M. Williams

Managing Editor, Scientific Publications

Library of Congress Catalog Card Number: 73-86815

US ISSN 0071-4739

PRINTED IN THE UNITED STATES OF AMERICA

BY FIELD MIUSEUM PRESS 


\section{CONTENTS}

PAGE

List of Illustrations . . . . . . . . . . . . . . . . . . . . v

Preface . . . . . . . . . . . . . . . . . . . . 1

Introduction . . . . . . . . . . . . . . . . . . . . . . . . 4

Notes for the Introduction . . . . . . . . . . . . . . . . 35

References for the Introduction . . . . . . . . . . . . . . . . . . . 37

Preface to the Translation . . . . . . . . . . . . . . . . 40

Excerpts from the Journal of V.S. Khromchenko on his Voyage of 1822 . . 42

Notes for the Translation . . . . . . . . . . . . . . . . . . . . . . 86

References for the Translation . . . . . . . . . . . . . . . . . . . . 94 



\section{LIST OF ILLUSTRATIONS}

Text Figures

PAGE

1. Map of the north Pacific Ocean . . . . . . . . . . . . . . . . 5

2. Map of southwestern Alaska . . . . . . . . . . . . . . . . . . . . . 9

3. Map of the Norton Sound and Seward Peninsula region . . . . . . . 17

4. Glazunov's map of southwestern Alaska . . . . . . . . . . . . . . 27

5. Map of Nunivak Island . . . . . . . . . . . . . . . . . . . . . 59 



\section{PREFACE}

Few areas of North America have received more literary attention from travellers and tourists than has Alaska. During the late nineteenth and early twentieth centuries, when a trip north was an exciting adventure, it seemed that virtually everyone making an excursion through the Inside Passage or heading toward the gold fields of the interior wrote a book about his experiences. In addition to sharing their experiences with armchair travellers, many of these authors also attempted to give historical perspective to their writings by including brief but invariably superficial accounts of Russian exploration in the North Pacific in the years preceding the purchase of Alaska by the United States in 1867. Most of these accounts are little more than rewritings of the data in $\mathrm{H}$. H. Bancroft's History of Alaska, published in 1886 as one part of the author's multi-volumed history of the American West. Bancroft's uneven work, the first attempt to describe Alaska's eventful past in detail, is still the most comprehensive history of what is now the forty-ninth state.

Although in recent years highly competent professional historians have centered their research on various aspects of the history of Alaskan exploration, relatively little attention has been focused on Russian contributions. There is still no thorough, well-documented history in English of Russia's penetration into the Pacific northwest. Belatedly, however, historians and social scientists realize the significance of this era in the expansion of the North American frontier. It is clear that although the scientific contributions of Russian explorers may have been less notable than those of their British and American counterparts, important and significant observations were made on the geography, native peoples, and resources of the country.

One of the factors inhibiting the study of Russian exploration has, of course, been the Russian language in which, until recently, few American northern specialists in any field have been competent. It is not, however, a matter of language alone. Information on many of the most important voyages and travels exists only in archival sources or in esoteric Russian publications of the late eighteenth and 
early nineteenth centuries which are available in only a handful of libraries in this country. Even the published accounts often exist only in brief and highly condensed form. Thus while it has been relatively easy to become informed concerning the broad outlines of Russian exploration, the details have frequently been very elusive indeed.

This study is concerned with Russia's penetration into southwestern Alaska, an area peripheral to the Aleutian Islands and panhandle archipelago where most of her exploration and economic exploitation took place. The explorations of Vasiliy Stepanovich Khromchenko, although not among the more spectacular in the history of northern voyages of discovery, were instrumental in opening this new area to the fur trade and they have never been the subject of detailed treatment in any language. The journals which he and his second-in-command, Adolph Karlovich Etolin, kept during their first voyage in 1821 have never been published and are known primarily through the writings of contemporary historians. Khromchenko's journal of 1822, which is the subject of this study, was published only as excerpts in consecutive issues of the Russian periodical, Severnyy Arkhiv.

The explorations of Khromchenko and Etolin in 1821 are described in the introduction as is the related voyage of Mikhail Nikolaevich Vasilev and Gleb Semenovich Shishmarev which took place at approximately the same time. Detailed consideration is given to the activities of Vasilev and Shishmarev because they covered some of the same areas explored by Khromchenko and Etolin, and their journals were never published. The accomplishments of all four explorers deserve to be known to a wider audience.

My purpose in this study is not only to reproduce Khromchenko's 1822 journal in the only version that is available, but to place his achievements, and the related achievements of others, in the framework of the development of the fur trade and the expansion of Russian influence in Alaska. In this manner, I hope to call attention to important and generally neglected events in the history of Russian America.

Russian proper names and other words in the introduction and in Khromchenko's journal have been transliterated according to a modified form of the Library of Congress system. The reader should remember that all dates are according to the Georgian calendar which was 12 days behind the Julian calendar in the nineteenth century. 
For critical comments and helpful suggestions during the preparation of this study, I am grateful to Dorothy Jean Ray. Her thorough knowledge of historical developments in the Norton Sound region has helped me to avoid a number of embarrassing errors. I also wish to express my thanks to Dr. Michael Krauss of the University of Alaska who helped me to formulate my interpretive comments concerning the Eskimo vocabularies collected by Khromchenko.

The translation of Khromchenko's journal was undertaken with financial support from the James R. Getz Fund of Field Museum of Natural History. David H. Kraus of the Library of Congress, translator of the journal and some of the material used in the introduction, also performed many editorial services. His interest and enthusiasm are much appreciated. Dr. Henry N. Michael of Temple University helped to resolve certain problems of terminology which had puzzled both the translator and the editor. Valuable assistance in obtaining biographical information on Khromchenko and Etolin was provided by Dr. Erna V. Siebert of the Institute of Ethnography in Leningrad and Dr. Svetlana G. Fedorova of the same institution in Moscow.

Finally, a very special debt of gratitude is due my wife, Dr. Mary Helms VanStone, who read the manuscript critically and offered her support and encouragement at every stage of its preparation. 


\section{INTRODUCTION}

Before the end of the sixteenth century, Russian fur traders had crossed the Urals, gradually extended their operations eastward across northern Asia, and established themselves on the shores of the Bering Sea. After reaching salt water, it was only natural that these Cossack adventurers would extend their explorations along the coast. By the early eighteenth century, rumors began to circulate among these intrepid travellers and traders concerning a continent said to lie to the east.

In the course of time, these rumors reached St. Petersburg where Tsar Peter the Great was quick to realize their importance. He ordered the organization of an expedition which was directed to extend the explorations of the Cossack navigators and to provide proof of the separation of Asia and America. The command of this expedition was given to Vitus Bering, a Dane and fleet captain in the Russian navy. After crossing Siberia, Bering built two small vessels at Okhotsk and, in July of 1728, sailed northward along the coast of Siberia as far as East Cape. Having passed through the strait which today bears his name, Bering returned to Okhotsk without having sighted the American continent. He did, however, report the existence of St. Lawrence Island.

Although Bering believed that he had definitely established the separation of Asia and North America, his evidence was so meager that most geographers refused to accept it. In fact, it was not until the third voyage of Captain James Cook a half century later that convincing proof of separation was obtained.

The interest aroused by Bering's first voyage led to the organization of a second expedition which, because of its size and the difficulties of travel, was six years in crossing Siberia. Finally, in June of 1741, this expedition sailed from Kamchatka in two vessels commanded by Bering and Aleksey Chirikov. The ships soon separated and on July 18 Bering sighted the American coast in the vicinity of Mt. St. Elias; a few days later a landing was made on Kayak Island. Sailing southwest, the party sighted the Shumagin Islands 


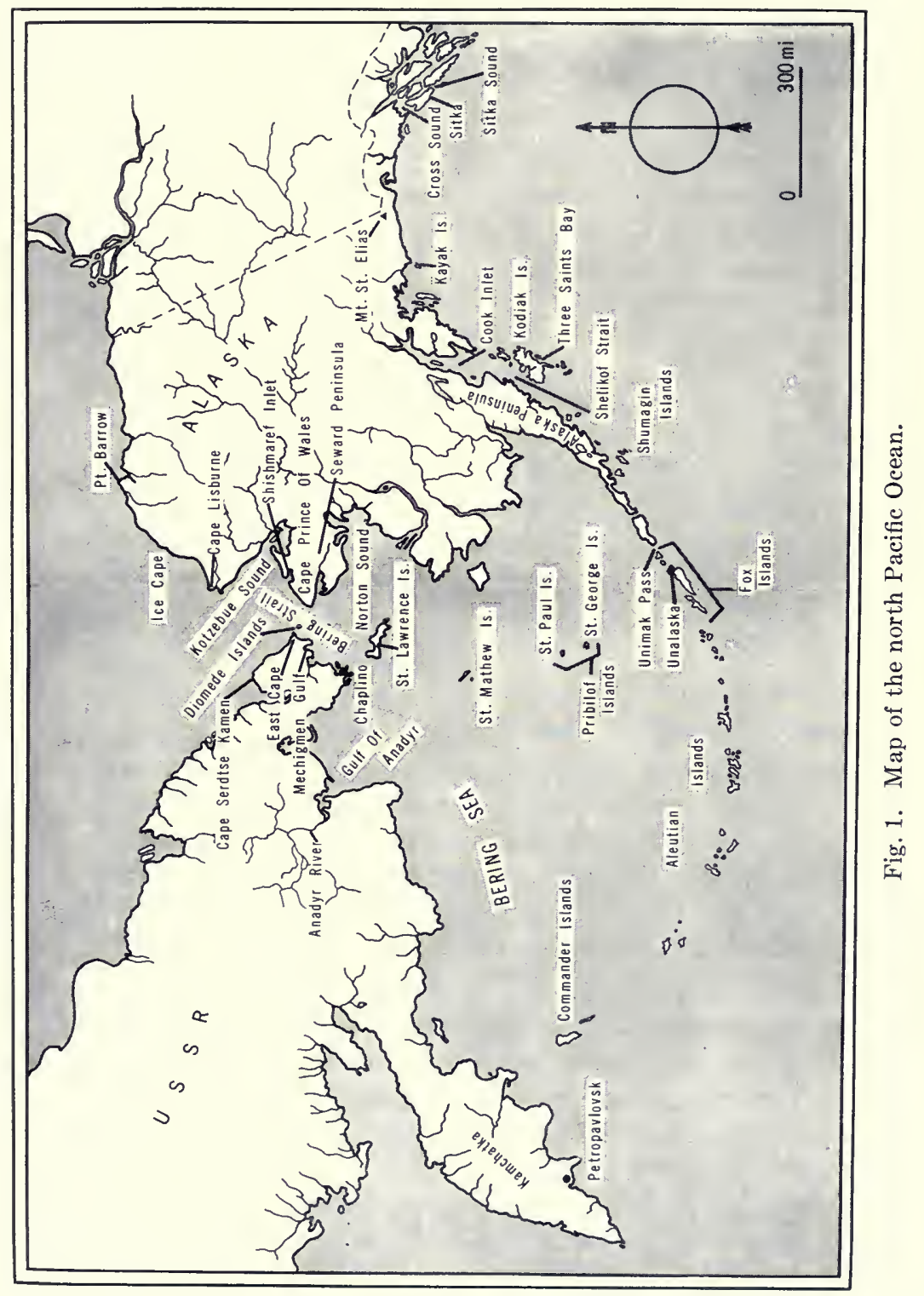


and continued westward along the Aleutian chain. Scurvy broke out and the ship was eventually wrecked on Bering Island in the Commander group off the coast of Kamchatka. Many died during the winter, including Bering. The next summer the survivors built a small vessel from the wreckage and returned to Kamchatka.

After becoming separated from Bering, Chirikov sailed eastward and on July 15 sighted the continent near Cross Sound. An attempt to land resulted in the loss of two boats and the death of nearly a third of his crew at the hands of the Tlingit Indians. Chirikov hastily returned to Kamchatka, sighting a few of the Aleutian Islands during his voyage. ${ }^{1}$

Following Bering's explorations and discoveries, Russian fur hunters began to exploit those areas of the north Pacific where fabulous riches in furs had been reported. These hardy Siberians reached the Commander Islands within two years after the return of Bering's party. Subsequently, in crude, ill-equipped, and poorly provisioned ships manned by crews who knew little of seamanship, these roving hunters and traders succeeded in pushing their way eastward along the Aleutian chain to the mainland of Alaska. ${ }^{2}$

Some of these fur hunters reached Kodiak Island as early as 1762 and by that time it was already apparent that foxes, sea otters, and other furbearers were becoming scarce in the Aleutians. Because the hunting and trading voyages were growing less profitable, it was necessary to look for new areas to exploit toward the northeast. Up to this time, fur gathering had been in the hands of individual entrepreneurs or a few small companies. However, in 1781, a wellorganized company of eastern Siberian merchants was formed to exploit the American fur trade. The leader of this new organization was Grigoriy Ivanovich Shelikov, an Irkutsk merchant who, in 1783, supervised the establishment of a small colony at Three Saints Bay near the southwestern end of Kodiak Island. From there the Shelikov Company extended its trapping and trading operations to the neighboring islands and mainland.

In 1792 Aleksandr Andreevich Baranov was appointed chief director of the company's American interests, a post which he held for 25 years. Virtually alone he developed the company to the point where it was able to overcome its rivals for control of the fur trade and become established, under the name of the Russian-American Company, as a state monopoly by imperial decree in $1799 .^{3}$ 
By the time Baranov was relieved of his duties in 1818, Russia's North American domain extended from the Aleutian Islands down the coast of southeastern Alaska to Sitka. He moved his headquarters from Kodiak Island to Sitka in 1800 and this small settlement became the capital of Russian Alaska. Although the Russians were familiar with the coastal areas in this picturesque region of numerous islands and deep bays, virtually nothing was known of coastal or interior regions to the north. Baranov was anxious to obtain more information concerning his extensive domain, but continual preoccupation with organizational problems, British and American competition, and difficulties with the Indians and Aleuts left little time for exploration. Nevertheless, early in the nineteenth century, as the number of fur-bearing animals continued to decline in the traditionally exploited areas, the Russian-American Company was forced to turn its attention to the vast area of southwestern Alaska north of the Alaska Peninsula. This was an unknown region in which it was hoped that new profits could be reaped through trade with the Eskimo inhabitants for beaver pelts. It was undoubtedly also true that in response to pressures exerted by other nations conducting explorations in northern waters, the Russians felt compelled to extend their influence into areas of the country with which they had not been traditionally associated.

In 1818, an expedition was dispatched to explore the region to the north of Bristol Bay. This party, under the direction of Petr Korsakovskiy, consisted of Fedor Kolmakov, Petr Gorokhov, Gavril Patyukov, Andrey Klimovskiy, and 20 Aleuts. The expedition was intended to open new areas to the fur trade, but also hoped to investigate rumors that white men, presumably descendants of earlier Russian explorers, were living on the "Kheuveren" River, believed to be located somewhere on Seward Peninsula. ${ }^{4}$

Korsakovskiy proceeded from Kodiak Island across Shelikof Strait and the Alaska Peninsula to Bristol Bay in the spring of 1818. From there Kolmakov led a detachment west to Cape Newenham by way of Kvichak and Nushagak bays, the lower reaches of the Togiak River, and Hagemeister Island. This trip required 41 days, the return journey to the Eskimo village of Ekuk at the mouth of the Nushagak River being made in mid-July. Kolmakov's party were almost certainly the first Russians to travel in this area.

Early in August, Korsakovskiy, leaving Kolmakov and a few others at the mouth of the Nushagak, led a detachment which ascended the Kvichak River to Iliamna Lake, Lake Clark, and the 
upper reaches of the Mulchatna River, a Nushagak tributary. On Iliamna Lake he met Eremy Rodionov, a local trader, who offered to lead a small group north to find the vaguely located "Kheuveren" River. The route followed by Rodionov and his party is uncertain, but they apparently reached the Kuskokwim River near the mouth of the Holitna and proceeded downstream to the vicinity of the present day village of Kalskag. By early September, the party had returned to the upper Mulchatna and from there Korsakovskiy and his men returned to Kodiak Island by way of Iliamna Lake and lower Cook Inlet.

Korsakovskiy's explorations of Iliamna Lake and Lake Clark were not the first European penetration of the interior west of Cook Inlet, Russian traders having operated in this area since the days when the Shelikov Company was competing with other trading companies for control of the fur trade in the Inlet. The Tanaina Indians, occupants of this region, were thoroughly familiar with Russian trade goods long before the arrival of the Korsakovskiy party.

In the summer of 1819, Korsakovskiy led another exploring party to Bristol Bay, this time by way of Iliamna Lake and the Kvichak River. From there the expedition proceeded to the mouth of the Togiak River and Hagemeister Island where the Russian-American Company cutter Constantine was waiting with supplies brought by sea from Kodiak. An exploration of the Kuskokwim River was planned and the supplies were for that purpose.

It was late in the summer when Korsakovskiy approached the Kuskokwim and, perhaps awed by the size of Kuskokwim Bay into which drains the second longest river in Alaska, he proceeded no further than Goodnews Bay. The Eskimos he met advised against an attempt to ascend the river, maintaining that many hardships would be encountered and that the Russians would have difficulty in obtaining food. So the expedition turned back, but not before learning from the Eskimos of the existence of a large island to the north and west between the mouths of the Kuskokwim and Yukon rivers. This was Nunivak Island and it figures prominently in the later explorations of Khromchenko. Korsakovskiy may even have heard of the mighty Yukon River, not to be seen by Russians until 1834 .

During Korsakovskiy's explorations in 1818, a detachment under Fedor Kolmakov had remained at the mouth of the Nushagak River while the rest of the expedition proceeded inland to Lake Clark and 


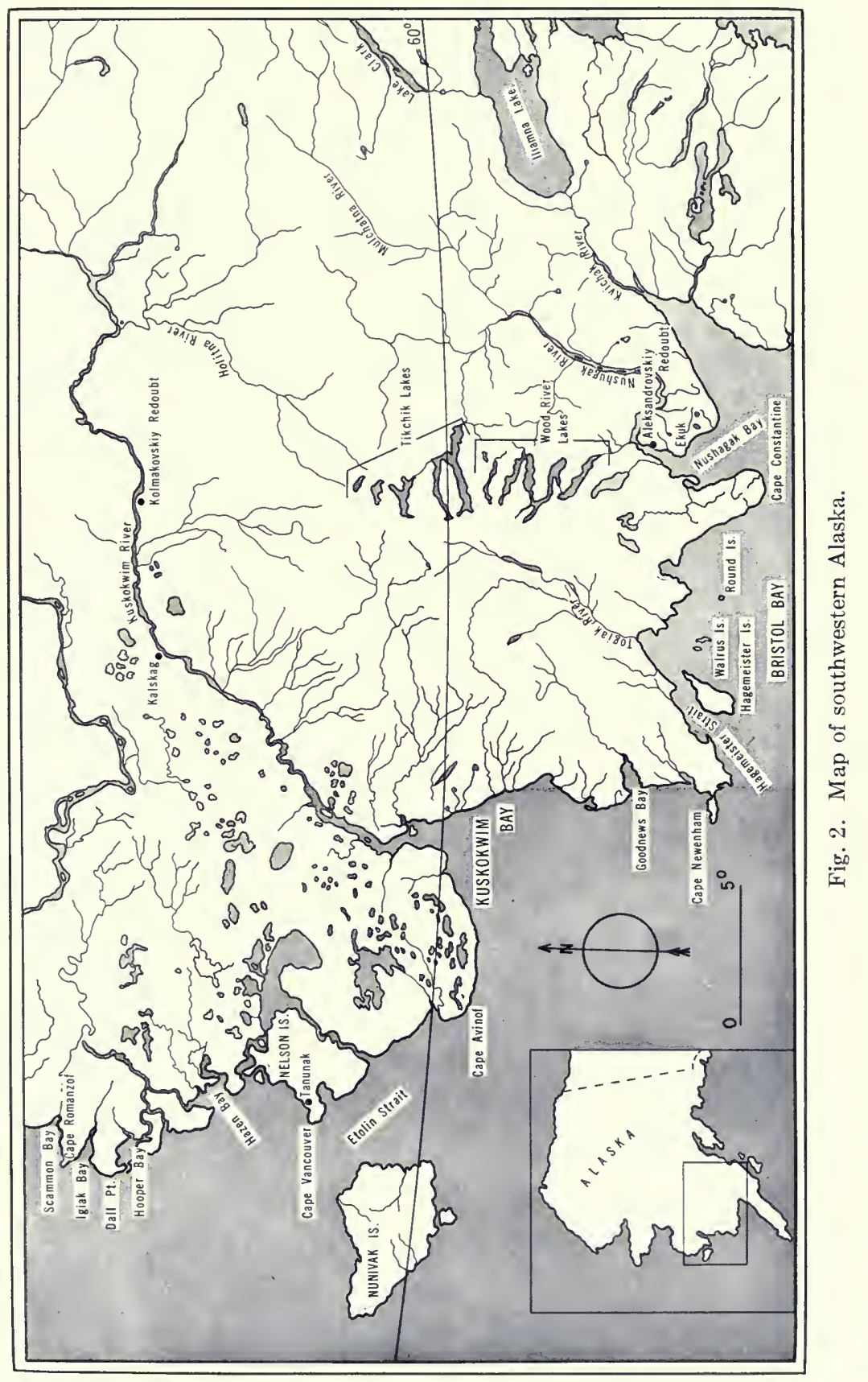


the Mulchatna. Kolmakov was to examine the area at the Nushagak's mouth as a possible location for a redoubt, and in the summer of 1819 a post was constructed. Chosen as the site for the first Russian-American Company establishment north of the Alaska Peninsula was a high bluff on the east bank of Nushagak Bay about 8 miles below the actual mouth of the river. The new redoubt was named Aleksandrovskiy, perhaps in honor of Tsar Aleksandr I, and Kolmakov, an energetic trader, rapidly established trade relations with the Aglegmiut Eskimos living in the vicinity of the post. Being frequently at war with their neighbors, the Kiatagmiut Eskimos of the Nushagak River, they were glad to place themselves under the protection of the Russians. Since the Aglegmiut were already somewhat familiar with Russian trade goods, it delighted them to be so close to an impressive new source of supply.

So ended the first Russian explorations in southwestern Alaska. As a result, the company learned something about the interior regions. Beaver were plentiful, the Eskimos friendly, and, most important of all, the region was apparently drained by a number of navigable rivers which would make penetration of the interior relatively easy. At the same time, residents of the interior had easy access to the coast. Aleksandrovskiy Redoubt seemed ideally situated to attract Eskimos with furs and to serve as a point of departure for explorations into the interior. This was indeed the case. Within ten years, such explorations were to take place virtually every summer, and within 25 years, all of southwestern Alaska would be opened to the fur trade.

The Russian-American Company was, of course, primarily interested in the fur trade and all its explorations were designed to find ways in which to increase that trade. But the company was also a state monopoly and could, at times, serve as an arm of Russian imperialism. Reacting to pressures from two other imperialist powers of the time, Great Britain and the United States, Russia felt insecure in its knowledge of and hold on the huge section of the North American continent which it claimed.

The Imperial Government watched with interest as the RussianAmerican Company expanded its activities into southwestern Alaska. A decision was made to sponsor some coastal explorations which would not only be of assistance to the company, but would, hopefully, rival those of Cook and Vancouver in their contributions to geographical knowledge. At the same time, the rest of the world 
would see that Russia was interested in and actively investigating all of Alaska, not just the Aleutian chain and the panhandle archipelago. Therefore, in 1819, by order of Tsar Aleksandr I, an expedition under the command of Captain-Lieutenant M. N. Vasilev was dispatched to describe and survey the northern coasts of Alaska and at the same time to look for the fabled Northwest Passage. The journals presumably kept by Vasilev and other members of the expedition were never published in full, although brief excerpts appeared in Russian and German periodicals. The contemporary historian, Vasiliy N. Berkh (1823a) also discussed Vasilev's explorations in the second volume of his history of northern discoveries.

On June 4, 1819, Captain Vasilev set sail from Kronstadt on the Gulf of Finland in two naval sloops, the Otkrytie (Discovery) and the Blagonamerennyy (Good Intent). The leader of the expedition was aboard the former while the latter was under the command of Captain-Lieutenant G. S. Shishmarev. Vasilev sailed directly to Kamchatka while Shishmarev went to Unalaska in the hopes of being able to procure an interpreter who would be useful when the expedition met northern coastal Eskimos. From there he sailed to St. Lawrence Island and then to Kotzebue Sound where Vasilev joined him on July 16, 1820.

Both vessels departed from Kotzebue Sound two days later and sailed northward along the Alaskan coast with the intention of surveying it in detail. Fog and ice hampered their surveys, however, and the two vessels were able to proceed only as far as $71^{\circ} 06^{\prime}$ north latitude, 35 miles north of Icy Cape. This was a very respectable achievement nonetheless, as it represents approximately the same latitude reached by Captain Cook in 1778 and was the most northern penetration of Alaskan coastal water's by the Russians up to that time. Vasilev gives no indication that he had any direct contact with the Eskimo inhabitants of these northern regions. The ships do not seem to have landed at any point between Kotzebue Sound and their farthest north and, because of fog and bad weather, may have been out of sight of land at least part of the time.

Proceeding south from the vicinity of Icy Cape, the two ships followed the coast to Cape Prince of Wales and then crossed the Bering Strait to East Cape and the Gulf of Anadyr on the Siberian coast. From there the expedition sailed toward St. Lawrence Island where Vasilev left Captain Shishmarev to make surveys while he headed for Unalaska by way of the Pribilof Islands. 
Like Captain Cook before them, the Russian navigators encountered difficulties with the moving pack ice as they attempted to survey close to shore along the arctic coast. Vasilev realized that the type of vessel needed for such surveys was a small boat of light sail that could hold close to the coast and take advantage of the open water between the shore and the pack ice. In fact, it was in just such a vessel that members of William Beechey's expedition reached Point Barrow, the first Europeans to do so, in 1826 (Beechey, 1831, chs. XI-XII). Since the Russian expedition carried with it the components for making a small boat, Vasilev decided to sail from Unalaska to Sitka where it could conveniently be assembled. Having left a member of his crew to carry out this task, he sailed from Sitka on October 25 to spend the winter in southern latitudes.

Shishmarev and Vasilev spent the winter in northern California and in the Hawaiian Islands. By early June, 1821, however, both the Otkrytie and the Blagonamerennyy were at Unalaska ready for the second season of surveys. Vasilev had stopped at Sitka in midMay to secure supplies, obtain interpreters, and take on board the newly constructed small boat.

Leaving Vasilev and Shishmarev for the moment as they prepare for their second season along the Alaska coast, we must turn our attention once again to the activities of the Russian-American Company. By this time the general manager, Matvey Ivanovich Muravev, had examined the journals and reports of Korsakovskiy's expeditions. What he learned impressed him and he decided that the company should support further explorations in the same area. The brig Golovnin and the cutter Baranov were to be employed for this purpose with the former commanded by the leader of the expedition, V. S. Khromchenko, and the latter by A. K. Etolin. Khromchenko's explorations were conceived on a much smaller scale than those of Vasilev. Not only was the area to be covered much more limited, but the advancing of geographical knowledge was distinctly subordinate to the necessity of obtaining information about the Eskimo inhabitants that would be useful to the company in planning the expansion of the fur trade. It can be assumed also that few political implications were attached to this expedition since at least part of the area had already been explored by the Russians. However, since Korsakovskiy had not proceeded beyond Goodnews Bay, but had brought back interesting information concerning the country to the north, Muravev was anxious for Khromchenko and 
Etolin to extend the explorations of the earlier party, thereby laying the groundwork for future trade in the new areas.

Since V. S. Khromchenko is the major figure in the explorations that most concern us in this study, it is worthwhile taking a brief look at his professional career. Little is known concerning the navigator's early life, but his name suggests that he was of Ukrainian extraction. In 1806 he entered navigator's school and was promoted to navigator's assistant, a non-commissioned rank, on July 21, 1815. His first assignment was on the brig Rurik under the command of Lieutenant Otto von Kotzebue, an early Russian round-the-world voyager who made important discoveries in the Bering Sea region (Kotzebue, 1821). While a member of this expedition, on July 1, 1817, Khromchenko was promoted to navigator 14th class, and on the expedition's return to Kronstadt two years later, to warrant officer.

Like other naval officers of the time, Khromchenko saw an opportunity for more interesting duty and rapid promotion through service with the Russian-American Company, to which he transferred in 1820. This transfer enabled him to receive his first command and, in 1821 and 1822, in the brig Golownin, he carried out the explorations which are the subject of this study. Following these expeditions, Khromchenko commanded company ships until at least 1833, during which time he took part in two round-the-world voyages and was rewarded and promoted to captain-lieutenant for providing the Imperial Botanical Gardens with more than 1,000 rare plants from Brazil. Beginning in 1834, Khromchenko appear's to have returned to service with the Imperial Navy and was stationed in the Baltic Sea between 1835 and 1840. On January 13, 1843 he retired from the service with the rank of second captain and died in 1849.

A. K. Etolin, although subordinate to Khromchenko on the voyages in 1821 and 1822, ultimately played a much larger role in the history of Russian America than did his superior officer. Of Finnish nationality, he first came to Alaska as a volunteer seaman on the sloop Kamchatka which was on a round-the-world voyage under the command of one of the greatest Russian navigators, Vasiliy Mikhailovich Golovnin. At Sitka Etolin entered the service of the RussianAmerican Company. Between 1819 and 1824.he commanded company ships which, in addition to the explorations with Khromchenko, made voyages to California and the Hawaiian Islands. Additional commands followed, during which Etolin voyaged throughout the 
Pacific Ocean as far north as St. Lawrence Island and south to the port of Valparaiso, Chile. For a while, in 1828, he was based in a settlement of traders on an island in the Kuriles.

During his career, Etolin was out of the company's service at least twice, once in 1825 when he returned to Kronstadt, and again in 1837 when he was promoted to captain-lieutenant and lived in St. Petersburg. It was there that his fortunes began to rise. He had remained a naval officer and from 1841 to 1845, as a first captain, he served as general manager of the Russian-American Company, the third in a line of naval officers to hold the company's highest position in Alaska. In 1847 Etolin retired from the navy with the rank of rear-admiral. He died in 1876.

The company's first sea explorations in southwestern Alaska began on May 3, 1821 when Etolin sailed from Sitka. ${ }^{5}$ He reached Hagemeister Island on the 30th and three days later dropped anchor at the mouth of the Nushagak River. After completing various assignments in that area, he put to sea on June 29 for Goodnews Bay where he met Khromchenko in the Golovnin, the latter having left Sitka on May 27. One of the assignments given to the expedition related to a rumor that Russians were living somewhere on Seward Peninsula. The Korsakovskiy expedition in 1818 was supposed to have investigated this rumor, as previously noted, but apparently they were not successful in obtaining the kind of information that satisfied the company. At the time there was considerable speculation about the identity of these Russians, if in fact they did exist. Some believed they would turn out to be descendants of survivors of the Deshnev expedition which may have passed through Bering Strait in 1648 and was, in the 1820's, little known (Berkh, 1823b). ${ }^{6}$ Khromchenko and Etolin hoped to meet the Eskimos who had described such people to Korsakovskiy, and after talking with some residents of the Goodnews Bay area for several hours, were convinced that the earlier explorer had misunderstood his informants.

Having obtained this information and completed their surveys in the Goodnews Bay vicinity, both vessels put to sea on July 12 but became separated the following day during a heavy fog. They did not meet again until the end of the expedition.

While Etolin was in Bristol Bay and Khromchenko was making his way toward Goodnews Bay, Vasilev and Shishmarev were at Unalaska in early June making plans for their second season of exploration in northern waters. Shishmarev was directed to carry out sur- 
veys along the northeast coast of Asia, while Vasilev, with the help of the newly-constructed ship's boat, described the Alaskan coast between Bristol Bay and Norton Sound. Vasilev also planned to proceed northward in the Otkrytie in a second attempt to find the Northwest Passage. On June 27 the Blagonamerennyy set its course for the shores of Asia, while Vasilev sailed to the Pribilofs and, having verified the geographic position of these islands, proceeded to Cape Newenham.

At Cape Newenham, Vasilev appointed a member of his crew, Lieutenant A.P. Avinov, commander of the ship's boat and instructed him to describe the Alaskan coast between capes Newenham and Darby and then rejoin the Otkrytie at Stuart Island on July 20. If his surveys had not been completed by this date, Avinov was to continue until August 15 at which time, if he did not meet his commander in Norton Sound, he was to winter either at Unalaska or in Petropavlovsk harbour on the coast of Kamchatka.

The ship's boat and the Otkrytie separated on July 6 and Vasilev headed for Cape Stephens. On the 11th he sighted an island which was not marked on his maps. On going ashore, probably at some point along the northwest coast, he learned that the island was called Nunivak and was not far from the Alaska mainland. The Eskimos he met indicated that they had not previously been in direct contact with Europeans. Vasilev, after naming the island Otkrytie, apparently made no attempt to survey it and departed the following day for Norton Sound. His failure to do any surveying is somewhat surprising since he must have realized the importance of his discovery. He may also have been aware that an island had been reported in this general area by the Korsakovskiy expedition in 1819. Vasilev's route from Nunivak to Norton Sound would presumably have taken him around the western tip of the island and provided the opportunity for surveying many miles of coastline. Perhaps he believed that Avinov in the ship's boat could be counted on to perform this work. In any event, Vasilev arrived at Cape Darby on the 19th and when the ship's boat failed to appear on the 20th, he sailed southward.

While Vasilev was sailing toward Norton Sound, Etolin in the Baranov was enroute to the mouth of the Kuskokwim River which he reached on July 17. There the party met a large number of Eskimos who claimed they had no previous contact with Europeans. It seems virtually certain, however, that these people had at least some previous knowledge concerning the Russians, if only because of the 
explorations of the Korsakovskiy party in the general area two years earlier.

Etolin spent about six days in Kuskokwim Bay making observations and describing the coastline. While gathering information from the local Eskimos, he learned of the existence of Nunivak Island which was previously unknown to him. Leaving Kuskokwim Bay on July 23, the Baranov sailed to the northwest and on the 28th, Etolin sighted what he presumed to be the island. He anchored off shore, apparently in the vicinity of Cape Mendenhall, and some Eskimos came on board. From them he learned that he was, indeed, off the coast of Nunivak. The following day the coast of the Alaska mainland was visible at a distance of 25 miles.

Etolin intended to sail through the strait which today bears his name, but was prevented from doing so by an unfavorable wind. $\mathrm{He}$ named the strait after Captain James Cook and then bore away to the northeast with the intention of circumnavigating the island. Again unfavorable winds intervened and he was prevented from accomplishing this goal. Nevertheless, he was successful in describing some of the island and in determining its extent from east to west. The Baranov then headed north to Norton Bay where Etolin hoped to meet Khromchenko in the Golovnin.

Khromchenko, meanwhile, after becoming separated from the Baranov on July 13, proceeded north and sighted the coast of Nunivak Island on July 16 and 17 . However, since the weather was foggy, he decided to postpone further explorations in that area and head straight for Norton Sound.

On the 22nd he entered Norton Bay and became the first European to visit Golovnin Bay. According to contemporary historian V. N. Berkh (1823a, p. 55), Khromchenko originally named it Muravev Bay after the general manager of the Russian-American Company. The latter persuaded him to change the name to Golovnin after the famous circumnavigator with whom the general manager had served on a round-the-world voyage. Khromchenko stayed in this newly discovered bay only briefly and then surveyed the coastline of Norton Sound to Cape Stephens after which he returned to Golovnin Bay on the 27th to secure water and firewood. During this second visit, the weather was much improved and he was able to survey a large part of the bay's shoreline including the mouth of the Fish River.

While riding at anchor in Golovnin Bay and during his extensive surveys of its coastline, Khromchenko had considerable contact 


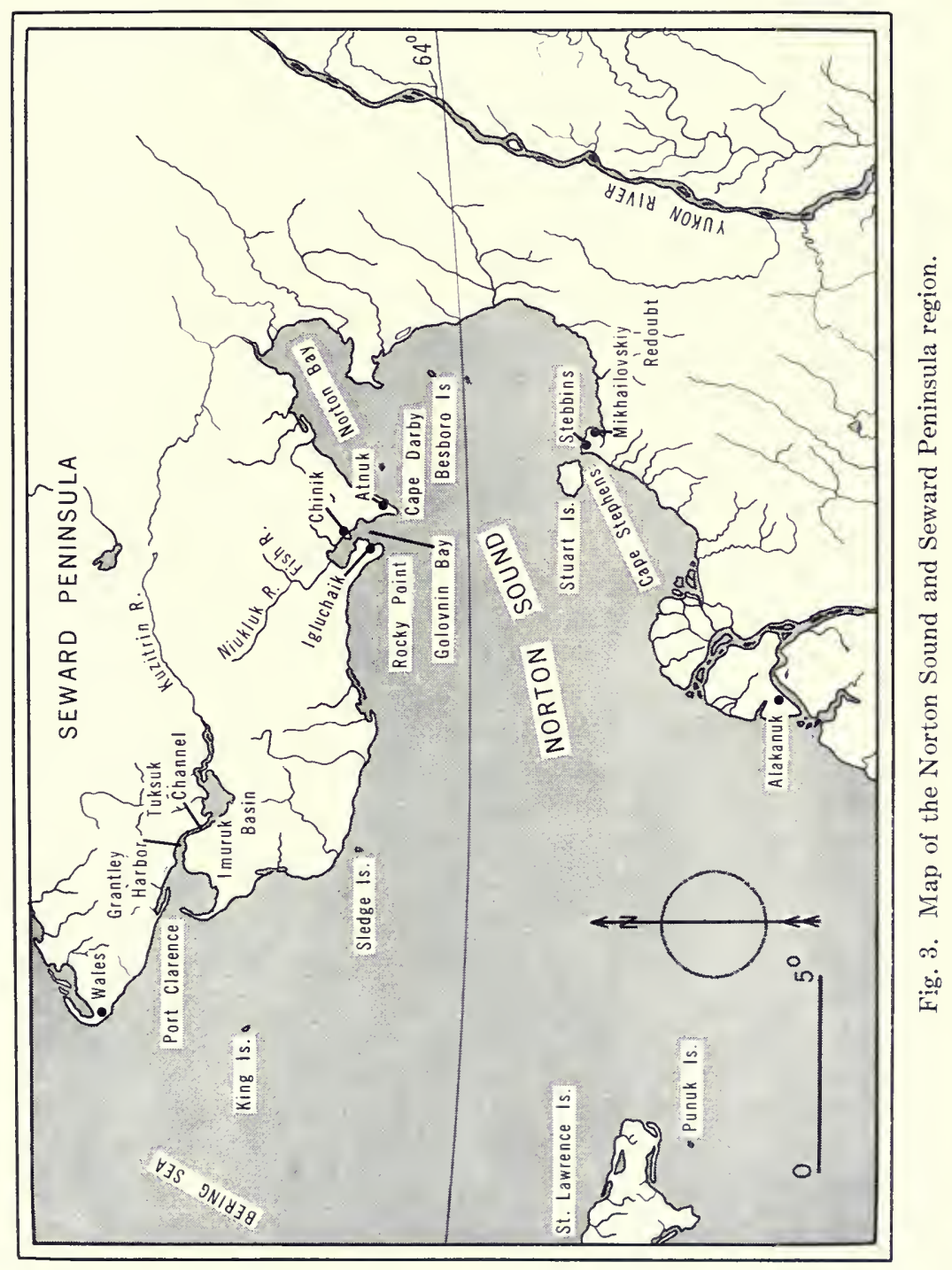


with the Eskimo population of the area. They provided him with information concerning the geography of the region, but he erroneously concluded that in some manner the bay connected with Shishmaref Inlet. The information he obtained increased his interest in the interior of Seward Peninsula and he was to pay particular attention to this area on his second voyage the following year.

Khromehenko left Norton Sound on August 10 and although Etolin in the Baranov arrived at Stuart Island on the 6th, the men he sent ashore to seek information concerning the whereabouts of the Golovnin could learn nothing. The Baranov then headed south, and on the 11th Etolin sighted an extensive headland. Believing himself to have been the first European to see this coast, he named it Cape Rumyantsev after Count Nikolay Petrovich Rumyantsev, a distinguished patron of Russian exploration. Rumyantsev had, from his personal resources, given financial support to Kotzebue's explorations aboard the Rurik in 1815-1819. The name of this cape appears on modern maps as Romanzof.

Unknown to him, Etolin was not the first European to visit this coast and describe the prominent cape. On July 4, 23 days before Etolin, Shishmarev in the sloop Blagonamerennyy had also sighted this headland. He had sailed from Unalaska on June 27 and hoped to explore further in this region but was prevented from doing so by the shallow water that is characteristic of much of the shoreline. He then proceeded to St. Lawrence Island, described its northern coast, and collected information on the Eskimo inhabitants. From there he sailed to the Gulf of Anadyr and, following his instructions from Vasilev, surveyed the coast and compiled ethnographic information on the Chukchis.

Shishmarev continued his surveys of the Asiatic coast until July 22 , but his work was hampered considerably by ice and bad weather. He then sailed north and reached $70^{\circ} 12^{\prime} \mathrm{N}$ latitude on August 1 when he sighted Cape Serdtse Kamen. A combination of ice, contrary winds, and bad weather caused him to abandon his northern explorations and to sail into Mechigmen Gulf for provisions. On August 15 Shishmarev headed once again for St. Lawrence Island. Here he surveyed the northern coast of the island before proceeding to St. Matthew Island and then Petropavlovsk which was reached on September 21.

Following his sighting of Cape Romanzof on August 1, Etolin in the Baranov continued southward, passed Cape Vancouver, and 
two hours later sighted the northern coast of Nunivak Island together with the strait which separates it from the mainland. $\mathrm{He}$ wished to stay close to the coast in order to conduct surveys, but heavy winds kept forcing him away from it. On the 12th he anchored off the western tip of the island and a shore party was able to obtain some information from the inhabitants.

Being unable to describe the whole of Nunivak Island, Etolin set sail for Unalaska and, plagued again by bad weather, was not able to enter the harbor until September 26. Two days later, after taking on wood and water, he departed for Sitka and reached that port on October 13, thus completing his part of the voyage.

We have already noted that Khromchenko left Norton Bay on August 10. He too sighted Cape Romanzof, but bad weather prevented him from making extensive surveys of the coast in this region. He then sailed for Nunivak Island, apparently with the intention of carrying out some of the surveys that he had not attempted earlier. Again the weather was bad, however, and Khromchenko may have wished that he had taken advantage of the earlier opportunity. No landing was made, but settlements were noted and people seen gathered in groups on the beach preparing to come out to meet the ship. But continuing contrary winds prevented them from doing so. The Golovnin then proceeded to St. George Island, arriving on the $17 \mathrm{th}$, and to Unalaska on the following day. $\mathrm{He}$ left Unalaska on the 24th and reached Sitka on September 7, approximately five weeks before Etolin.

We must now discuss the activities of Captain Vasilev in the Otkrytie as he worked his way into northern latitudes in hopes of locating the Northwest Passage. Having departed from Norton Bay on July 20, he proceeded north and approached Cape Lisburne on the 31st. Shortly thereafter, the ship encountered fog and ice which prevented a close approach to the shore. Progress northward was still possible, however, and on August 3, latitude $70^{\circ} 40^{\prime} \mathrm{N}$ was reached. The following day Vasilev sighted Icy Cape but extensive surveys were impossible because of the many ice floes which did some minor damage to the ship. Cape Lisburne was sighted on the 9th and on that day Vasilev abandoned his second attempt to conduct surveys in the Arctic Ocean and proceeded south, arriving at Cape Darby on the 13th. Like Captain Cook and others before and after him, the Russian navigator learned that progress northward in a large sailing vessel was virtually impossible much beyond latitude $70^{\circ}$. 
At Cape Darby Vasilev attempted unsuccessfully to learn the whereabouts of Lieutenant Avinov and the ship's boat. The Otkrytie then went on to Stuart Island where the inhabitants reported that they had never before seen Europeans although Etolin had visited the island earlier in the same month. It is interesting to note that while on the island, members of Vasilev's party learned of the existence of the Yukon River which was not seen by the Russians until Andrey Glazunov's explorations in 1833-34 (VanStone, 1959). Still lacking information concerning the whereabouts of Lieutenant Avinov, Vasilev sailed to Petropavlovsk, arriving on September 8 to find that the lieutenant had been there since August 19 .

Lieutenant Avinov had left Bristol Bay on July 6 and sailed in the direction of Cape Newenham. Heavy seas forced him into Hagemeister Strait on the 9th and during the next two days, he described the coast between Cape Newenham and Goodnews Bay. On July 13, the lieutenant left Goodnews Bay with the intention of continuing his surveys to the north. He kept encountering extensive tidal flats, however, and obviously possessed none of the skills necessary to navigate in such waters. The small ship's boat had a draft of 4 $\mathrm{ft}$. and the lieutenant frequently ran aground or was stranded at low tide. He also experienced difficulty in keeping the boat headed into the wind. In addition, the weather was continually stormy and the crew began to show signs of scurvy. So the plans for coastal explorations to the north, for which the ship's boat had been constructed and for which it was probably well-suited, were abandoned. Avinov decided to sail to Petropavlovsk where he arrived on August 19.7

Thus ended the voyage of Vasilev and Shishmarev, and the first attempt by the Russians to explore the northern coastal waters of their North American domain. Just 17 years later, in 1838, a party led by their countryman, Aleksandr Filippovich Kashevarov, traveling in Eskimo skin boats, reached a point 30 miles east of Point Barrow (Kashevarov, 1845). If Vasilev had managed to use his ship's boat rather than the Otkrytie in northern waters, this remarkable achievement might have been his. Be that as it may, in mid-October both the Otkrytie and the Blagonamerennyy set out on the return voyage and in nine months arrived safely at Kronstadt.

In evaluating the results achieved by these two expeditions, it is well to keep in mind that the explorations of Vasilev and Shishmarev were sponsored by the Imperial Navy, while those of Khromchenko and Etolin were the undertakings of a commercial enterprise, the Russian-American Company. Under these circumstances, it 
might be expected that more significant contributions to geographical knowledge would come from the former, while the work of the latter would be oriented toward establishing and improving the fur trade. It is doubtless true that the instructions given to Khromchenko and Etolin stressed the necessity of laying a foundation for successful trade relations. But it is also true that most of North America was explored by individuals or groups whose primary interests were economic. So it should come as no surprise to learn that this expedition also provided much useful geographical data on places until then practically unknown.

From the standpoint of geographical discovery, in fact, the explorations of Khromchenko and Etolin in 1821 stand out as a far more successful undertaking than the longer, more ambitious expedition sent out by the Imperial Navy. Although many factors were doubtless involved, it is tempting to attribute this fact primarily to superior and more imaginative seamanship on the part of the Russian-American Company employees.

Vasilev and Shishmarev must be credited with being only the second Russian expedition to seek the Northwest Passage in northern latitudes and to have reached further north in the Arctic Ocean than any Russian party up to that time; in fact $22^{\prime}$ further than Captain Cook. However, in spite of reaching the vicinity of latitude $71^{\circ} \mathrm{N}$ during the summers of 1821 and 1822, no surveys were attempted and virtually nothing was added to the information obtained by Cook more than 40 years earlier. Neither Vasilev nor Shishmarev had any contact with Eskimos north of Kotzebue Sound even though they were traveling along a heavily populated coast where Captain William Beechey visited several large villages just five years later. Certainly the achievements of the expedition in this area are very modest indeed when compared with that of Beechey or the journey of Kashevarov previously mentioned. It could be argued, perhaps, that Vasilev was considerably handicapped by his inability to use the ship's boat in northern waters. Certainly many of the problems with bad weather and moving ice which he encountered could have been avoided in a small vessel of shallow draft that could keep close to shore in these virtually tideless waters. But it must be remembered that Beechey, as well as many of the Franklin search vessels ${ }^{8}$ and the whaling vessels of later decades, were able to make detailed inshore surveys and frequent landings while operating from large boats. 
The failure of Lieutenant Avinov and the ship's boat to carry out any of the tasks assigned to him would seem to be a decisive factor in assessing the success or failure of Vasilev's expedition. Although it is to be regretted that the boat was never able to operate along the northern coast, it is equally unfortunate that Avinov made no attempt to carry out his assigned task of surveying the coast between capes Newenham and Darby.

And so, apart from Shishmarev's explorations along the Asiatic coast which do not concern us here, the only real achievements of the expedition were the placing of Nunivak Island and Cape Romanzof on maps for the first time, and the completion of surveys of St. Lawrence Island begun by Kotzebue in 1816. The discovery of Nunivak Island is clouded somewhat by a dispute between Vasilev and Etolin, both of whom claimed to be the first to have seen and described the island. Actually, as we have noted, the existence of the island was known to the Russians as it had been reported in the journals of Korsakovskiy's expeditions. But Vasilev did, in fact, sight the island 17 days before Etolin in July, 1821. However, the information which he provided concerning it was not only furnished after Khromchenko and Etolin had surveyed much of the shoreline, but was much less extensive and complete. Vasilev really did little more than sight the island, while Etolin carried out important and extensive surveys and had numerous contacts with the native inhabitants.

If the naval expedition of Vasilev and Shishmarev must be considered of relatively little importance in terms of geographical discovery and scientific achievement, that of Khromchenko and Etolin, with reference to the same criteria, can be considered a virtually complete success. Extensive surveys of the coast north of Cape Newenham were successfully carried out and much new information was obtained concerning the mouth of the Kuskokwim River. Although Etolin was unable to accomplish his goal of describing the entire coastline of Nunivak Island, the true position of the island was determined and a reasonable idea concerning its size and the nature of its coastal topography was obtained. Of equal importance was Etolin's success in surveying part of the strait separating Nunivak from the mainland. More complete surveys of the island and its vicinity were not carried out until United States Coast Guard vessels operated in the area at the turn of the century.

Khromchenko's surveys in Norton Bay were also of considerable significance and resulted in the placing of Golovnin Bay on maps for 
the first time. The navigator's contacts with Eskimos in this region were important not only from the standpoint of the fur trade, but because they provided sufficient information concerning the geography of interior Seward Peninsula to encourage Khromchenko to make further explorations in the Norton Bay area during his second expedition the following year.

Finally, it is worth noting that the expedition's contacts with Eskimos all along the coast provided a foundation for trade relations which later proved extremely profitable to the Russian-American Company. In fact, it is no exaggeration to state that the explorations of Korsakovskiy and the two voyages of Khromchenko and Etolin laid the groundwork for the opening up of all southwestern Alaska to the fur trade. They were followed between 1829 and 1832 by the interior explorations of Ivan Yakovlevich Vasilev ${ }^{9}$ and Fedor Kolmakov which brought the Eskimos of the Nushagak and Kuskokwim rivers within the sphere of influence of Aleksandrovskiy Redoubt. In the latter year Kolmakov established the redoubt on the middle Kuskokwim that was later to bear his name. In 1833 Mikhailovskiy Redoubt was constructed opposite Stuart Island and the way was open for Russian penetration of the Yukon. ${ }^{10}$ It is little wonder, therefore, that general manager Muravev was pleased with the results of Khromchenko's 1821 expedition and reported to the Board of Directors in St. Petersburg that the company had been repaid twofold for the expense of providing and maintaining the Golovnin and Baranov together with their crews.

The success of the 1821 expedition was such that the RussianAmerican Company determined to send out a second one the following year, also under the command of Khromchenko. It is extended excerpts from his journal of this second voyage, the only published first-hand account of either voyage, that are translated and edited in this volume. The main purpose of this second expedition, as outlined in orders from general manager Muravev, was, quite simply, to enlarge upon the explorations of the previous year. However, the general manager was particularly interested in obtaining descriptions of the Alaska coast from Cape Vancouver, the western tip of Nelson Island named by Etolin the previous year, to Stuart Island. It was this stretch of coast that both Vasilev and Shishmarev and the first Khromchenko expedition had failed to define except for locating the highly visible landmark, Cape Romanzof. Further, the expedition was directed to survey the coast from Stuart Island to a point parallel with the Diomede Islands and farther if 
possible. Also, of course, it was to gain as much information as possible concerning the inhabitants of this region. It is clear that the company was anxious to establish its influence along as much of coastal Alaska as possible in order to secure footholds from which the fur trade could spread inland. The fact that the Imperial Navy's expedition under Vasilev and Shishmarev had failed to provide detailed information on this area may also have influenced Muravev's decision to include more northern regions in the area to be explored by Khromchenko and Etolin in the summer of 1822 .

Readers of the translation and editorial comments which follow will, hopefully, be in a position to make their own assessment of the accomplishments of this voyage. But perhaps some guidance can be offered by considering these accomplishments in the light of three major considerations: 1) the significance of the expedition from the standpoint of exploration; 2) the information provided concerning the fur trade and company operations; and 3) ethnographic information obtained by Khromchenko concerning the Eskimo inhabitants of the areas covered by the expedition.

In assessing the significance of the geographical information obtained by Khromchenko and Etolin in 1822, it must be admitted that real accomplishments were few when compared with the results of exploration the preceding year. This was, of course, to be expected since the second expedition was designed, at least as far as southwestern Alaska was concerned, more to consolidate the discoveries of 1821 than to extend them into hitherto unvisited areas. Nevertheless, there were a number of significant geographical discoveries in 1822. The expedition was successful in determining beyond any possible doubt that there were no islands in the Pribilof group other than those already known. Also, additional information concerning the Walrus Islands was obtained and detailed surveys were conducted in the vicinity of Cape Mendenhall on Nunivak Island, along the island's east shore and in Etolin Strait. Other positive contributions include information obtained by Khromchenko from Eskimos living around the shores of Golovnin Bay concerning the drainage system of the southwestern region of Seward Peninsula. It would be almost the end of the nineteenth century before more detailed information concerning the geography of this area became known. Khromchenko also learned something of the coast of Seward Peninsula north of Golovnin Bay from Tungan, a well-traveled Eskimo who had journeyed to St. Lawrence Island and the coast of Siberia. 
One of the main purposes of the expedition, however, was to survey the Alaskan coast between Cape Vancouver and Stuart Island and to learn something of the inhabitants of this vast area. In this undertaking they were almost totally unsuccessful. Because of bad weather and shallow water, it was impossible to make careful surveys of the many bays and indentations which characterize the Bering Sea coast in the vicinity of the Yukon Delta. Similarly, surveys in the vicinity of Stuart Island were also hampered by bad weather and contrary winds. No landing was made between Nunivak Island and Stuart Island. As a result, no information was obtained concerning the people who inhabit the Yukon Delta, the most heavily populated Eskimo area in all Alaska. Thus Khromchenko failed to carry out a vital part of his orders. He failed in 1822 just as completely as Lieutenant Avinov of the Vasilev-Shishmarev expedition had failed the previous year.

It is probable that this failure to investigate the Yukon Delta and contact its inhabitants had some adverse effects on the fur trade after the establishment of Mikhailovskiy Redoubt in 1833, although the people of this region doubtless knew of the existence of the Russians and perhaps had obtained some trade goods indirectly as a result of Kolmakov's trading efforts in Bristol Bay. More important from the standpoint of geographical discovery and information, the expedition's failure to make landings and accurate surveys of the coastline in the Yukon Delta area probably postponed the discovery of the Yukon by Europeans until Andrey Glazunov reached this great river by an overland route from Mikhailovskiy in 1834 .

It is significant that European discovery of the Yukon came about as a result of interior explorations rather than an inland penetration from the coast. This fact emphasizes the barren, inhospitable nature of the coast in this area with the complex Yukon mouth and the bewildering number of sloughs that appear to lead nowhere. Perhaps Khromchenko cannot be blamed for his failure to penetrate this flat wasteland where significant tidal variations and mud flats add to the dangers created by many shoals and shallow water. And yet the expedition would appear to have possessed the means to make such surveys had Khromchenko been willing to take the time to do so. Etolin was on board the Golovnin for the specific purpose of directing the activities of the small, skin-covered Eskimo kayaks which had been ordered by the Russian-American Company, along with sufficient oarsmen, for the greater convenience of making coastal surveys. As far as can be determined from the published journal ex- 
tracts, these boats were used only once for this purpose and that was when Etolin was sent from Stuart Island to survey the strait which separates it from the mainland. At other times, the boats appear to have been used only to go ashore to visit Eskimo villages, to hunt, or to obtain fresh water.

The maps made by Khromchenko and Etolin in 1821 and 1822 have never been published. However, some information concerning geographical knowledge of southwestern Alaska following their explorations can be obtained by examining a map published in 1841 in connection with the interior explorations of Andrey Glazunov and based on a slightly earlier version published in 1839 (see fig. 4). ${ }^{11}$ This map clearly shows how little was known of the coastline between Cape Newenham and Stuart Island. The greater geographical detail observable between the mouth of the Nushagak River and Kuskokwim Bay is, of course, due primarily to the explorations of Korsakovskiy and Khromchenko, and similar detail in the Norton Sound region is partly the result of the latter's surveys. But the coastline in the Yukon Delta region is vaguely indicated and only the accurate positioning of Nunivak Island and Cape Vancouver can be attributed to data provided by Khromchenko and Etolin. It should be remembered that the interior geographical details shown on this map are the result of later explorations by I. Ya. Vasilev, Kolmakov, and Glazunov.

The published portions of Khromchenko's journal of 1822 end with the Golovnin at Stuart Island, and it is impossible to determine from available sources whether the expedition actually reached the parallel of the Diomede Islands in accordance with the instructions from general manager Muravev. At the end of the final installment of the journal in Severnyy Arkhiv is the notation "to be continued." A similar notation occurs after other sections previously published. It is certain, however, that no further extracts appeared in the journal. In an article about Khromchenko's career published by the Soviet historian, A. K. Burykin (1957, pp. 77-80), the author assumes that the second expedition ended at Stuart Island. However, no additional evidence is offered in support of this supposition, and it is probable that Burykin simply accepts the final installment in Severnyy Arkhiv as dealing with the expedition's most northern activities. Khromchenko notes several times in his journal that he is anxious to get on with the explorations and he attempts to avoid delay whenever possible. Therefore, it is difficult to believe that he did not proceed northward beyond Stuart Island in accordance with 


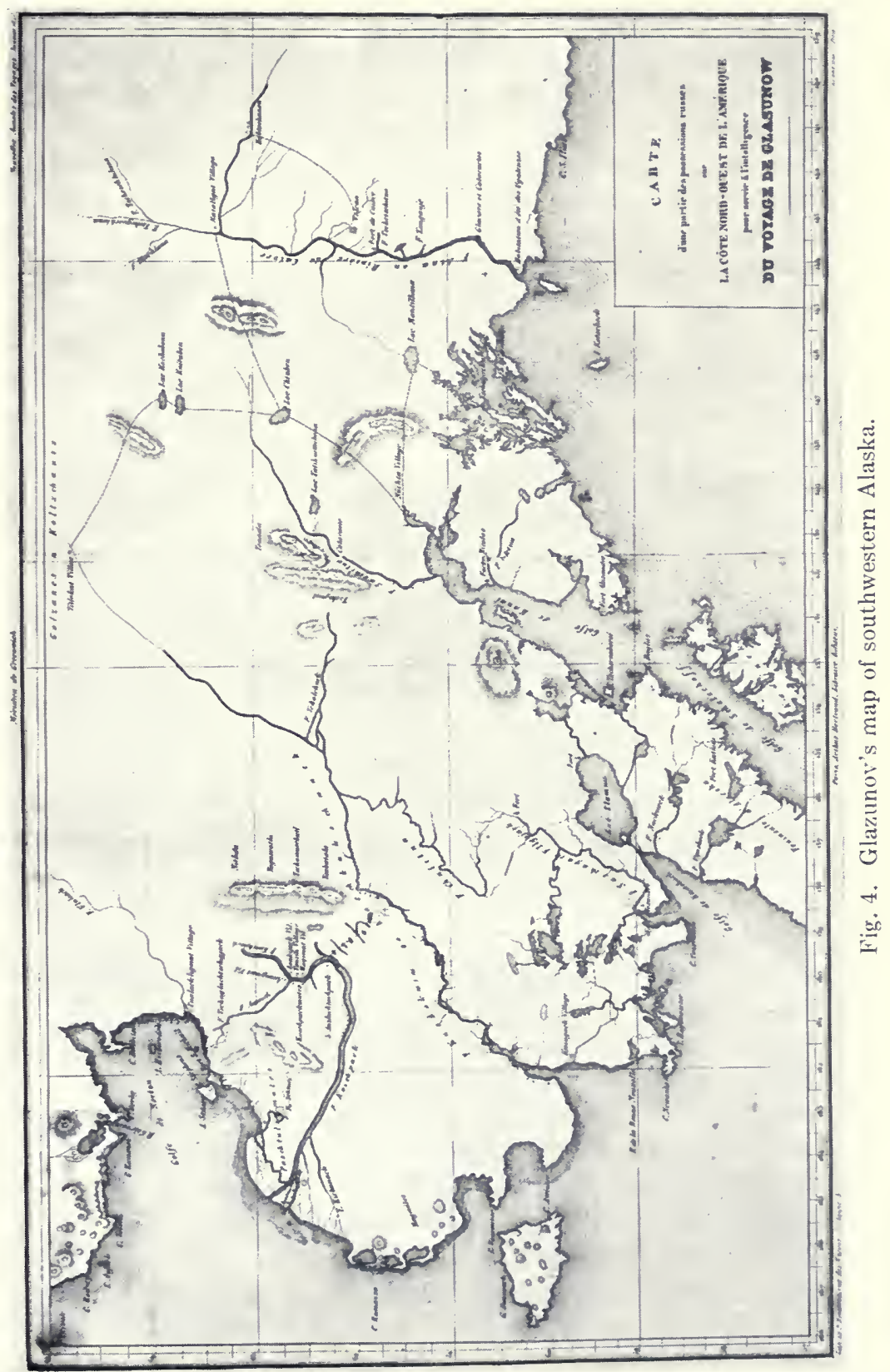


his instructions, particularly since the season was not advanced when he arrived in Norton Sound. It is unfortunate that the record of later stages of the voyage, if they actually occurred, have not been preserved.

Since opening new areas to the fur trade, rather than geographical discovery, was presumably of primary importance to Khromchenko, this may explain why he was unwilling, at times, to wait for better weather that might have allowed him to operate close to shore and make detailed coastal surveys. However, coastal surveys would also have enabled him to land at various locations and advance the fur trade through direct contacts with the Eskimos.

Be that as it may, Khromchenko did deal with matters concerning the fur trade almost as soon as he began his explorations in southwestern Alaska. Fedor Kolmakov, manager of Aleksandrovskiy Redoubt, was trading at the mouth of the Togiak River when the Golovnin arrived at Hagemeister Island on May 16. A small post had been established on the island the preceding year as an experiment and the company was giving some consideration to closing the establishment at the mouth of the Nushagak because of certain physical drawbacks, particularly the shallowness of the water and the treacherous shoals and tidal flats in front of the redoubt. There were rumors of large numbers of fur seals and sea otters in the vicinity of Hagemeister Island and it was also expected that a post at this location might be more convenient for the Eskimos living along the banks of the Kuskokwim River whom the company wished to draw into the fur trade as quickly as possible (VanStone, 1967, p. 7).

The Hagemeister experiment had proved to be less successful than anticipated and Khromchenko was directed by his superiors to assess the situation at the new post with a view to closing it and removing the residents to Aleksandrovskiy. This was done after consultations with Kolmakov. Certainly, there was never any doubt in Khromchenko's mind that the mouth of the Nushagak was the strategic location for a trading establishment. Hagemeister Island, on the other hand, was not particularly convenient for residents of the Kuskokwim River and had no other advantages with respect to the fur trade.

It is necessary to stress the importance of Khromchenko's evaluation of prospects for the fur trade in southwestern Alaska because there is every reason to believe that the company took them seriously and made important decisions on the basis of information obtained from the expedition. Khromchenko believed the Nushagak area to 
be heavily populated and he was right. At the time of his visit, there were approximately 500 people living in villages along the shores of Nushagak Bay and perhaps another 700 in settlements on the river, its major tributaries, and in the lakes area to the west. These numbers were decreased somewhat after a severe smallpox epidemic in 1837-1838, but the population again increased toward the middle of the century with an influx of people from areas to the north and south (VanStone, 1971, pp. 133-142).

Khromchenko's geographical knowledge of the upper Nushagak River region was, of necessity, based on rumors and guesses. Russian exploration of these areas was not to take place for another seven years. Nevertheless, he correctly surmised that the Nushagak would provide access to the interior and to the drainages of other important rivers flowing into the Bering Sea. The Eskimos reported abundant supplies of beaver throughout this area and Khromchenko noted that these people, increasingly acquainted with and dependent upon trade goods, were eager to barter fur.

The navigator's positive assessment of the future of the fur trade in southwestern Alaska helped resolve the company in its intention to retain the post at the mouth of the Nushagak. It must also have been instrumental in the decision to initiate the series of inland explorations by I. Ya. Vasilev, Fedor Kolmakov, and others which, within a period of less than 25 years, resulted in extensive explorations of the Nushagak, Kuskokwim, and Yukon drainages, and the establishment of Kolmakovskiy Redoubt on the Kuskokwim and Mikhailovskiy Redoubt northeast of the mouth of the Yukon. As on other occasions in the history of the fur trade in North America, it was possible to open a large area to trading activities in a relatively short time because the residents were already familiar with trade goods and ardently desired them. Some of these goods, particularly those in use among the more northern people contacted by the Golovnin had been obtained by way of Siberian trade routes through such middlemen as the inhabitants of Sledge Island off the coast of Seward Peninsula. Some items of European manufacture, however, could be traced either to the Vasilev-Shishmarev expedition of the preceding year or directly to Kolmakov's activities at the mouth of the Nushagak River, on Hagemeister Island, and at the mouth of the Togiak River.

At several places in his journal Khromchenko lists trade goods in the possession of and desired by Eskimos with whom he came in contact. The reader will note that each time the ship meets a group 
of Eskimos, these people come out in their skin boats, or members of the ship's company go ashore and active trading takes place. It was doubtless one of the duties of the expedition to engage in the fur trade whenever possible in order to obtain revenue for the company and help to offset the cost of outfitting the ship for the voyage. More important than this, however, may have been Khromchenko's desire to establish the Russians immediately in the role of providers of valuable items and indicate to the Eskimos the kinds of goods they were likely to receive in the future if they brought their furs to the Russian traders who were to follow. This was, of course, a longestablished procedure of North American explorations associated with the fur trade.

Although the Golovnin remained anchored off the village of Ekuk at the mouth of the Nushagak River for 12 days, it is not clear whether Khromchenko or Etolin actually visited the new trading post and settlement of Aleksandrovskiy Redoubt which was located about 5 miles above Ekuk. Unwilling to risk his ship in the treacherous tidal waters of Nushagak Bay, Khromchenko anchored off the Eskimo village and transported supplies and the personnel taken from Hagemeister Island to the post in a small boat. Later, Russian-American Company ships would frequently take on Eskimo guides at Ekuk before attempting the passage to the post (Van Stone, 1971, p. 88).

It is hardly possible that Khromchenko did not make at least one trip to the post with the boat and yet there is not a word about the settlement in his journal. Of course, Kolmakov was with him on the Golounin and, therefore, it would not have been necessary to go to the post to discuss company business with the manager. In any event, it is unfortunate that Khromchenko tells us nothing about Aleksandrovskiy as there is no published description of the redoubt until the early 1870 's, more than 50 years after its founding (Elliott, 1886, pp. 374-376). There is no plan or detailed description of the post in any of the known archival repositories and, as a result, virtually nothing is known concerning the appearance of Aleksandrovskiy during the Russian period. Khromchenko had an excellent opportunity to describe the small settlement in its earliest years and the various activities that went on there. That he failed to do so would seem to suggest that he was preoccupied with his orders from the company, the safety of his ship in unknown waters, and the necessity of heading north as soon as possible. 
Although the ethnographic data in Khromchenko's journal is neither extensive nor detailed, it is virtually the earliest information that exists concerning the Eskimo population of southwestern Alas$\mathrm{ka}$, and therefore important. Early in the journal there are brief descriptions of the clothing and boats of Eskimos from the Togiak River who had come to Hagemeister Island to trade with Kolmakov's small settlement. These Eskimos, like all others met by the expedition, desired tobacco and appeared to be dependent on it almost to the point of addiction. This trade item was known to Alaskan Eskimos before the Russians arrived in North America. There are indications that it was traded across Bering Strait from Russian posts on the Anadyr River as early as the middle of the eighteenth century and reached the people of southwestern Alaska through middlemen in the Seward Peninsula area (Zagoskin, 1967, pp. 100-103). When Captain Cook visited Norton Sound in 1778 he noted that the Eskimos there were familiar with tobacco, although it was not used by the inhabitants of Bristol Bay at that time (Cook and King, 1785, vol. 2 , pp. 436, 478). There is archaeological evidence for the use of tobacco in the Yukon Delta around 1800 and it must have reached Bristol Bay shortly thereafter, not long before the Russians brought it directly (Oswalt, 1952, p. 69). Kolmakov and other early nineteenth century traders thus found a ready market already existing for one of their most important trade items.

Khromchenko's journal provides useful information concerning population movements in the Nushagak River region. The earliest historic sources, of which Khromchenko is one, mention relations between the peoples of this area and those from other parts of southwestern Alaska, particularly the Kuskokwim River. It seems certain that the mixture of population in the Nushagak area began in the prehistoric period, but the newly established Aleksandrovskiy Redoubt served as an additional attraction for peoples from the north and south. Khromchenko was apparently the first to make a distinction between the coastal dwelling Aglegmiut and the Kiatagmiut who, at the time of contact, inhabited the banks of the Nushagak and Wood rivers and the area to the west possibly as far as and including the Wood River Lakes and Tikchik Lakes. The Kiatagmiut also occupied the upper Kvichak River and probably the lower end of Iliamna Lake. Members of Korsakovskiy's expeditions referred to the inhabitants of Nushagak Bay as the Glakmiut and these peoples have generally been equated with the Aglegmiut of Khromchenko (VanStone, 1967, ch. VII). 
There were already Kuskokwim Eskimos living in the vicinity of Aleksandrovskiy Redoubt at the time of Khromchenko's visit, and it seems likely that they frequented the area, at least seasonally, long before the coming of the Russians. Khromchenko mentions the Aglegmiut as having moved about a great deal and notes that they were apparently fairly recent immigrants to the Nushagak River region and on poor terms with the Kiatagmiut at the time the redoubt was established. The existence of the trading post, plus the active efforts of Kolmakov, was instrumental in stabilizing relations between the two groups. Khromchenko provides some basic ethnographic data on these coastal peoples as well as a vocabulary of 135 words.

Of even greater importance, perhaps, is the information Khromchenko's journal provides concerning the inhabitants of Nunivak Island. It is virtually certain that these people had not seen Europeans prior to the expedition's visits and his descriptions of them are the first in the published or unpublished literature. It is significant, however, that the islanders were familiar with European trade goods, had well-established trade contacts with coastal peoples at the mouth of the Kuskokwim River, and carried on a brisk trade with the crew of the Golovnin.

Khromchenko's failure to survey the coastline between Cape Vancouver and Stuart Island prevented him from meeting inhabitants of the tundra villages in the Yukon Delta region. Some of the coastal villages in this area, such as Hooper Bay, Scammon Bay, and Alakanuk, are large and of considerable antiquity. As previously suggested, the people living in these and other delta communities probably had no direct contact with Europeans until after Mikhailovskiy Redoubt was established in 1833 . It is somewhat paradoxical that although the Russians were successful in opening the interior of southwestern Alaska to the fur trade in a relatively short time, some of the coastal regions within their presumed sphere of influence remained virtually unknown and unvisited by outsiders until well into the American period. When Edward William Nelson, an American naturalist and collector of ethnographic materials for the Smithsonian Institution, visited Hooper Bay in December, 1878, he noted that the people appeared to have seen few if any white men in the past (Nelson, 1899, pp. 249-250). In fact, Nelson published the first detailed map of the coastal region between Hooper Bay and the Kuskokwim River and wrote the first description of the area from personal observation (1882). 
Compared to the interior, the delta area is rich neither in furs nor in mineral resources and, as Khromchenko quickly learned, the coastal waters are shallow and treacherous. This combination of inaccessibility with little in the way of attractive resources was sufficient to keep white trappers, traders, prospectors, and even missionaries out of the delta country until virtually the end of the nineteenth century. And yet in terms of subsistence resources, the area is a rich one where heavy and predictable annual runs of salmon enable people to live in larger settlements than anywhere else throughout the vast regions occupied by Eskimos.

When Khromchenko reached Stuart Island, he met large numbers of Eskimos from the nearby mainland, and members of the expedition visited a village near the present site of Stebbins. Here a limited amount of ethnographic information was obtained together with a vocabulary of 124 words. These are listed by Khromchenko with their counterparts obtained from the residents of Nunivak Island. The expedition also learned something about contacts between the people of Norton Sound and those of Sledge Island, who, as we have noted previously, acted as middlemen in the Siberian trade.

The expedition proceeded directly from Stuart Island to Cape Darby and Golovnin Bay, the scene of some of Khromchenko's most notable surveys in 1821 . There the party met a number of Eskimo acquaintances from the previous year along with a man who had traveled to St. Lawrence Island and the Siberian coast. Khromchenko obtained a vocabulary of 106 St. Lawrence Island words from this individual as well as some interesting information concerning movements of people in the Golovnin Bay-southern Seward Peninsula region. The published excerpts of the journal conclude with an account of a dance which the crew of the Golornin witnessed, and some brief comments concerning marriage practices and trade among the Eskimos of Golovnin Bay.

In making a general assessment of the information in published portions of Khromchenko's 1822 journal, it is necessary to remind ourselves once again that his explorations were not a voyage of discovery in the accepted sense, nor was he an ethnographer with intellectual interests in the culture of the people with whom he came in contact. As simply an advance agent for a fur trading company, his duties were to provide basic information that would assist his employers to make their plans for expanding the fur trade. There- 
fore, his geographical discoveries, while important, do not compare with those of some other navigators in northern waters. In fact, Khromchenko, although an experienced navigator, appears at time to have been quite hesitant and timid when compared to major figures like Cook, Vancouver, and Beechey. For obvious reasons, the Russian-American Company always pursued inland explorations with a good deal more vigor than those along the coasts.

The ethnographic information in Khromchenko's journal is admittedly sketchy. His interest in the Eskimos seldom went beyond recognition of the fact that they were customers for the company and the only persons who could provide furs for the trade. Since the people he met were already acquainted with European trade goods and anxious to take part in the fur trade, he may have believed it unnecessary to attempt to learn more about them and their way of life. But regardless of the sketchiness of his data, Khromchenko's comments on the Eskimos of southwestern Alaska are inevitably significant because they are the earliest that exist for this area. The same is true of the vocabularies. Because of their early date, they are extremely valuable for studies of Eskimo dialectology. Linguists can use these word lists as baselines against which to measure dialect changes that have taken place since 1822 .

Commercially and geographically, therefore, Khromchenko's voyage in 1822 represents a cautious probing by the Russian-American Company into an area outside the one in which they had traditionally operated. Nonetheless, the results of Khromchenko's explorations laid the groundwork for a profitable extension of the fur trade that served the company well during the last 40 years of its existence. General Manager Muravev may have foreseen this result of the expedition's achievements when, two years after its return, he requested the Admiralty Department to examine the journal of the brig Golovnin, together with two maps which accompanied it. The department noted the merit of Khromchenko's and Etolin's accomplishments and requested the naval chief of staff to reward and promote the two navigators (Burykin, 1957, p. 80). 


\section{NOTES}

1. For translations and interpretations of significant journals and logs of both Bering voyages, see Golder (1922). An excellent short summary of the explorations will be found in Tompkins (1945, chap. II).

2. Primary sources dealing with explorations immediately following those of Bering are translated and interpreted in Masterson and Brower (1948).

3. The standard history of the Russian-American Company is Tikhmenev (1861-1863).

4. In a previous publication (VanStone, 1967), I used Berkh (1823b) as a source for the explorations of Korsakovskiy. Recently, however, much more detailed and accurate information concerning these explorations, based on diaries in Soviet archives, has been published by Fedorova (1971, pp. 66-73) and this account is based on her work.

5. This account of the first Khromchenko-Etolin expedition is taken from Berkh (1823a, pp. 45-49).

6. For a concise description and evaluation of Deshnev's accomplishments, see Semyonov (1963, pp. 86-91).

7. For additional information concerning the explorations of Avinov, see Fedorova (1971, pp. 75-77).

8. Between 1848 and 1854 a number of English vessels explored the northwest coast of Alaska during the search for Franklin's third expedition.

9. Two naval officers named Ivan Vasilev served the RussianAmerican Company in the early nineteenth century. Ivan Filippovich Vasilev, a noted cartographer who arrived in Sitka in 1807, later commanded company ships and was drowned in an accident at Okhotsk, Siberia in 1812. Ivan Yakovlevich Vasilev entered the service of the Russian-American Company in 1821 and, in 18291830 , carried out extensive explorations in southwestern Alaska. In previous publications (VanStone, 1967, pp. 9-10; 1968, pp. 223-224; 
1970 , p. $13 ; 1971$, p. 21) I have confused the names of these two individuals. For a detailed discussion of the explorations of I. Ya. Vasilev, see Fedorova (1971, pp. 229-232).

10. For a detailed discussion of these explorations, see VanStone (1967, chap. I).

11. This map, reproduced in VanStone (1959), appeared originally in von Baer (1839, chap. 5), and was redrawn in Ternaux-Compans (1841). 


\section{REFERENCES}

BANCROFT, H. H.

1886. Alaska 1730-1885. San Francisco.

BeEChey, F. W.

1831. Narrative of a voyage to the Pacific and Beering's Strait, . . 2 vols. London.

BERKH, V. N. (compiler)

1823a. Kronologicheskaya Istoriya vesekh puteshestviy v Severnyya polyarnyya strany, Pt. II. St. Petersburg.

1823b. Puteshestvie uchenika morekhodstva Andreya Ustyugova, i sluzhiteley Rossiiskoy Amerikanskoy Kompanii Fedora Kolmakova i Petra Korsanovskago v 1819 godu. Severnyy Arkhiv, pt. 4.

BuRYKin, A. F.

1957. Chetyre plavaniya kapitana Khromchenko. Priroda, no. 3, pp. 77-80.

CoOK, J. and J. KING

1785. A voyage to the Pacific Ocean. Undertaken, by the command of His Majesty, for making discoveries in the northern hemisphere. 2nd ed., 3 vols. and atlas. London.

Elliott, H. W.

1886. Our arctic province. Alaska and the Seal Islands. Charles Scribner's Sons. New York.

Fedorova, S. G.

1971. Russkoe nacelenie Alyaski i Kalifornii, konets XVIII veka-1867 g. Moscow.

GOLDER, F. A.

1922. Bering's voyages. American Geographical Society, 2 vols. New York.

Kashevarov, A. P.

1845. Otryvki iz dnevnika korpusa flotskikh shturmanov poruchika A. F. Kashevarova, vedennogo im pri obozrenii polyarnogo berega Rossiyskoy Ameriki, po porucheniyu Rossiysko-Amerikanskoy kompanii v $1838 \mathrm{~g}$. SanktPeterburgskiya vedomosti, nos. 190, 192, 195.

Kotzebue, O. voN

1821. A voyage of discovery, into the South Sea and Beering's Straits, . . . 3 vols. London. 
Masterson, J. R. and H. Brower

1948. Bering's successors, 1745-1780. Univ. Wash. Press.

NELSON, E. W.

1882. A sledge journey in the delta of the Yukon, northern Alaska. Roy. Geograph. Soc. Proc., 4, no. 11, pp. 660-667, map facing p. 712.

1899. The Eskimo about Bering Strait. Eighteenth ann. rept., Bur. Amer.

Ethnol., pt. I. Washington.

OsWalt, W. H.

1952. The archaeology of Hooper Bay Village, Alaska. Anthropol. Papers Univ. Alaska, 1, no. 1, pp. 47-91.

SEMYONOV, Y.

1963. Siberia, its conquest and development. International Publishers' Representatives. Montreal.

Ternaux-Compans, $\mathrm{H}$.

1841. Extrait due Journal d'Andre Glasunow, contre-maître de la Marine Imperiale Russe, pendant son Voyage dans les Nordouest de l'Amerique. Nouvelles de Voyages et des Sciences Geographiques, 4ème serie, 10ème année (tome 89 de la collection), pp. 5-27.

Tikhmenev, P. A.

1861-63. Istoricheskoe obozrenie obrazovaniya Rossiysko-Amerikanskoy kompanii ...2 vols. St. Petersburg.

Tompkins, S. R.

1945. Alaska, promyshlennik and sourdough. Univ. Oklahoma Press.

VANSTONE, J. W.

1959. Russian exploration in interior Alaska. An extract from the journal of Andrei Glazunov. Pacific Northwest Quart., 50, no. 2, pp. 37-47.

1967. Eskimos of the Nushagak River: An ethnographic history. Univ. Wash. Press.

1968. Tikchik village: A nineteenth century riverine community in southwestern Alaska. Fieldiana: Anthropol., 46, no. 3.

1970. Akulivikchuk: A nineteenth century Eskimo village on the Nushagak River, Alaska. Fieldiana: Anthropol., 60.

1971. Historic settlement patterns in the Nushagak River region, Alaska. Fieldiana: Anthropol., 61.

VON BAER, K. E.

1839. Statistische und ethnographische Nachrichten uber die Russischen Besitzungen an der Nordwestkuste von Amerika: Gesammelt von dem ehemaligen Oberverwalter dieser Besitzungen, Contre-Admiral v. Wrangell. St. Petersburg. 
Zagoskin, L. A.

1967. Lieutenant Zagoskin's travels in Russian America, 1842-1844. The first ethnographic and geographic investigations in the Yukon and Kuskokwim valleys of Alaska. Edited by Henry M. Michael. Arctic Institute of North America, anthropology of the north, translations from Russian sources, no. 7 . Toronto. 


\section{PREFACE TO THE TRANSLATION}

Excerpts from Vasiliy Stepanovich Khromchenko's journal of his voyage in 1822 were published in the periodical Severnyy Arkhiv during the summer and fall of 1824 in seven installments (no. 11, June, pp. 263-276; no. 12, June, pp. 303-314; no. 13/14, July, pp. 38-64; no. 15, August, pp. 119-131; no. 16, August, pp. 177-186; no. 17, September, pp. 235-248; no. 18, September, pp. 297-312). In the interests of continuity, two of these installments have been combined so that there are five sections, or chapters, in the translation which follows. The publication of these excerpts was preceded by an editor's preface (no. 11, June, pp. 254-263), consisting primarily of background information on earlier Russian explorations in the north, trips from Russian ports to Alaska, and round-the-world voyages, which has not been translated. Some information contained in it, however, is incorporated into this preface.

Khromchenko's journal was turned over to Severnyy Arkhiv by the directors of the Russian-American Company. The editors maintained that in publishing excerpts, they omitted only weather observations and changes of the ship's course. It will be obvious to the reader that not all of these were removed. The remainder of the journal is said to have been published in its original form.

In the translation, words appearing in brackets are those of the editor, while words or sentences in parentheses are part of the original text. Where necessary and when known, the present-day spelling of place names and proper names are indicated in brackets next to the original transliteration. Place names which closely approximate modern usage (Pribilov, Nunivok) have been changed to conform with such usage. The names of tribal groupings are spelled as they are in current anthropological literature. All editorial footnotes are numbered and placed at the end of the translation. Footnotes in the original text are indicated by an asterisk and are placed at the bottom of the page where they occur. The first such footnote, following the first paragraph of the journal, contained Muravev's orders to the expedition. It has been omitted and the information 
incorporated into the introduction. Bibliographical references in the editorial footnotes are listed at the end of the translation.

According to an article by B. N. Vishneveskii (Izvestiia akademii nauk SSSR, Seriia geograficheskaia no. 5, September-October, 1953) the original journal of Khromchenko's 1822 explorations was discovered in 1953 among the papers of Kirill T. Khlebnikov (17801838) at Kunger, a central Siberian city northwest of Sverdlovsk. Khlebnikov, a native of Kunger and prominent historian, was associated with the Russian-American Company throughout much of his life. Vishneveskii notes that the manuscript, dated April 23, 1822, consists of 121 pages each 21 by $24 \mathrm{~cm}$. in size. The discovery was made when archival material from Kunger, including the Khlebnikov papers, were transferred to the Molotov Regional State Archive. 


\section{Excerpts From the \\ Journal of Vasiliy Stepanovich Khromchenko \\ On His Voyage of 1822}

Departure from Fort New Archangel [Sitka]. Voyage to Unimak Pass. ${ }^{1}$ First trip to the Pribilof Islands. A search. Our conclusion that the lands which the promyshlennik $i^{2}$ allegedly see from the Pribilof Islands do not in fact exist. Arrival at Hagemeister Island.

In undertaking a description of my second expedition aboard the brig Golounin, ${ }^{3}$ on which last year (1821) I extended my voyage to survey the coasts of northwestern America between Cape Newenham and Norton $\mathrm{Bay}^{4}$ and to gain knowledge of the peoples inhabiting that area, I do not deem it necessary to enlarge much on the enterprise facing me, for it is spelled out sufficiently in the instructions given me by Mr. Muravev.

The ship's equipment and provisions were similar to last year's. I chose my crew personally and to a man they know their business. We laid in five month's supply of the best victuals and we had good astronomical instruments, although unfortunately we did not have the excellent Barodov chronometer I had last year. Further, for greater convenience in making the coastal surveys, the governor of the Russian-American Company ordered the New Archangel office to furnish me five baydarkas ${ }^{5}$ with oarsmen.

Mr. Etolin, who last year commanded the cutter Baranov, now came aboard the Golovnin to take charge of the baydarkas, with which he was to survey the coastal areas that could not be approached by so large a ship as the brig, but which could be approached without danger by baydarka. He collaborated with me in everything during the entire voyage.

By April 25, 1822, we were ready to put to sea, but calms and headwinds kept delaying us. At 5:30 PM on the 26th, following a calm, a light breeze blew up from the $\mathrm{N}$ and we immediately weighed anchor. The fortresses gave us seven ten gun salutes and, parting from our friends and acquaintances, we set our course under full sail. 
As we stood off shore, the wind freshened and our vessel, cutting the smooth sea surface, moved swiftly out of the harbor.

By 8:30 PM we had passed St. Lazarius [Cape Edgecumbe] and Biorka Island, which lies opposite the entrance to Norfolk Sound [Sitka Sound] and, having taken the bearing of the point we had passed (Lat. $56^{\circ} 55^{\prime} \mathrm{N}$, Long. $135^{\circ} 38^{\prime} \mathrm{W}$ ), we began to steer $\mathrm{SW}$. On reaching the open sea, I lay SW by $\mathrm{S}$ to stand off the coast as quickly as possible. The weather continued fair the entire time. The wind, which had shifted from NW to W by $\mathrm{N}$, became gusty and in fear of these gusts we carried little sail.

On May 2, the wind kept shifting, always being light from the NW and steady from ENE; the weather continued excellent till May 6, and we made lunar observations daily. At noon our latitude was $52^{\circ} 52^{\prime} 7^{\prime \prime} \mathrm{N}$, our longitude $162^{\circ} 38^{\prime} \mathrm{W}$. For several days running we saw sea parrots or tufted puffins, kittiwakes, horned puffins, least auklets, and ancient auklets. In the afternoon we were becalmed for several hours, then we had a light breeze from the NNE. From the forecastle and the crosstrees our sailors kept a steady watch for the shoreline which should have appeared but which was obscured by a cloudy sky in that part of the horizon.

At 8:30 PM, through clouds, we caught sight of the northern volcano of Unimak [Island], which was 85 miles* distant. The wind continued steady at NNE and NE, therefore I kept to NNW. By 6:00 AM of the 7th, we were already in Unimak Pass.

As we approached the coast, the wind lulled; the weather continued to be clear and quite warm, although the coasts were completely covered with snow; the mercury at midday rose to $8^{\circ}$ above the freezing point on the Reaumur thermometer $\left[50^{\circ} \mathrm{F}\right]$. For several hours we were without our favorable wind, which had blown alternately from the NNE and NE, for we had come into the lee of an active volcano. Soon we were enveloped by a dense fog and by $7: 00$ PM we could no longer see the coast, which lay $80^{\circ}$ to the NE of us at a distance of 42 or 45 miles.

The next day, as the sun rose, we encountered large flocks of murres and, at times, tufted puffins, horned puffins, and kittiwakes.

At 1:00 PM we sighted St. George Island to W by $\mathrm{S}$ half $\mathrm{W}$, some 20 or 22 miles away; I immediately made straight for it and by $6: 30$ PM I was four miles from its NE extremity. Next, after baydarkas

*I have used Italian miles throughout; there are 60 of these miles to a degree of latitude (Author). 
had been lowered into the water, I set out for shore, bidding Mr. Etolin hold the brig quite close to shore.

We had not yet reached the shore when a dense fog suddenly set in and concealed the brig; this troubled me greatly, for I recalled that in these waters fog often lasts several weeks, and I pondered how much time I should sacrifice here. I was met near shore by the leader of the island, Mr. Netsvetov;* finally, we put ashore in a small bay opposite the settlement and, thus, against my wishes, I had to wait on shore till morning on the 9th when the fog lifted. There was no wind all night and the fog was so thick I could not see 50 sazhens ${ }^{8}$ before me. Finally the fog cleared away as the sun rose and I impatiently awaited the brig, which soon appeared from behind the eastern cape.

Baydarka leader Nets vetov assembled everything I needed and loaded it into a large baydara ${ }^{9}$ which was ready to launch as soon as the brig appeared. Thus equipped, we set out for the ship. On going aboard the brig, I learned that during the night the tide had carried the ship to $\mathrm{SE}$, thus somewhat delaying its arrival.

As we approached the settlement in our brig, we spotted a baydara putting out from shore; I made straight for it and soon we met. At my request, the baydara had brought several barrels of salted fur seal meat and blubber and 15 barrels of fresh sea lion meat. I immediately ordered that everything be unloaded on deck and, taking leave of Netsvetov, I quickly stood off from the island, which was then $25^{\circ} \mathrm{SE}$ of us at a distance of 3 or 4 miles.

When we were about 9 miles from St. George Island the wind rose and we had to take in two reefs on each of the topsails. The ocean depth gradually increased and by noon we were in 45 sazhens of water over a bottom of fine gray sand.

The next day, the 10th, we had intense squalls between NE and $\mathrm{E}$, with rain and fog. We were in the middle of the strait, but could not see either island. After the prolonged good weather we had been having, it seemed very cold to us, although the mercury stood between two and three degrees above freezing $\left[37-39^{\circ} \mathrm{F}\right]$.

At 7:00 AM the fog cleared somewhat and we sighted St. George Island, which was 20 or 25 miles to the south of us. We were in 38 sazhens of water, with a bottom of fine gray sand and shells. In the forenoon we saw bottlenose whales and sea birds: murres, tufted

*The Russian promyshlerniki and the Aleuts ${ }^{6}$ call these leaders baydarshchiki. ${ }^{7}$ 
puffins, horned puffins, Bering's cormorants, and a species of small marsh sandpiper.

At noon our latitude was $57^{\circ} 8^{\prime} \mathrm{N}$, our longitude $169^{\prime} 3^{\prime} \mathrm{W}$; the weather continued absolutely unbearable with rain and wet snow; the ocean depth decreased and when it reached 22 sazhens, I immediately took a different tack. The wind continued to blow in fierce gusts from NNE and NE, which caused high seas and the ship to pitch and roll so much that we could not do a thing, which disturbed us greatly. Finally, at 6:00 PM the fog lifted somewhat and we caught sight of St. Paul Island to the west of us, at a distance of 3 or 4 miles; the ocean depth here was 23 sazhens over a bottom of fine sand.

The storm continued with brief pauses until 4:00 AM of the 11th. As soon as the weather cleared, we could see St. George to SE by E and St. Paul to N by W; St. George was about 33 miles distant, St. Paul, 17 miles. The lead showed 42 sazhens of water and a bottom of fine gray sand with shells.

At first I intended to proceed toward St. Paul to ask the inhabitants for more details about where they sometimes sighted land, but a headwind prevented me from doing so.

Hastening to take advantage of the good weather on the 11 th, I lay to SW under full sail and made 7 to 8 miles an hour. When we were 30 miles SW of St. Paul, I set my course so as to pass directly through the place where the promyshlenniki of the Pribilof Islands sometimes sighted land on a clear day. The wind blew quite fresh from NNW and $\mathrm{N}$ and the weather was alternately clear and cloudy.

Finally, the farther we sailed from the islands of St. Paul and St. George, the more we hoped that we would encounter land soon, but our hope faded for we traveled 60 miles from the Pribilof Islands without encountering any sign of land; we cast our lead without finding bottom at 90 sazhens.

At 10:00 PM it became overcast and I now considered it pointless to sail farther to the SW, for I was firmly convinced that no land could be seen from the Pribilof Islands in that direction; therefore I lay to the ENE.

On May 12 at 6:00 PM the lead showed 38 sazhens over a bottom of fine gray sand. I figured that we had already passed through the strait between St. Paul and St. George, but before returning to Hagemeister Island, ${ }^{10} \mathrm{I}$ had to verify the existence of the land which the inhabitants of St. Paul Island unanimously agreed they could see in 
clear weather from the island's elevation. This land, they claimed, lay in the sea and always in the same direction, to the east. To confirm these stories, I headed for the indicated place. The ocean depth increased from time to time and at midnight was 50 or 51 sazhens.

During the day of May 13, we took various tacks and at night we heaved to (continuing thus until the 15 th), always keeping near the place and in the direction in which land was allegedly sighted from the Pribilof Islands. The weather was cloudy the whole time, but the horizon was so clear we could see for 20 miles in all directions.

Finally, on May 14, having sailed 150 miles to the E of St. Paul Island without encountering any sign of land, I became firmly convinced that no such land exists and that the promyshlenniki of the Pribilofs had seen nothing more than fog, which in these parts fools even the most experienced navigator. At midnight our lead showed 27 sazhens and a bottom of fine gray sand.

On the next day, the 15th, at 3:00 AM, I began to steer $\mathrm{N}$ by $\mathrm{E}$ and the depth eventually decreased. Numerous flocks of sea birds of various kinds kept flying about our ship. We saw one loon among them. At last, at 4:30 AM we sighted a high shoreline to the $\mathrm{E}$ of Cape Newenham, at a distance of 25 or 27 miles. We cast our lead and found 23 sazhens over a bottom of fine gray sand.

Soon a dense fog arose and concealed the shore from us. At noon our latitude was $58^{\circ} 54^{\prime}+\mathrm{N}$ and our longitude was $162^{\circ} 8^{\prime}+\mathrm{W}$, the depth was 25 sazhens with a bottom of coarse sand and stone.

The wet fog continued until 6:00 PM. We surveyed the coastline and made straight for Hagemeister Strait. The wind at the entrance to the strait was completely contrary at $\mathrm{N}$ by $\mathrm{W}$; therefore at first we were not able to round the low spit that extends from Hagemeister Island. After rounding this spit, I sailed $\mathrm{N}$ half $\mathrm{E}$ and $\mathrm{N}$ by $\mathrm{E}$ half E along the strait until 1:30 AM of the 16th, always keeping to the north shore. The depth decreased to 12 sazhens. When we came opposite Aleksandrovskiy Redoubt ${ }^{11}$ I made directly for it; the depth decreased from 5 sazhens to $10 \mathrm{ft}$.

I knew this shoal from last year (1821), at which time I crossed it with the brig, but this time we had low water and the ship's keel scraped bottom lightly several times, however without damage, and by 2:00 AM we were in eight sazhens of water. Finally, at 5:00 AM we dropped anchor a mile off shore in 5 sazhens of water over a bottom of fine gray sand. 
In the forenoon, a three-hatch baydarka approached us from the shore. In it were two Aleuts and a Russian promyshlennik who, on coming aboard, informed me that all was well at Aleksandrovskiy Redoubt. However, he said that the leader had left several days earlier to bring in a cargo of pelts from his former post.

The news of the departure of the leader, Kolmakov, disturbed me greatly, as this would cost us much valuable time, but there was no help for it now.

\section{II}

Our sojourn at Hagemeister Island. Our activities. The Americans ${ }^{12}$ bring us Russian promyshlerniki from their dwellings. Calms and headwinds keep us at the island a long time. Destruction of the settlement and its transport to its former site. Journey northeastward along the strait. A headwind again forces us to ride anchor off the northeast extremity of Hagemeister Island. Our second meeting with Americans and our arrival at the Nushagak River. ${ }^{13}$

To keep from wasting the best time of the year at [Hagemeister] Island, on the second day of our sojourn there I sent out a twohatch baydarka with instructions for Kolmakov that if the baydarka should meet him near the island, he was to come directly to the brig with his full cargo. If the baydarka met him halfway between the Nushagak River and Hagemeister Island, he was to send the cargo back to the Nushagak and report to me posthaste.

Bad weather and rain continued until the 20th. At long last beautiful weather followed. Taking advantage of it, I ordered that all the empty barrels be filled with water, so that we would not have to put in at the Nushagak River for it. Mr. Etolin and I often went ashore to hunt, but although we would spend the entire day at it, we always returned empty handed.

The island was still covered with snow in many places and there was no sign that the grass ever turned green, but the promyshlenniki told me that the winter was not very cold on the island and that there was not very much snow. Our promyshlenniki spent their time snaring partridges, which are very abundant here in winter, and hunting bears. They ate the bear meat as well as the partridge meat. The bears of which the promyshlenniki spoke are terribly timid. All the bears here are red and very large. I saw several skins about 8 ft. long. 
In the forenoon of the 22nd we sighted eight one-hatch baydarkas which made directly for our settlement; I assumed they were bringing Kolmakov, whom I anticipated daily, but I learned that they were Americans who, at Kolmakov's request, had taken in four Russian men and two Russian women for the winter, since the Russians were short of food. Shortly after dropping the Russians off at the settlement, the Americans came to me on the brig. There were six of them, all of medium height; both sides of their mouths and their noses were pierced $;^{14}$ the hair of their head and beards was black and coarse. Their clothing consisted of parkas made of ground squirrel skins. Each of the Americans wore soft, caribou skin boots. They told me they had come from the Tuyugyak [Togiak] River. ${ }^{15}$ Their chief was not with them; they said he was too old to make the trip.

These Americans, we found later, prefer snuff above all else and use a prodigious amount of it. They had as many as 400 beaver pelts with them, but left all their goods on shore, awaiting the arrival of Kolmakov.

The Americans would have stayed aboard our ship longer had they not sighted Kolmakov, who was making directly for the settlement with three baydarkas. The Americans took leave of us and headed for shore.

The language and the baydarkas of the Americans are identical with those of the Kuskokwims and, it would seem, they and the Kuskokwims are of the same race. ${ }^{16}$

Kolmakov came aboard our ship after noon and with him came the same Americans who had been there previously. On stepping aboard, Kolmakov handed me a letter which Mr. Etolin had sent with an Indian [Eskimo] from Goodnews Bay ${ }^{17}$ the previous year (1821), but the messenger had not found me at the island and therefore the letter remained with Kolmakov.

I learned that the Russians whom the Americans had brought with them had spent the winter with a distinguished chief called Panikhpa. This kind old man had come to see Kolmakov the previous autumn solely to learn whether Kolmakov would return soon to the Nushagak River. Kolmakov, trying to avoid a food shortage that winter, had asked chief Panikhpa to take several Russians with him. Panikhpa did not refuse him, but fed and clothed the Russians all winter as he would his own. Furthermore, on their return he gave each of the Russians the finest of gifts, according to his custom, and did not demand any recompense for them. Such a deed is rarely 
encountered among enlightened people, much less among savages who can have very little feeling for and understanding of the wants of their neighbor. This example, however, is not common to all savage peoples of barbarian races, who, instead of helping in need, often turn a deaf ear on the pleas of Europeans even when those Europeans are facing famine.

Panikhpa told Kolmakov that the Kiatagmiut would abandon all trading in furs unless he returned to the earlier settlement.

The settlement on Hagemeister Island had been founded the year before, but only as an experiment and our settlement on the Nushagak River had not been destroyed. The governor, having discovered in my journal and that of Mr. Etolin what trade might be expected from the inhabitants of the Kuskokwim River ${ }^{18}$ and Nunivak Island, ${ }^{19}$ proposed that the Hagemeister Island settlement should be reunited with Aleksandrovskiy Redoubt on the Nushagak River, and commanded me to investigate the advantages and disadvantages of the new settlement and then to effect the transport.

We already knew that the banks of the Nushagak River are very well populated. The upper reaches communicate easily with the headwaters of all the large rivers that empty into the Eastern Ocean [Bering Sea] northward to Norton Sound, and these headwaters abound in beaver. ${ }^{20}$ The neighboring peoples are becoming more and more acquainted with luxuries, and through them the inhabitants of remote places are becoming addicted to trade, but the greatest advantage of the Nushagak River is its proximity to our other settlements.

Hagemeister Island is far from all rivers and has no advantages with respect to trade or supplies, therefore, in the light of the governor's instruction and on the advice of Messers Etolin and Kolmakov, I had no hesitation in moving the settlement back to the Nushagak.

May 23. The weather continued mostly clear until sunset; then the wind veered to the WSW, slackened, and soon we had a dense fog. Mr. Etolin and I were on shore at the time and scarcely made it back to the brig, for the fog was so thick that we could not see more than 20 sazhens in front of us.

May 25. As soon as it became calm in the strait, I ordered Kolmakov to bring his whole crew aboard the brig, which he did quickly, but a headwind, which blew steadily from the E, held us up. 
We had a steady, fresh wind from ENE, followed by a calm that lasted till 7:00 AM on the 26th, then a light breeze blew up from $\mathrm{S}$ and E. We immediately hoisted the anchor and got under way, setting our course NE. I kept close to Hagemeister Island; the wind freshened and we made 5 or 6 miles an hour.

As we moved away from our anchorage and the gully in which our settlement had been, we noted that the height of the island decreased almost imperceptibly and, toward the NE, it ended in a completely flat area at water level. The mountains, which were still snow-covered here and there, were in the SW part of the island. These mountains were all of medium height and not steep. The depth was 7 to 10 sazhens all along this route, 3 or 4 miles off the island, and became deeper farther along the strait.

May 26. On reaching the northeastern tip of the island, we encountered a completely contrary wind and cast anchor in 6 sazhens of water, a mile off shore. We had scarcely begun to ride at anchor when Americans approached us in seven one-hatch baydarkas, some containing one man, some two. These baydarkas were exactly like those we had seen previously. The Americans had set out on a walrus hunt, but on seeing our ship approached us. One of them, named Fedor, who turned out to be Kolmakov's godson, immediately came aboard the brig, and the others followed him. Our ship apparently was the source of much amazement to them; they examined it with great curiosity, some measured its length and breadth in sazhens. Finally, Kolmakov's godson presented me with half a fresh, recently killed caribou and gave his godfather several caribou tongues; then they all departed for the nearby shore.

You cannot imagine how much and with what passion the Americans aboard our ship sniffed ground tobacco. They preferred it even to the necessities of life.

After dinner, Etolin and I went ashore to hunt, but unfortunately we saw nothing but sea gulls and Bering's cormorants. The Aleuts who accompanied us went to the other side of the island where they found dead walruses that had been cast up by the sea and they collected ten large tusks. From one of the walruses, which was a bit fresher than the rest, they cut off the front flippers which they value greatly. The tusks were very large, each weighing 8 to $10 \mathrm{lbs}$.

All night long we had a steady wind between $\mathrm{S}$ and $\mathrm{E}$, with overcast and rain. The next day (May 27) at sunrise, with a light wind from $\mathrm{E}$ by $\mathrm{S},{ }^{21}$ we set sail and, aided by a favorable current, made visible headway; the ocean depth decreased gradually. 
At high noon, the current became contrary and the wind scarcely swelled our sail. Accordingly, to keep the tide from carrying us back whence we had come, we did not shorten our sails but rode on kedge anchor in 6 sazhens of water over a good sandy bottom.

At 3:00 PM a light air blew from the $\mathrm{S}$ and, hoisting our kedge anchor, we headed E. Thereafter we proceeded along the strait which lay $\mathrm{E}$ by $\mathrm{N}$ between the mainland coast and the Walrus Islands, * always holding to the latter. The depth was 10 to 14 sazhens and the bottom was fine gray sand.

We were opposite the second islet, which from a distance appears to be two islands, because of its low-lying isthmus. Captain Cook, who did not see the isthmus, took the island to be two islands separated by a narrow strait. Here we saw 11 baydarkas, which were making their way close to the shore of this island. At 8:30 PM we passed Round Island, which was $22^{\circ}$ to the SW of us at a distance of $21 / 2$ miles..$^{22}$ Now we were close to the mouth of Nushagak River, but a thick fog prevented us from seeing the coast and therefore we had to heave to until 7:00 AM of the 28th. As soon as the fog lifted, I steered E. The depth kept increasing, at first we had 16 sazhens then by noon 17 or 18 sazhens. The bottom consisted of fine gray sand.

May 28. Shortly after noon, from the crosstrees we sighted the left bank of the Nushagak near its mouth and I began to steer $\mathrm{N}$ by W. This bank of the Nushagak was 13 or 14 miles away and our lead showed a depth of more than 17 sazhens.

At about 4:00 PM we passed the low-lying Cape Constantine, ${ }^{23}$ which was 10 or 11 miles SW by W of us; we had a steady wind from the SW with alternating clear and cloudy weather. We sailed NW by $\mathrm{N}$ down the very middle of the fairway. We approached the cape situated on the right side of the mouth of the Nushagak (this cape can be distinguished from the others by the Aglegmiut settlement on it)..$^{24}$ The depth proved to be $31 / 2$ sazhens, so I began to steer NW.

When we came opposite Cape Ekuk [Ekuk Spit], I cast anchor a mile from shore in six sazhens of water, on a silty bottom, for I considered it unwise to sail upstream in the brig, considering the narrowness of the passage.

*These islands are so named for the multitudes of walruses on them. The islands lie almost in a line from Hagemeister Island. There are three of them, not four as Captain Cook stated. 


\section{III}

Meeting with the Aglegmiut and the Kuskowagamiut. Something about these latter. Description of the Aglegmiut in their present state. Their way of life. Their manners and customs. Their clothing and food. Their dwellings, domestic implements, weapons, baydarkas, domestic quadrupeds. Language of the Aglegmiut. A selected glossary of words in their language.

Wishing to leave the Nushagak as soon as possible, on the second day of our stay, early in the morning, we lowered all our rowboats and the large baydarka obtained at Hagemeister Island and immediately loaded aboard them the men and supplies to be transported to Aleksandrovskiy Redoubt.

The weather was splendid the whole time and we had a steady breeze all day from the SW. Although we were some distance from Aleksandrovskiy Redoubt, by sunset we had put everything ashore that was to go ashore with Kolmakov, including the pelts we had aboard for delivery to the New Archangel office. Only some insignificant things belonging to the promyshlenniki who had come with us from Hagemeister Island remained on the brig.

Around midnight the wind fell, which was followed by a calm for several hours, but at sunrise a gentle breeze arose between $\mathrm{S}$ and $\mathrm{E}$ under completely clear skies.

Before noon Aglegmiut and Kuskowagamiut from the settlement visited us in seven one-hatch baydarkas. ${ }^{25}$ The clothing of the Aglegmiut consisted of caribou skin parkas, with the fur side out, while the clothing [parkas] of the Kuskowagamiut was made of ground squirrel skins. They all wore soft boots generally made of caribou skins with the fur side out.

A Kuskowagamiut of rather advanced years, called Kusk, told me that he had just come from the Kuskokwim River where many of his countrymen had told him of the break-up of a small ship above that river. He said that ship's lines and an axe-hewn mast had been found in the fall of 1821 somewhat to the north of the Kuskokwim River.

The Aglegmiut appeared to be very happy that Kolmakov had returned to the Nushagak, saying that now they could start hunting caribou without fear of the Kiatagmiut, who last year had wished to exterminate them all.

The Aglegmiut tribe has a reputation for bravery and fierce barbarity among the peoples who inhabit the northwestern coast of America from Bristol Bay to Norton Sound. 
The constant migration, still remembered by the old people, and constant war with other peoples had made them brave and experienced warriors, but had greatly reduced their numbers. Whereas once they had been dreadful, now they were persecuted and found refuge with Kolmakov. It would be difficult to determine their original homeland.

The Kiatagmiut, out of obedience to Kolmakov, now do no injury to the Aglegmiut, but they cannot forget the barbarity with which the Aglegmiut had formerly treated them. An Aglegmiut named Alinakh told me that the Kiatagmiut have no desire to be reconciled with the Aglegmiut, for they never visit Aglegmiut homes and never seek wives among them.

Kusk and Alinakh presented me with half of a recently killed caribou and several caribou tongues.

The Aglegmiut whom we saw were of medium height, quite stately, with a manly gait, regular facial features, and with coarse black hair and beards; they, like all the inhabitants of northwestern America, pierce their nose and both sides of their mouth and put bones, stones, or sky-blue glass beads in the openings.

The men and women wear caribou skin parkas with the fur side out. The women wear a kind of trousers together with otter skin or caribou skin boots.

The Aglegmiut lead exactly the same kind of life as do all the peoples inhabiting Kenai Gulf [Cook Inlet], Kodiak Island, and the lands to the north of them. It is difficult to determine the temper of the oppressed Aglegmiut. They now seem quite peaceful, but this may be involuntary. Other peoples tell many stories of their obstinancy and barbarity.

They are of the shaman faith, for they believe in sorcerers or shamans. They fear devils, to whom they always take offerings at their performances or assemblies. ${ }^{26}$ They do not grasp the concept of One Supreme Being and do not even have a name for him; rather they call their various gods and idols by different names.

Their food for the most part consists of products of the sea; however, in spring and fall they hunt caribou and dry the meat in the sun, as they do fish, and they use the skin for clothing and footwear. They take many belugas [white whales] and seals and trade the skins and blubber to the neighboring Indians [Eskimos] for beaver and otter skins. ${ }^{27}$ 
Their dwellings are similar in all respects to the Aleutian mud huts and from a distance look like hillocks; they have a hole in the roof for the escape of smoke. ${ }^{28}$

The domestic implements consist of wooden boxes, buckets, cups, and platters and pans of different sizes. All these are made artfully and skillfully. They make their pots exclusively of clay and in them cook mostly fatty foods, with the result that they are greasy and generally not very clean.

The Aglegmiut have many spears and bows and arrows, which they apparently use for sea and land hunting. Their baydaras and baydarkas are identical to those of all the peoples of northwestern America. The Aglegmiut, in general, honor their best huntsmen, but their present situation even affects their hunting, for they have begun to neglect it owing to their constant peril.

The Aglegmiut have dogs, which they use as a means of transportation in winter. For this purpose they have large and small sleds, exactly like the Kamchatka sleds.

The language of the Aglegmiut resembles the Konyag language in all respects, as can be seen from a comparison of the words I have collected..$^{29}$

VOCABULARY ${ }^{30}$

$\begin{array}{lll} & \text { Konyag } & \text { Aglegmiut } \\ \text { Sky } & \text { Kilyak } & \text { Chyslyamok } \\ \text { Moon } & \text { Iyalok } & \text { Ialuk } \\ \text { Sun } & \text { Machak } & \text { Nukhslyamuk } \\ \text { Stars } & \text { Ag-yat } & \text { Avvyzyt } \\ \text { Day } & \text { Aganyak } & \text { Agynyk } \\ \text { Night } & \text { Unuk } & \text { Unuk } \\ \text { Air } & \text { Tuplekhtok } & \text { Smokhtok } \\ \text { Clouds } & \text { Amykhliok } & \text { Amygalyuk } \\ \text { Water } & \text { Tanak } & \text { Magamyk } \\ \text { Sea } & \text { Iman } & \text { Tagazemyk } \\ \text { Island } & \text { Kikikhtak } & \text { Kikikhtak } \\ \text { Shore } & \text { Nuna } & \text { Chanik } \\ \text { Lake } & \text { Nannoak } & \text { Nanuvak } \\ \text { River } & \text { Kvik } & \text { Kviygat } \\ \text { Forest } & \text { Napat } & \text { Napa } \\ \text { Ice } & \text { Chikuk } & \text { Chiku } \\ \text { Cold } & \text { Pachnikhtok } & \text { Nyglyamyk } \\ \text { Frost } & \text { Nynlekhtok } & \text { Nyglyavyk } \\ \text { Snow } & \text { Anyu } & \text { Kapikachok } \\ \text { Heat } & \text { Uknikhtok } & \text { Kalyatok } \\ \text { Earth [Land] } & \text { Nuna } & \text { Nuna } \\ \text { Mountain } & \text { Inek } & \text { Inrrek } \\ \text { Grass } & \text { Ibyit } & \text { Ibyglit } \\ \text { Sand } & \text { Kagvyyak } & \text { Kavyzyak } \\ \text { Stone } & \text { Yamak } & \text { Simmak } \\ \text { Person } & \text { Syuk } & \text { Syuk }\end{array}$




\begin{tabular}{|c|c|c|}
\hline & Konyag & Aglegmiut \\
\hline Man & Nukalkhpyak & Nugaspakh \\
\hline Woman & Aganik & Agnik \\
\hline Old Man & Alemun & Inuslyugak \\
\hline Old Woman & & Aganyskuak \\
\hline Child & Uzvilkhak & Taniukhagak \\
\hline Girl & Aganak & Aganat \\
\hline Life & Unukhak & Unovok \\
\hline Death & Tukan & Tukan \\
\hline Animal & Univalkhan & Nuvelrrek \\
\hline Food & Nyuka & Noka \\
\hline Bird & Sakitk & Chagov-lik \\
\hline Father & Atana & Atavyt \\
\hline Mother & Anana & Aynavyt \\
\hline Son & Avakutan & Irreniyka \\
\hline Wife & Nuliga & Numaka \\
\hline Daughter & Paniga & Panieka \\
\hline Brother & Diokha & Uryuachaka \\
\hline Sister & Alka & Alkaka \\
\hline Friend & Kunuk-naka & Kunukaka \\
\hline Scoundrel & Pinichuga & Avak \\
\hline Eye & Inalak & Ina \\
\hline Nose & Unustok & Knaka \\
\hline Mouth & Kanyk & Kanka \\
\hline Teeth & Khutyt & Kautka \\
\hline Tongue [Language] & Umoka & Umoka \\
\hline Arms & Aykhey & Aykhanka \\
\hline Legs & Itet & Ityganka \\
\hline Iron & Chevyk & Chevyka \\
\hline Trade bead & Chunayakhpak & Chumagala \\
\hline Yurt [Tent or house] & Cheklioak & $\mathrm{Na}$ \\
\hline Rain & Kityk & Ibyzyuk \\
\hline Fog & Taytuk & Taytuk \\
\hline White & Kash-gli & Kashykhtok \\
\hline Red & Kavygli & Kavykhtok \\
\hline Black & Tumunuk & Talkhtok \\
\hline Dark-blue & & Chumykhtok \\
\hline Wet & Michumak & Chumuk \\
\hline Thin & Amitok & Chanygatok \\
\hline Thick [fat] & Chinpuk & Chanuk \\
\hline Much, many & Amaliktut & Amylskhtut \\
\hline Few, little & Ikitut & Ikkhatok \\
\hline Fine, good! & Asikhtok & Asikhtok \\
\hline Badly, It is bad & Asitok & Asitok \\
\hline Sea water & Tag-yuk & Taga-zyuk \\
\hline River water & Tanak & Machamyk \\
\hline Bay & Na-nognak & Nanuvakgnykh \\
\hline Fox & Kafeyak & Kavsyak \\
\hline Beaver & Akhna & Pamokstok \\
\hline Ears & Unyuit & Chutit \\
\hline Hair & Nuyat & Nuêt \\
\hline Right hand & Talekhti & Aygat \\
\hline Left hand & Eksyuka & Iksyukha \\
\hline Baydarka & Kayak & Pukhtan \\
\hline Oar [Paddle] & Chakspik & Anuagok \\
\hline Beluga & Aziyagnak & Chtok \\
\hline Beaver stream & Amokatkhan & Amokitkhan \\
\hline Fire & Knyk & Knyk \\
\hline Smoke & Puiok & Pudiok \\
\hline Clear weather & Asitgok & Anuksyakhtok \\
\hline Poor weather & & Chelyapatok \\
\hline North & Vasyak & Kmovagak \\
\hline
\end{tabular}




$\begin{array}{lll} & \text { Konyag } & \text { Aglegmiut } \\ \text { South } & \text { Vakak } & \text { Nygak } \\ \text { East } & \text { Unalyak } & \text { Unilyak } \\ \text { West } & \text { Tlyanek } & \text { Kanyakhtok } \\ \text { Evening } & \text { Akvaakhtok } & \text { Akvavok } \\ \text { Morning } & \text { Unnok } & \text { Unuk } \\ \text { Whale } & \text { Anok } & \text { Agabok } \\ \text { Walrus } & \text { Azyuk } & \text { Kchikhpak } \\ \text { Strong } & \text { Tkhak } & \text { Tykhnypak } \\ \text { Weak } & \text { Unyuneytok } & \text { Ktyunonek } \\ \text { Dry } & \text { Kinygnak } & \text { Kinagokhta } \\ \text { Wet } & \text { Michumuk } & \text { Chumuk } \\ \text { Sky-blue } & \text { Chunikhtok } & \text { Chumagalyukhtok } \\ \text { Knee } & \text { Chitkok } & \text { Chitkok } \\ \text { Forehead } & \text { Kakygmiok } & \text { Pyatyk } \\ \text { Beard } & \text { Timmo } & \text { Tammo } \\ \text { Nostrils } & \text { Pachakhvak } & \text { Pachagvok } \\ \text { Dog } & \text { Keymukhta } & \text { Keymukhta } \\ \text { Red Fox } & \text { Kaviyak-Kavtikin } & \text { Kaviyak-Kavakhtok } \\ \text { Black Fox } & \text { Tingitkak } & \text { Talkhtok } \\ \text { White Fox } & \text { Kitykhli } & \text { Katagali } \\ \text { Wolf } & \text { Kagina } & \text { Chuvutkha } \\ \text { Bear } & \text { Navgiak } & \text { Navunak } \\ \text { Sweetly, It is sweet } & \text { Kakkhtok } & \text { Nakniyatok } \\ \text { Far, It is far } & \text { Yankhtok } & \text { Zyazikhtok } \\ \text { Near, It is near } & \text { Kanytok } & \text { Kanetok } \\ \text { Here } & \text { Tavana } & \text { Tavaa } \\ \text { There } & \text { Iyani } & \text { Tavantok } \\ \text { I } & \text { Khvy } & \text { Khvu-i } \\ \text { Thou } & \text { Lpyt } & \text { Lspyt } \\ \text { He } & \text { Um } & \text { Una } \\ \text { She } & \text { Um } & \text { Una-Khona } \\ \text { Come here! } & \text { Taykhut } & \text { Ta-ay } \\ \text { Go away } & \text { Ani-ata } & \text { A-zy } \\ \text { To sleep } & \text { Kivayatuk } & \text { Kavayatok } \\ & & \end{array}$

\section{COUNTING}

$\begin{array}{lll}\text { One } & \text { Alkhamiok } & \text { Atavchik } \\ \text { Two } & \text { Malluk } & \text { Ay-pa } \\ \text { Three } & \text { Pinayuon } & \text { Pin-izok } \\ \text { Four } & \text { Staman } & \text { Chtalisk } \\ \text { Five } & \text { Talimik } & \text { Talimik } \\ \text { Six } & \text { Akhokelin } & \text { Agavanik } \\ \text { Seven } & \text { Malkhoglin } & \text { Ay-pak } \\ \text { Ten } & \text { Kulin } & \text { Kulin } \\ \text { Twenty } & \text { Svinak } & \text { Chuinak } \\ \text { Forty } & \text { Svinak malguk } & \text { Chuinak manyayuk } \\ \text { Summer } & \text { Kyuyak } & \text { Kiek } \\ \text { Spring } & \text { Upinkhkak } & \text { Upynykhak } \\ \text { Winter } & \text { Uksyuk } & \text { Uksyuk } \\ \text { Fall } & \text { Uksyuak } & \text { Uksyugmokhtok }\end{array}$

I had intended to leave the Nushagak River as soon as the unloading and ship's work were done, but headwinds and a dense fog detained me until June 9. Meanwhile, Mr. Etolin and I often went hunting and since there was much game here, we not only had fresh 
meat every day for the table, but we had meat for several weeks at sea. Kolmakov often furnished us with fresh gull eggs and caribou meat. However, the only fish in the Nushagak River was the loach. ${ }^{31}$

\section{IV}

We continue to sail westward. Renewed search. Our conclusion that no land exists to the east of the Pribilof Islands. We sail northward. Arrival at Nunivak Island. We ride at anchor on the south side of that island. Encounter with the inhabitants of Nunivak Island. We round the island from the SE. Description of the strait and the surrounding coasts. This is called Cook Strait [Etolin Strait]. Survey of the coasts lying north of Cape Vancouver. We sail in shallow water along the northwest coast of America and drop anchor off the northeastern part of Stuart or Kikhtakhpak Island.

On June 9, at 3:30 AM, with a steady wind from the NE, we departed the Nushagak River. During our stay there, we made many observations of the latitude of our anchorage and found it to be, on an average, $57^{\circ} 40^{\prime} 53^{\prime \prime} \mathrm{N}$, and we determined the mean longitude, according to the two lunar observations I made before and after noon, as $158^{\circ} 34^{\prime} 31^{\prime \prime} \mathrm{W}$.

The wind veered through $\mathrm{E}$ to $\mathrm{E}$ by $\mathrm{S}$; in the forenoon the wind blew quite fresh with overcast, but then the wind fell and soon we had clear weather.

At 9:00 PM, being $50^{\circ} 30^{\prime}$ to the SE and 18 to 19 miles from the SW end of Hagemeister Island, I again began to head SW, straight toward the place where I had conducted my search the month before. The ocean depth increased from time to time as we moved out to sea.

On the 10th, at 2:00 AM, we sighted Cape Newenham $30^{\circ}$ to the NW at a distance of 36 miles; we cast our lead and found 26 sazhens over a bottom of fine gray sand.

Calm and near calm continued till 11:00 AM of the 12th, after which we had a steady breeze from SSE. Every day we caught cod by hook and line; in fact we encountered cod quite often here. Some of them were quite large and none was smaller than 25 to 30 pounds.

At 9:00 PM it became overcast and soon we had rain. At 9:30 PM we were at latitude $57^{\circ} 16^{\prime} \mathrm{N}$ and longitude $167^{\circ} 53^{\prime} \mathrm{W}$, more than two degrees of longitude to the east of St. Paul Island. On visiting this area a second time, I became firmly convinced that there is no land to the $\mathrm{NE}$ and $\mathrm{E}$ of the Pribilof Islands (land allegedly visible from the islands of St. Paul and St. George). 
With each passing hour the wind became fresher, while alternating overcast and fog obscured the horizon. Therefore, to keep from wasting time, I decided to make straight for Nunivak Island and from there, as soon as the weather permitted, to complete my description of the northwest coast of America from Cape Vancouver to Stuart Island. We were in 45 sazhens of water over a bottom of the finest sand. We tacked and steered $\mathrm{N}$ half $\mathrm{W}$.

All night long the wind was quite fresh at SSE with alternating foggy, wet, and overcast weather. Under sails and foresail we made 8 or 9 miles an hour. The depth gradually decreased and at 9:00 AM was 26 or 25 sazhens.

Around noon the wind lulled, but the thick fog continued unabated and since we reckoned we were quite close to Nunivak, we proceeded under light sail on various tacks, in depths of 23 to 18 sazhens, often heaving to. The crew spent the whole day catching cod, which appeared here very often, and we caught so many that I ordered the surplus to be salted in a special barrel.

Dense fog, alternating with overcast, continued till 6:00 AM of the 17th, then a light breeze came up from the NW, the fog immediately lifted, and we sighted Nunivak Island, which was between $\mathrm{N}$ by $\mathrm{W}$ and $\mathrm{NE}$ at a distance of 12 or 15 miles. We cast the lead and found 171/2 sazhens of water and a sandy bottom.

I made straight for the cape which projects farthest south ${ }^{32}$ and having reached it, I intended to sail along the island toward the strait. ${ }^{33}$ A light air blew from NW by $\mathrm{N}$ and $\mathrm{NW}$ by $\mathrm{W}$ with alternating clear and cloudy weather. Taking advantage of it, by 9:00 PM we were at $59^{\circ} 47^{\prime} \mathrm{N}$ and $166^{\circ} 25^{\prime}+\mathrm{W}$, with a variation of the needle of $22^{\circ} 35^{\prime} \mathrm{E}$; we were $45^{\circ} \mathrm{SW}$ of the aforementioned cape, at an estimated distance of about 7 miles. The lead showed 16 sazhens over a bottom of fine gray sand. The wind quickly died died down and by 11:00 PM we were completely becalmed.

The calm, sometimes with slight breezes between $\mathrm{N}$ and $\mathrm{W}$, continued until the morning of the 18th; as soon as a light breeze sprang up from $\mathrm{N}$ by $\mathrm{E}$, I began to head for the southern tip of Nunivak Island.

Soon inhabitants of Nunivak Island approached us in about 25 baydarkas. ${ }^{34}$ The baydarkas were all of the one-hatch type, some containing one, some two islanders; on approaching us, each of them shouted very loudly and probably gave some greeting, as do all Americans on their first encounter with Europeans: The words $a y$-ay and $y u-y u-y u$ were always heard at the end of each melodic greeting. 


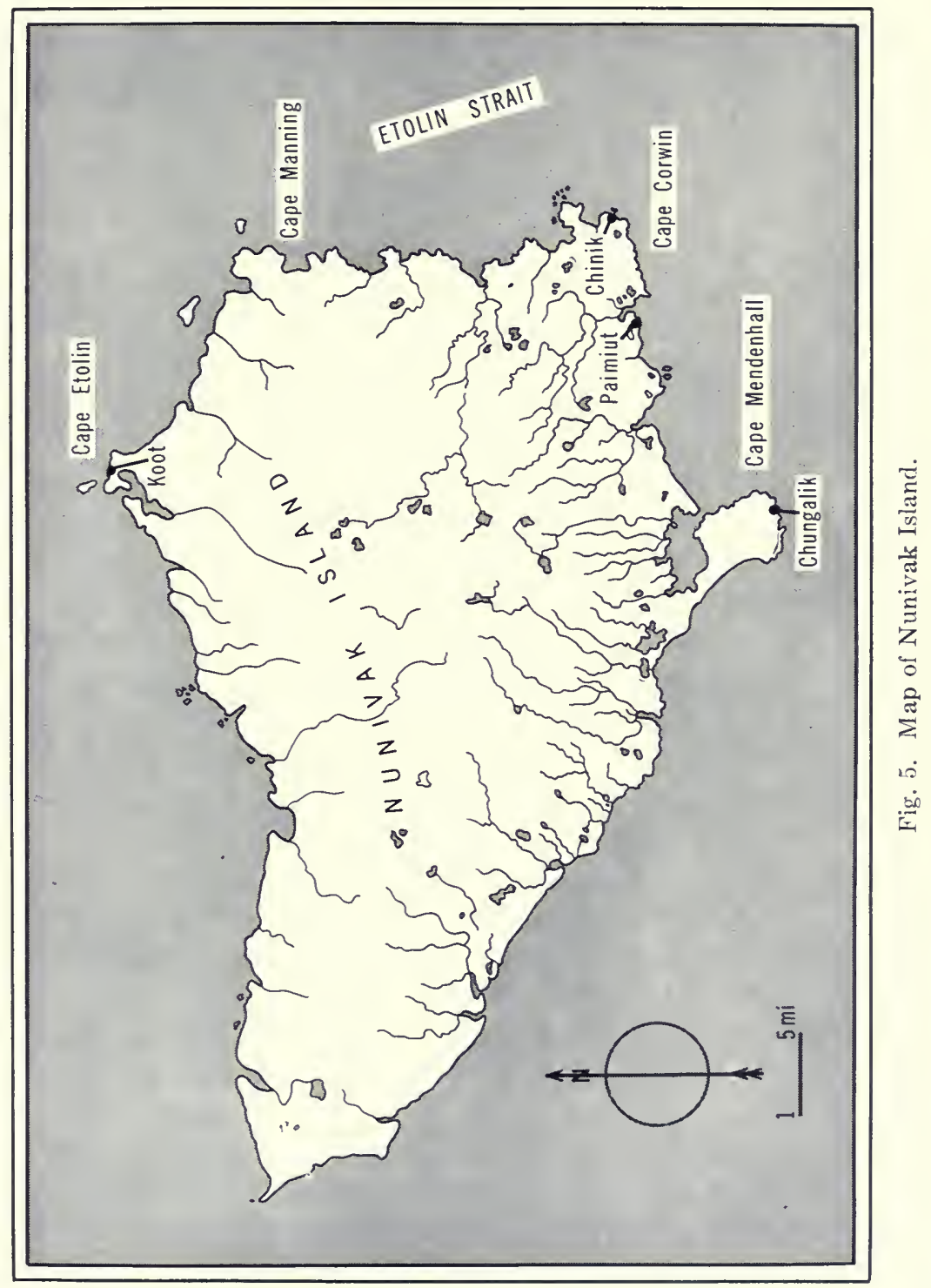


Among the islanders was the chief Ayagakak, to whom Etolin had given a silver medal the year before. He came aboard in full regalia and turning to $\mathrm{Mr}$. Etolin said that he had strictly observed all the instructions given him in consideration of the medal. One could see that everything that Etolin had given him had been carefully preserved; not even the sheet of paper with the notation of the year, month, and day that the cutter Baranov had visited the island had been damaged in the slightest.

Ayagakak, judging by his hair, which was completely white, must have been very, very old, but despite this he was agile, hale, and hearty. I invited him into my cabin and he followed me without the slightest objection and was quite amazed by whatever caught his eye; the only thing that seemed strange to us was that the old man would eat nothing we offered him, probably because of some prejudice of his, or perhaps our food did not look very tasty to him.

The Nunivak Islanders on our ship were generally of medium height, slight, with regular facial features, and black coarse hair. They were quite stately and had a proud walk. Each had his nose pierced and his lower lip pierced in three places, and in these spaces he placed either stones, nicely worked bones, or a glass bead. According to their stories, they obtained these beads through trade with the Kuskowagamiut..$^{35}$

The Nunivak Islanders also cut their ears through and placed nicely worked bone earrings in the slits.

Their clothing consisted of fox and muskrat parkas, which were generally sewn with the fur side out, and over this they wore waterproof coats made from the intestines of sea animals; these coats protect them from the damp weather.

The Nunivak Islanders offered us white fox, red fox, caribou, and muskrat skins for hoop iron, Aleut hatchets, sky-blue bangles, and trade beads.

We sailed as soon as a light breeze came up from the N, and I lay along the coast to the ENE. Chief Ayagakak and some of the islanders went straight to the nearest shore, while the others followed us.

About 4:00 PM we approached the settlement of Chungalik ${ }^{36}$ which lies on the eastern side of the southern end of the island and we dropped anchor in 15 sazhens of water over a bottom of coarse sand. The settlement Chungalik was $65^{\circ} \mathrm{NW}$ of us at a distance 
of $1 \frac{1}{2}$ miles; the southern end of Nunivak Island was $76^{\circ} \mathrm{SW}$ of us at a distance of 4 miles.

The Nunivak Islanders who followed our ship fell behind because of our great speed, but soon after we had cast anchor others, whom we did not know, approached us from the settlement. Seeing that they approached our ship cautiously, I ordered my interpreter to invite them aboard, and to impress upon them our friendly intention. However, they kept their distance from us. Shortly thereafter, an islander arrived from shore who, we were to learn, was called Tammlokh. On his neck he wore a bronze medal with a replica of the portrait of His Majesty the Emperor Aleksandr on one side and on the other side the inscription: The sloops Otkrytie and Blagonamerennyy and the notation 1819 .

I learned subsequently that Tammlokh had been hunting on the western end of the island when he received the medal from a large ship. Tommlokh also told us that several men from the ship had disembarked on the island, but stayed only briefly and returned to the ship. Tammlokh did not know where the ship went, for he did not see it the next day.

Knowing that Captain Vasilev had been at the western end of Nunivak Island last year (1821), we knew whence Tammlokh had got his medal. ${ }^{37}$

For a long while the islanders would not come aboard, but having witnessed our treatment of Tammlokh, they finally came alongside the brig and then on deck. They were exactly like the people we had seen earlier on the western side of the southern end of the island. Many of them had some European artifacts, among which I saw a printed linen kerchief, which one must assume came from the cutter Baranov.

Soon trading began and the islanders traded us red fox skins, of which they seemed to have very few and those of the lowest quality, and bows and arrows for iron nails, hoop iron, and trade beads.

The Nunivak baydarkas are exactly like those of the Aleuts and are armed with walrus teeth [ivory] lances and arrows that are well and skillfully made. ${ }^{38}$

The bartering continued till sunset, then one by one the Nunivak Islanders departed. The sound of the long reception speech continued to the settlement itself. On disembarking, the islanders lit campfires at various points and conversed loudly. 
The weather continued to be clear all through the night and since the NW wind was very light, I decided to stay until morning. The next day, many of the islanders, in baydarkas, surrounded our brig, including Chief Ayagakak, who came aboard and presented me with two red foxes. On my part, I presented him various baubles and several leaves of tobacco, but Ayagakak would not accept them, probably because he did not know their purpose. The islanders again exchanged bows, arrows, wooden vessels, and various walrus teeth [ivory] arifacts for hoop iron and some wretched rusty nails. There was not a single woman among them. As I mentioned earlier, the baydarkas contained either one or two men.

The aforementioned chief, although revered, does not seem to have any authority, for he wears the same kind of clothing and ornaments as the lowliest of his subjects and his subjects do not respect his commands. For the most part it would appear that they follow only [his] advice and often laugh at him; from this one may conclude that if their chiefs do govern them it is not by sovereign power but by experience and intelligence..$^{39}$

Wishing to reach the strait between the mainland and Nunivak Island as soon as possible, we set sail under a light west wind. Apparently the islanders greatly regretted our early departure and each of them assured us that we would find nothing in the strait and that it would be worse for the ship there than at Chungalik. The weather continued alternately cloudy with overcast, the wind blew along the island and I kept the brig as close to the island as I could, the better to see the windings of the coastline and to determine the ocean depths along the island.

We dropped anchor 3 miles off shore at 4:00 PM, after having rounded the SE cape of the island. The Nunivak Islanders put out from shore in 20 baydarkas and made for our brig posthaste; however, without waiting for them, Mr. Etolin and I set out for the settlement of Chinik. ${ }^{40}$ The islanders, noting this, immediately turned and accompanied us to the settlement. We landed directly opposite the village itself in a small sandy inlet, the north side of which was covered with a number of boulders almost reaching shore, while on the south side of the bay there was a stone bar placed in such a way that there were no breakers whatsoever at the place we landed.

All the islanders were set in motion by our arrival at the settlement; each of them hurried into his hut and quickly returned with various products of his skill. Bows, arrows, wooden vessels, and the 
like served to start the trading, which then followed the established pattern.

While the barter was in progress, I walked some distance from the settlement toward the interior of the island, but I had to return for I encountered a wet tundra area. En route I saw a fresh grave, around which stood various objects and some baydarka frames. The weapons of war, however, lay above the grave itself and were not yet damaged in the least. ${ }^{41}$ Later I visited several of the huts, which are exactly like those of the Aglegmiut. In one such dwelling I found an iron adze with a short wooden halve which still had a brand on it, but it was difficult to determine the origin of the adze from this marking. I bought the adze from the islander to whom it had belonged, Chanikhak, who said that he had obtained it from the Kuskowagamiut. In turn, they probably got it from Kolmakov, for we saw here several cloth objects of Russian make, hastily and poorly done, which the Nunivak Islanders had obtained from the Kuskowagamiut, and they, undoubtedly, from Kolmakov.

The inhabitants of Nunivak Island generally are of medium height and are very well built; they have quite regular features which reveal their good nature that is also evidenced by their kind treatment of foreigners. However, their stupidity and careless indifference appears everywhere and in everything. The color of their skin, despite their lack of cleanliness and the soot, differs little from a European's. We saw no freaks among them; their bodies are spare but well made.

In general, the women are not very pretty. Their faces are flat, their eyes small, narrow, and black, their hair is straight, long, and coarse. They plait their hair into two or four braids over their temples and interweave blue beads or strands of caribou fur in them, but these ornaments are tasteless and poor. Their skin is white and they are very fat, short, and, in general, clumsy. They have a heavy gait, and even the young ones do not walk with a free step, but waddle, as it were. Their sooty and greasy caribou skin coats cover their charms and deficiencies. They appear to be more modest than the women of the Pacific islands, for they are humble, shy, and taciturn, and they adorn only their arms, not including the hands, with patterns. The iron and copper rings which they wear on their wrists are their principal ornament. Their handwork is crude, displaying neither the painstaking work or the taste of the Aleut women.

We found the way of life and the customs of the Nunivak Islanders to be completely like those of the Aglegmiut and even those 
of other peoples northward to Norton Sound and beyond. The steam baths here are constructed exactly the same way as those of the Aglegmiut and the Aleuts and apparently serve the same purpose. ${ }^{42}$

I can say nothing more about this gentle people, for our stay on the island was short.

In addition to the islanders, we saw four men and four women who had recently come from the mainland coast. The Nunivak Islanders called them Nunipaegmiut. ${ }^{43}$ An old man, through his stories and a drawing, acquainted me with the coasts that I would soon be describing. Probably this American had often passed along the coast lying between the Kuskokwim River and Norton Sound and, therefore, was thoroughly acquainted with its situation, for when he would draw a coastline in the sand, not one of his companions would contradict him in the slightest.

At 10:00 PM we returned to the ship, a fresh wind blew from the SW and WSW and the weather was cloudy and rainy.

I proposed that we fill the empty barrels with water here, but since we stood at anchor some distance off shore, we had to move in closer. The wind at SW and W was quite fresh and the weather was rainy and overcast. At 11:00 AM of the 21st we got under sail. We had to work hard to retrieve the anchor, for it was so caught up on a rock that we could scarcely lift it. When we finally did retrieve it, we saw that it was bent and did not use it subsequently.

By 9:00 PM, after taking several tacks, we moved into 8 sazhens of water. Shortly after casting anchor, I had all our rowboats lowered and the empty barrels loaded into them; then I accompanied them to the river in a three-hatch baydarka. We did not reach the river until midnight, at which time the water level was so low that it was very difficult for the rowboats to enter the river.

As the workers filled the barrels, I took the baydarka to the left side of the river, right up to a dwelling which proved to be deserted. However, we did see some fishing implements and caribou antlers scattered about the ground. There were also some broken pots and wooden bowls, many fresh shavings, and a fire which had just gone out. All this clearly indicated that people had recently used this domicile.

As the water increased in the river, I strolled about the island and saw longspurs, partridges, hazel grouse, and a kind of small snipe called the redcrop. I also heard the cry of geese and cranes. The 
Aleuts, who went farther inland, said they saw caribou and, on returning downstream, they found a dead, but still fresh, fish of the salmon family. As soon as the water had risen, I sent the boats back to the brig, while I directed the baydarka toward the bare islets situated on the left side of the river mouth.

The river from which we took our water is not terribly wide. It is not more than 100 sazhens wide at the mouth and the depth at the entrance is no more than a sazhen. The left bank is craggy and, in general, consists of burnt [volcanic] rock, while the right bank is gently sloping and sandy for the most part. The river runs SSW from its mouth; the bottom is stony and the water is pure. The river consists first of two streamlets which join before entering the sea; at high water this junction can be approached by rowboat. ${ }^{44}$

On reaching the islets, I stepped out on them; my oarsmen collected several seagull eggs and then we returned to the brig. The islets, three in number, lie along the strait and are no more than $11 / 2$ miles from Nunivak Island. These islets, like the coast of Nunivak itself, consists of burnt rock.* A glance at the coast of Nunivak Island and its crumbling mountain will convince the viewer that this country once experienced an earthquake resulting from a subterranean fire. ${ }^{45}$

When I boarded the ship at 6:00 AM on the 22nd, the water was already stored in the hold and all the rowboats had been raised, so that we set sail immediately. A steady wind blew from the S and the weather was variable. I first steered ENE directly toward Cape Avinof. ${ }^{46}$ The depth increased from 8 to 15 sazhens, but the bottom alternated very frequently between burnt rock and fine sand.

At noon, observation showed our latitude to be $60^{\circ} 2^{\prime} 10^{\prime \prime} \mathrm{N}$ and

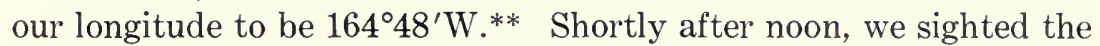
shoreline to the right and, in order to approach it, I steered slightly into the wind. By 1:00 PM, we were in 3 sazhens of turbid water.

The American coast here is very low. We were almost upon it, but could not see it and what I have called Cape Avinof is not really a cape, but an elevation or a small isolated mountain fairly far from the sea.

At 3:00 PM we made straight for Cape Vancouver. ${ }^{47}$ The depth did not exceed 9 or 10 sazhens and we had a steady wind between $\mathrm{S}$

*Some travelers have called them lava or volcanic rock, but I call them burnt rocks, because they look very much like the cinders one finds in blacksmith forges.

${ }^{* *}$ Subsequently we derived this latitude by calculation between the Nushagak River and Cape Count Rumyantsov [Cape Romanzof]. 
and E under a cloudy sky and overcast. Finally, around 4:00 PM, the depth again decreased to 5 sazhens and soon we sighted breakers to the ESE at a distance of about $11 / 2$ half miles. I immediately brought the ship around to the WNW and sailed thus until 6:00 PM.

We passed WSW of Cape Vancouver at a distance of about 2 miles in 9 sazhens of water over a bottom of pure sand. The wind shifted from SE through E to ENE and gusted and we had overcast and rain. I made a port tack close to the wind and tried to keep the shoreline in sight; the ocean depth decreased from time to time. On the north side of Cape Vancouver we saw many bays which ran some distance into the land. I wanted very much to explore them, but could not because of the shallow water.

As we made our way through the strait between Nunivak Island and the mainland, we had clear skies and were able to get a very good look at the island's coastline. The northeast cape of the island terminates in low-lying land and the coast there turns $W$, then continues WSW. We could see snow-covered mountains in the island's interior; the mountains were all of medium height and not very steep.

Cape Vancouver is craggy and a chain of mountains stretches inland from it. To the south, the cape ends in a cliff, while to the east the coast gradually descends until it is not even a foot above sea level. Therefore, one can get close to it without seeing it. Farther on, only the elevation of Cape Avinof is visible.

The strait which separates Nunivak Island from the mainland is 37 miles long and 17 miles wide and runs NNW-SSE. In the very middle, the strait is 10,13 , and 15 sazhens deep; close to the island the bottom is stony with sand, while in the middle of the strait it is pure sand and in case of need one may ride at anchor here. This is called Cook Strait [Etolin Strait] in honor of the famous Captain Cook, who came very close to these parts in 1778 , but shallow water and fog prevented him from sighting this coast and thus discovering Nunivak Island.

At 6:00 AM of the 23rd, the wind shifted to the $\mathrm{NNE}^{48}$ and lulled and shortly thereafter the weather cleared a little. We sighted the northeastern tip of Nunivak Island, ${ }^{49}$ which is all the more evident for the two low mounds on it.

Fog set in again in the afternoon and was so thick that we could not see more than 50 sazhens before us. Thus I lost my chance to survey the north side of Nunivak Island, but I did not feel justified in waiting until the fog cleared and the wind allowed us to approach that coast. 
A gentle breeze blew up from the $\mathrm{W}$ under cloudy skies. A near calm soon ensued, followed by a total calm that lasted until 8:00 PM of the 25th. Then a light air rose at SW and we lay to the ENE. Cape Romanzof was $50^{\circ} \mathrm{NE}$ of us at a distance of 25 miles. We were in 15 sazhens of water. When we began to have overcast, I tacked and stood out from shore. We did not wish to lose sight of land again, so to keep close to it I shortened the sails and kept to W and WSW all night long.

At 6:00 PM we sighted the low coast to the south of Cape Romanzof which stretches NNW-ENE for about 12 miles. We were no more than 7 miles from it and our lead showed the depth to be $4 \frac{1}{2}$ sazhens. I sailed ESE along the coast even though we were moving into ever shallower water. At 8:00 PM, when we were in just 4 sazhens of water, we saw a chain of fairly high, snow-covered mountains which were $64^{\circ} \mathrm{SE}$ of us at a distance of about 30 miles. The lowlying coast, which we always kept in sight, was scarcely visible and trended directly toward the snowy mountain chain.

From 9:00 to 11:00 PM we ran along the coast SE by E and SE. Finally, having convinced myself that this mountain ridge adjoins Cape Vancouver and that the low-lying coast extending from Cape Romanzof is a continuation of Cape Vancouver, I hastened to withdraw from the coastline for I feared that we were in for a gale. ${ }^{50}$

My instructions were to describe the coastline between Cape Romanzof and Stuart Island and, having surveyed this expanse, to sail along the northwest coast of America to Cape Prince of Wales and then into Bering Strait, as time allowed. Therefore, I tried to get as close as possible to Cape Romanzof to begin my description there, but the very light breeze we had between $\mathrm{S}$ and $\mathrm{E}$ afforded us little cooperation in this endeavor.

At 9:00 PM our latitude was $61^{\circ} 51^{\prime} \mathrm{N}$ and our longitude was $166^{\circ} 34^{\prime}+\mathrm{W}$, the variation of the needle was $23^{\circ} 3^{\prime} \mathrm{E}$. During the night of the 29th the wind lulled and we had a near calm and calm until 10:00 PM.

Having rounded Cape Romanzof, I proceeded $\mathrm{N}$ by $\mathrm{E}^{51}$ and $\mathrm{NNE}$ along the coast. At 10:00 AM on the 30th, we passed abreast of the low spit which stretches northward from Cape Romanzof. ${ }^{52}$ We were six miles from the spit at the time, in more than 5 sazhens of water over a bottom of fine gray sand. A steady wind blew from $\mathrm{W}$ by $\mathrm{S}$ under alternate cloudy skies and overcast. The ocean depth de- 
creased and I sent ahead a baydarka with a lead to determine when we approached a shoal. Having taken this precaution, we sailed on till noon and as soon as the baydarka signaled us that it was in 2 sazhens of water, we made a port tack. The coast we saw remained $\mathrm{NE}$ by $\mathrm{E}$ half $\mathrm{E}$ of us at a distance of 6 or 7 miles. This was the last we saw of land until we arrived at Stuart Island.

In sailing northward, I always tried to keep close to the coast, but the shallow water which I kept encountering prevented me from doing so.

All day long we had overcast and a steady wind at WNW and W. The clouds threatened the rapid approach of a storm, so I feared being close to shallow water and kept to depths of 7 or 8 sazhens or more.

At 2:00 AM on the 2 nd we sighted Stuart Island, ${ }^{53}$ at which time we were 15 miles $\mathrm{W}$ by $\mathrm{S}$ of it; a fairly brisk wind blew incessantly from $\mathrm{S}$ by $\mathrm{W}$ and we had alternating overcast and rain. I did not want to ride at anchor in a gale, so I turned seaward and moved under light sail until the wind abated somewhat. As soon as the weather cleared, we turned about and made straight for Stuart Island, which lay 10 or 11 miles ESE of us. By noon the weather had cleared enough to allow us to take the mid-day reading of the sun's altitude, which showed our latitude to be $63^{\circ} 47^{\prime} 27^{\prime \prime} \mathrm{N}$ and our longitude to be $163^{\circ} 30^{\prime}+W$. Stuart Island was $84^{\circ} \mathrm{SE}$ of us at a distance of 15 or 20 miles.

The clear weather would have allowed us to undertake our description [of the coastline], but the wind at S and SSW was completely contrary. This considered and to give the crew a rest, I decided to go to Stuart Island, choose the best anchorage and await a favorable wind that would take me south of the island.

The weather continued good and having a light air at SSW, I held as close as possible to the island, which was not more than $11 / 2$ miles away.

Although the central part of Stuart Island is hilly, its coastline is low-lying. In general, the northern part of the island is higher than the southern part; to the west of the island and apart from it are many isolated rocks with a great abundance of driftwood on them. We saw many huts on this part of the island, but not a single person. After rounding the northeastern cape of the island, we cast anchor in 5 sazhens of water over a slurry bottom. 
Our sojourn to Stuart Island. A meeting with its inhabitants. A description of them: their way of life, the appearance of the men and women. A remark on the disease afflicting them. Their clothing. Other adornments. They slit their lower lip. A remark on their large and small baydarkas. Their food. Their quadrupeds. Birds. Fish. Whence the mainlanders and islanders get their iron and pewter goods and their glass labrets. The language of the islanders and the mainlanders. A selected glossary of words.

As soon as we dropped anchor, Mr. Etolin and I set out for shore in baydarkas. Having reached it, we disembarked at a settlement near a small stream. We did not find anyone in the settlement, but shortly after our landing at the settlement, some one-hatch baydarkas appeared from around the east side of the island. At first they approached us very slowly and gave every indication of being afraid, but our friendly greeting soon emboldened them. Having put in at the same place where our baydarkas were, they stood silent for a long while and would not answer our questions. After they had taken a good look around, so to speak, one of them asked us whence and why we came. Our answer reassured them. Our questioner subsequently proved bolder and friendlier than the rest. His companions immediately set about bartering. They offered beaver, otter, and caribou skins but asked a great deal in exchange.

An islander of advanced years told us of the island they inhabited and called it Kikh-takh-pak, ${ }^{54}$ then in the sand he sketched the mainland coast of America from that island to the Kuikhpak ${ }^{55}$ [Yukon] River and somewhat to the south of it. His testimony and my recollections of the Kuikhpak River and the coast on either side of it were in complete agreement. The islander told me that last year a three-masted ship had come to them and, apparently, had asked if they had seen a single-masted ship. From the question I concluded that the ship was the sloop Otkrytie. The islander showed me a kitchen knife he had obtained from the ship.

When the trading ended, we returned to the brig. Soon about 35 baydarkas gathered around our ship. The Americans sat in them one or two to the baydarka. Their joy was unspeakable. One of them delivered a long speech in sing-song, often mentioning our ship and the word kashat; others, without leaving their baydarkas, ran their hands over their head, face, and chest then turned their hands palm up and extended them toward us, showing thereby that they were as peaceful as we. 
The islanders we knew, those whom we had seen previously on the island, said that the Americans who were with them lived on the mainland cape opposite the strait in a settlement called Tauk, ${ }^{56}$ which, they indicated, lay to the SE of our brig.

These savages were all of medium height. They wore one or two whale skin kamleikas [raincoats] over their parkas of ground squirrel skins. On long journeys, they lash these whale skin raincoats to their baydarka hatches as a covering. ${ }^{57}$

Soon bartering began: the islanders and the Americans traded us beaver, fox, and otter skins for iron knives, kettles, pewter pipes, and Cherkass tobacco. They often complained that we paid them less for their furs than did the Aziagmiut.s8 The bartering ceased about midnight and the Kikh-takh-pags set out directly for the settlement we had visited during the day, but the Americans paddled into the strait. The Americans said they would return at daybreak. As soon as the islanders had assembled in their settlement, they lighted fires at many points along the shore. We concluded that they were fishing, which would explain the fires at the water's edge.

We had a steady wind from the SW through the night until morning with alternating cloudy weather and overcast.

The next day, the 3rd, at about 5:00 AM we were again surrounded by a few Americans. They did not offer anything for trade, but invited us ashore. In answer, I dispatched several baydarkas in charge of Mr. Karsanovskiy, our clerk, and I ordered Karsanovskiy to await me on shore. Meanwhile, I sent all the rowboats for wood and water and I ordered them to put ashore at the place where our baydarkas had put in and after dinner I myself went to the settlement.

The wind continued steady between $\mathrm{S}$ and $\mathrm{W}$ with cloudy and rainy weather. My American acquaintances met me as I landed, but the others sat about in groups undoing and laying out their bartered goods, apparently not paying the slightest attention to us.

Having taken a few steps from the landing place, I was detained by the Americans who showed me their pipes and demonstrated their poverty by various gestures, saying that they could not get tobacco during the trading. To get rid of them quicker, I gave each of them a couple of leaves [of tobacco] and they sat right down on the spot and began to light their pipes. I then noticed that each of the women had a tinder, flint, and steel, which I learned later they obtained from the Aziagmiut. 
One cannot tell a Stuart Islander from an inhabitant of the opposite mainland, for they wear the same kind of clothing, look alike, and speak the same language. At that time there were about 100 men in the village and nearly as many women. They were all of medium height and did not differ in the slightest from the Aglegmiut and the Nunivak Islanders; the similarity of their customs and language leads one to conclude that all these people formerly comprised a single tribe and that various upheavals had scattered them along the entire coast of northwestern America, from KenaiGulf [Cook Inlet] to Kotzebue Sound. ${ }^{59}$

In general, the men and the women have a weak constitution and are spare; I do not know whether to ascribe this to a lack of food (a frequent occurrence) or to the immoderate use of tobacco. The Americans did not have a chief, but often during barter they would consult their shaman and they showed some respect for him in our presence.

For the first time in all my years on the northwest coast of America, I observed a pernicious venereal disease among the people, a disease which had spread to such a degree that many of those suffering from it were greatly disfigured. The face and body of such persons were covered with deep sores. I saw the particular disease called malignant abscesses. ${ }^{60}$ The shaman treats all such maladies, he often contrives some sort of medicines, casts a spell on the wound, etc., but none of this arrests the spread of the pernicious disease in the slightest and it ravages this unfortunate tribe without let or hindrance.

I observed that the females are more infected than the males, which is supported by the fact that we saw more women without noses than men. The men generally are clothed in parkas made of ground squirrel skins, with the fur side out. The under garment of the men and women is identical. Generally, it is made of seal skin or raven's-duck skin, the former being worn by the men and the latter by the women. The footwear of both sexes is identical; it consists for the most part of soft Chukotsk reindeer skin boots, which they get through trade with the Aziagmiut. The women also wear the parka, which they make from the hides of young caribou.

Males up to 14 or 15 years of age wear the same ornaments as the women: they adorn their neck with beads of various colors and with sky-blue bangles; in addition, the women wear an arm ornament of several iron and copper rings. 
Both sexes have black, coarse hair; the men wear their hair close-cropped, while the women plait their hair in two braids, which they wear over the temples and which they smear generously with grease.

The men slit their lower lip through on both sides of the mouth and place a [sky-blue] glass bead or a worked stone in the opening. Both the men and the women slit their ears from the top downward, but in place of earrings the men use well-polished bones and the women wear a blue glass bead and small thongs.

Their large baydaras and their baydarkas are identical to those we saw among the Aglegmiut and the inhabitants of Nunivak Island. ${ }^{61}$ For the most part, these people depend on the bounty of the sea for their food. In summer they catch many fish and in spring and fall they hunt the caribou. They eat the meat of the caribou and trade its hide to the Aziagmiut. Caribou not only inhabit the mainland coast, but Stuart Island as well, for we saw many signs of them on the island.

We saw different kinds and vast numbers of birds along the island's coast: for the most part they were the same as those found along the coast of Kamchatka.

The fish here are exactly the same as those caught in the Nushagak River. There are very many quinnat salmon and the natives not only use them for food, but render their fat and store it in bladders; further, they make women's clothing from the skins. ${ }^{62}$

These Americans make some attempt to hunt animals in winter, but only to have something to trade the Aziagmiut for pewter pipes, knives, some tobacco, and glass labrets. They spend the rest of the year in idleness, caring little for the future, and often going hungry.

The women are absolute slaves to the men. They do the heaviest work and prepare the winter provisions. During nomadic wanderings, they carry the loads or paddle the baydarkas. They build the dwellings, etc.; in a word, they do all the domestic work.

The Stuart Islanders and the Americans speak the same language, which is similar in many ways to the language of the Aglegmiut and the Nunivak Islanders, as may be seen from the words that follow. ${ }^{63}$

$\begin{array}{lcc} & \text { Stuart Islanders } & \text { Nunivak Islanders } \\ \text { Man } & \text { Nugalpyak } & \text { Nugaspyak } \\ \text { Woman } & \text { Agnak } & \text { Agnak } \\ \text { Old Man } & \text { Aguk } & \text { Anusmogak }\end{array}$




\begin{tabular}{|c|c|c|}
\hline & Stuart Islanders & Nunivak Islanders \\
\hline Old Woman & Agnal-kvaak & Agnaskuagak \\
\hline Child & Tapugak & Tapgugikhat \\
\hline Girl & Vilgak & Aganok \\
\hline Life & Uguvan & Ituan \\
\hline Death & Tuku & $\begin{array}{l}\text { Niksinakh-Kimok- } \\
\text { Piyatut }\end{array}$ \\
\hline Animal & Yuguvalga & Nuvelrrek \\
\hline Bird & Tkhymyat & Tynyammyak \\
\hline Food & Nyka & Nok-siyapyt \\
\hline Father & Adaka & Atakka \\
\hline Mother & Anaka & Annaka \\
\hline Son & Avakudaka & Avakutaka \\
\hline Wife & Nulyalyaka & Nuleaka \\
\hline Daughter & Panaka & Paniika \\
\hline Brother & Agnaka & Uyu-agakka \\
\hline Sister & Alskaka & Alskaka \\
\hline Scoundrel & Magliyu & Maglit \\
\hline Friend & $\begin{array}{l}\text { Kunukitukuk } \\
\text { Igylkaka }\end{array}$ & Kunukaka \\
\hline Eye & $\mathrm{Ik}$ & Igikka \\
\hline Nose & Knak & Knaka \\
\hline Mouth & Kipykh & Kapka \\
\hline Teeth & Kkhutyt & Kkhutet \\
\hline Tongue & Ulyu & Ulyuka \\
\hline Ärms & Talik & Aykhanka \\
\hline Legs & Igut & Ityganka \\
\hline Iron & Chavyk & Mylskhagakh \\
\hline Yurt [Tent or house] & Ierna & $\mathrm{Na}$ \\
\hline Rain & Ivyzhuk & Ivyyuk \\
\hline Fog & Taytuk & Taytuk \\
\hline White & Ikuk & Katagali \\
\hline Red & Kavykhtak & Taiglagola \\
\hline Black & Tangyk & Chumykhehitok \\
\hline Dark-blue & Ämzhak & Chumykhtok \\
\hline Poorly & Ikchu & $\begin{array}{l}\text { Keyanyamotok } \\
\text { Piyakhtut }\end{array}$ \\
\hline Wet & Imugnakhkuk & Chutuk \\
\hline Thin & Amipakakhtut & Chinygitok \\
\hline Thick [Fat] & Ikukhpyt & Channuk \\
\hline Much, many & Amlykhla & Amylskhtut \\
\hline Little, few & Ikkhadok & Ikkhadok, piyakhtut \\
\hline Sea water & Tagyu & Tag-yuk \\
\hline River water & Myk & Mok \\
\hline Bay & Chlya & Tachik \\
\hline Fox & Kavsyak & Kafiyagat \\
\hline Beaver & Pamoktat & Pamoktat \\
\hline Ears & Chutyt & Chuat \\
\hline Hair & Nuyat & Nukht \\
\hline Fish & Ikalyukhpyt & Ikazyu \\
\hline Right hand & Paliyapik & Talekhnika \\
\hline Left hand & Chaumyk & Iksyukha \\
\hline Baydarka & Kayak & Kayak-kayagukht \\
\hline Oar [Paddle] & Agvaun & Anuagon \\
\hline Beluga & Chtvat & Chtot \\
\hline Fire & Knyk & Kynyk \\
\hline Smoke & Antuk & Puyuk \\
\hline North & Vaslak & Nyshkfak \\
\hline South & Nyshkvakhtuk & Uvankhnyak \\
\hline East & Pykhkin & Agnynik \\
\hline West & Klyuvakhtuk & Nakik \\
\hline Evening & Akfavok & Akfovok \\
\hline
\end{tabular}




\begin{tabular}{|c|c|c|}
\hline & Stuart Islanders & Nunivak Islanders \\
\hline Morning & $\begin{array}{l}\text { Unoak } \\
\text { Uglayak }\end{array}$ & Unoak \\
\hline Whale & Agyvgyt & Agobok \\
\hline Walrus & Ayv-gyt & Azibok \\
\hline Strong & Aymokakhtuk & Kilkhlyukh-piyakhtut \\
\hline Weak & Akhtuyagutuk & $\begin{array}{l}\text { Kipglyaklyuk- } \\
\text { piyakhtut }\end{array}$ \\
\hline Sky-blue & Chugakhtok & Chupivyk \\
\hline Knee & Chatkuk & Chatkok \\
\hline Elbow & Ikuvak & Ikuik \\
\hline Brow & Chuguk & Kavka \\
\hline Beard & Ugash [Ugat?] & Talomok \\
\hline Nostrils & Pachagvok & Knykhka \\
\hline Dog & Kimukhtat & Keymukhta \\
\hline Wolf & Kiglupgyt & Kagonyk \\
\hline Bear & Tagukak & Tevutaguka \\
\hline Distant, far & Yakishkhtok & Yay-khtok \\
\hline Near & Kantok & Kantuk \\
\hline Here & Fani & Tavontok \\
\hline There & Yak-vaagni & \\
\hline $\mathrm{I}$ & Va-vyagalu & Kivui \\
\hline Thou & Lspyt & Lspyt \\
\hline $\mathrm{He}$ & $\mathrm{Um}$ & Um \\
\hline She & Una & Una \\
\hline To sleep & Kavikhtuk & Kvakhchikua \\
\hline To arise, get up & Tubakhtva & Siyakkhto \\
\hline Good-bye & Tay-Tay & Anchekuan \\
\hline Hare & Aklankkhudyt & Katagalit \\
\hline Deep, it is deep & Itok & Itok \\
\hline Shallow, it is shallow & Itkhaduk & Itkhadok \\
\hline Hot, it is hot & Uknakh-kuk & Ukhnagovyak \\
\hline I love & Igylkaka & Kunukhaka \\
\hline Rich & Tukukali & Kashaguk \\
\hline Poor & Tligaykana & Naslinaluk \\
\hline To trade, barter & Iguukhtukuk & Kopuuchikuk \\
\hline Mosquito & Mlyugzhok & Mlyumygyt \\
\hline Early, it is early & Akhgzhvakhchikva & Piyakhta \\
\hline Large river & Kvikhpak & Kupkh gannitok \\
\hline Late, it is late & Akhgzhaganaytva & Nukafnatnokhtok \\
\hline After & Adakua & Tavantok \\
\hline This & Una & Una \\
\hline Pot & Gan & Knegevyp \\
\hline Arrow & Kkhut & Kkhupyt \\
\hline Bow & Uglugyt & Ugolovok \\
\hline Today & Ignykhpesk & Aganykhpak \\
\hline Tomorrow & Unovaku & Unoak \\
\hline
\end{tabular}

\section{COUNTING}

$\begin{array}{lll}\text { One } & \text { Atavchik } & \text { Atavchik } \\ \text { Two } & \text { Ay-pa } & \text { Ay-pa } \\ \text { Three } & \text { Pigakhva } & \text { Pinga-yu } \\ \text { Four } & \text { Chtami } & \text { Chtamik } \\ \text { Five } & \text { Talimi } & \text { Taslimik } \\ \text { Six } & \text { Agvynga } & \text { Agvyngog } \\ \text { Ten } & \text { Kulgukhtok } & \text { Kulin } \\ \text { Twenty } & \text { Yuy-nak } & \text { Chuynak }\end{array}$




$\begin{array}{lll} & \text { Stuart Islanders } & \text { Nunivak Islanders } \\ \begin{array}{l}\text { Difficult, it is } \\ \text { difficult }\end{array} & \text { Ugamaytuk } & \text { Kamiytok-piyakhtut } \\ \text { Easy, it is easy } & \text { Ukikhyduk } & \text { Uksyuk-chugok } \\ \text { No } & \text { Pituk } & \text { Piytok } \\ \text { Needle } & \text { Myikun } & \text { Chikugaiyk } \\ \text { Uncle } & \text { Agaka } & \text { Anakhslyugak } \\ \text { To dance } & \text { Lilygvok } & \text { Azikhtuk } \\ \text { Summer } & \text { Kiyaktuk } & \text { Kiek } \\ \text { Spring } & \text { Upynykhkak } & \text { Upynykhkan } \\ \text { Winter } & \text { Uksyuk } & \text { Uksyuk }\end{array}$

\section{VI}

Survey of the strait by baydarka. Departure from Stuart Island. Journey to Cape Darby. Arrival at Golovnin Bay. A meeting with Americans. Realization that Golovnin Bay communicates with the Kaviyak or Kheuveren [Kuzitrin] River. An American named Tungan informs us of some Russian names and tells us of St. Lawrence Island.

As soon as the weather improved, I sent Mr. Etolin and several baydarkas to investigate the strait and to survey, in as far as possible, the part of the mainland coast that extends southward from the strait. I sent my clerk Karsanovskiy with two baydarkas to the settlement of Tauk to determine how populous that village was.

The Americans left Stuart Island and we did not see them there after four o'clock. Apparently there are no permanent American dwellings on the island and the settlement is used only as a shelter during the trading season.

Mr. Etolin returned to the brig late in the evening. First he had gone to the east cape of Stuart Island, where he landed his baydarkas and scanned the whole coast from that elevation. It ends in high ground. Mr. Etolin encountered a sand bar toward the SE and had to return to Tauk.

The strait which lies between the mainland and Stuart Island is not more than 112 miles wide, according to Mr. Etolin's description. The strait is 4 and 3 sazhens deep near the middle, while nearer the island it is 4 or 5 sazhens deep, but only in places. Everywhere the bottom consists of tough silt.

Karsanovskiy reported that the Americans in the settlement had treated him very kindly. He counted about 40 houses $^{64}$ of various sizes and said there were about 200 Americans of both sexes in the settlement. They offered him only fresh and dried fish in trade. He also said that he had seen dogs on the shore and near the huts many 
sleds, which, he said, were identical to those we had seen among the inhabitants of Nunivak Island.

A steady south wind prevented me from fulfilling my mission. To keep from delaying our visit to the other places cited in my Instructions, I immediately weighed anchor and headed northward.

On the 5th, at 8:30 AM, we began to steer NW directly toward Cape Darby ${ }^{65}$ At first we had a fairly brisk wind from the S, with alternating clear and cloudy weather, but it fell completely calm before noon. Our observations showed that at noon our latitude was $63^{\circ} 49^{\prime} \mathrm{N}$ and our longitude $162^{\circ} 29^{\prime}+\mathrm{W}$. The northern end of Stuart Island was $32^{\circ}$ and 10 miles to the SE of us and Bezborug [Besboro] Island ${ }^{66}$ was $35^{\circ}$ and 31 miles to the NE. The lead showed a depth of 10 sazhens. The calm continued until 12:30 PM, when a steady breeze rose between $\mathrm{S}$ and $\mathrm{E}$. We proceeded NNW half W and the weather continued to be quite good, but overcast concealed the northern coast of Norton Bay from us. When the overcast dissipated a little, we sighted Cape Darby to the NW. When we were 6 or 7 miles from the cape, the sailors began to shout that they saw a ship under sail, but on looking more closely they discovered that what they had seen were two vertical rocks which looked a great deal like a ship under sail.

At 6:00 PM, after rounding Cape Darby, which was then $50^{\circ}$ to the NE of us at a distance of about $1 \frac{1}{2}$ miles, we began to steer NW $1 \frac{1}{2} \mathrm{~W},{ }^{67}$ directly into Golovnin Bay. We had a fairly steady wind from the SSE, with overcast and rainy weather. The ocean depth decreased from time to time.

At 8:30 PM we dropped anchor in 4 sazhens of water about a mile off shore. Cape Darby was $57^{\circ}$ and about $11 \frac{1}{2}$ miles to the SE of us, Rocky Point ${ }^{68}$ was $10^{\circ}$ and $71 / 2$ miles to the SW of us, Gribanov Island ${ }^{69}$ was $86^{\circ}$ and $41 / 2$ miles to the NE of us, and the settlement Chinik ${ }^{70}$ was $40^{\circ}$ and 6 miles to the NW of us.

We had a fresh $\mathrm{S}$ wind all night long with rain and overcast. The next day at about 2:00 PM the wind lulled a bit after shifting from $\mathrm{S}$ to SSW.

At 6:00 PM two one-hatch baydarkas carrying the Americans Chikun and Taypa arrived from the settlement Uzhigalit. ${ }^{71}$ They recognized me immediately and approached our brig without apprehension. Once aboard, our guests were very happy to learn that we had brought much tobacco and many pewter pipes; in fact they danced up and down with joy and, going up to every sailor, said "kuyanna-kuyanna" (that is, "Our friends! Our friends!').72 
Soon Chavysmyak, the chief, whom I had given a silver medal the year before, arrived. He had seven men and two women with him in his baydara. The Americans who were with us told their countrymen everything we had told them and, embracing each other for joy, every other minute they shouted "kuyanna!!"

Chief Chavysmyak did not have the medal I had given him, he said that he had given it to his son and then he showed me a bronze medal that he probably received from Captain Vasilev, for it was identical with the one I had seen on Nunivak Island. Chavysmyak told me that four days after my departure from the bay last year, a three-masted ship had approached Cape Darby. He had gone aboard that ship and received the medal from its commander. He said, however, that the ship did not cast anchor and that he had not seen it subsequently and thus did not know where it had gone.

My friends stayed aboard the brig until sunset, then they took their leave and set out for shore. Some of them made directly for Chinik, probably to inform their countrymen of our arrival.

The next morning at sunrise, the Americans again surrounded our ship in two large baydaras and 12 small, one-hatch baydarkas. In all there were 32 men and women. Our acquaintances came aboard, and by virtue of this acquaintanceship represented their countrymen in barter. The others did not leave their baydaras and baydarkas but stayed near the brig. As soon as the trading began, I set out for Uzhigalit, thinking that I could buy some fresh fish for my crew there.

Some of the Americans accompanied me right up to the shoreline and then returned to the brig. I put in directly opposite the place where we had cut wood the year before. This spot is about 50 sazhens south of the dwellings. There we found the remainder of our firewood, the Americans had not touched a single stick of it, probably thinking that such an action would be punished. From there I went to Uzhigalit where I was met by two old women who were not the least afraid of me, since they knew me. They approached us and invited us into their huts where they served us various dishes prepared according to their taste.

They gave us a fair amount of fresh fish and a goodly amount of dried fish in exchange for needles and tobacco. Having obtained everything I needed, I returned to the brig where the trading was still underway. The Americans offered us beaver and fox skins for iron knives, spears, and tobacco. Meanwhile, I inquired about 
Golovnin Sound. (I called it a sound, for the stories I had heard about it indicated that it communicated with another body of water.) I asked which body of water it communicated with and where one could go from there. Of our visitors, two Americans, Nuksyuk and Abysk, had recently returned by way of the aforesaid communication. They said that the headwaters of the Kweigat Tuksmuk River, ${ }^{73}$ which empties into Tachik [Golovnin] Bay closely approach another river that empties into the sea and which they called the Kaviyayak River. ${ }^{74}$ They stated that it is quite difficult to get from one river to the other because of Mount Kinkhtyryuk, which is in the way, but that the mountain is not very steep and travelers always portage their baydarkas and baydaras over it. Accordingly, I will henceforth speak of Golovnin Bay, not Golovnin Sound, the more so because I now know that the word tachik in the American language means bay.

When the trading was concluded, the Americans bade us farewell and went to Uzhigalit.

All night long we had overcast alternating with rain, with a light air from the NW. Evidently wet weather does not deter the Americans in the least, for by early morning they had again begun to collect around our brig and by noon four large baydaras and eight small, one-hatch baydarkas had assembled. Naglin, an old man and my acquaintance, came from Cape Darby. With him was his eldest son, who wore a bronze medal about his neck. He stated that this medal, too, had been obtained from Captain Vasilev. An American named Tungan, whom I did not know at all, showed us many animal skins, but did not offer a single one for trade. Our guests, who had begun to bore us with their frequent visits, stayed until 4:00 PM and then set out for the nearby shore..$^{75}$

As soon as the weather cleared, I went ashore. My clerk Karsanovskiy followed me to engage in barter; we put in at the rocks opposite Uzhigalit. One cannot imagine the joy with which the Americans greeted us. The words "kashat kuyanna!" were repeated loudly numerous times by the crowd of savages. Many of them, crowding each other, ran to our baydarkas and very carefully removed them from the water. Finally, calming down a little, they dispersed and reassembled in groups in various places. The women were quite apart from the men; having kindled a fire, they prepared supper for the men and took no part whatever in their conversation. Karsanovskiy immediately began the bartering and I, accompanied by some Americans, set out for the lakes that were not far from the 
settlement. My guides followed me until I fired at a snipe, a redshank. After this none of them dared to approach me and when I called to them, they remained silent.

My hike to the lakes was not in vain: I shot a fair amount of game and by evening I returned to our landing site. The barter with the Americans was terminated and Karsanovskiy prepared the baydarkas for departure. During the bartering, the American Tungan had told him about some Russians, whom he called Vasilev and Vorobev.

Although it was already late, I decided to stay ashore to inquire further about Vasilev and Vorobev. For a long while Tungan would not comply with my request to repeat his stories, protesting that he could not speak with us long because his eyes hurt terribly. Finally I won him over and he told us the following story. While he was traveling from the settlement Nykhta ${ }^{76}$ (on Cape Prince of Wales) to Golovnin Bay, a storm came up suddenly and carried him out to sea in his one-hatch baydarka. For two nights* the storm carried him he knew not where and on the third night he arrived in a strange land. Its inhabitants immediately received him in a kindly manner and he remained there a long time, but he had no idea how many years he spent with these people. He learned that the land to which he had come was a long island inhabited by a poor people who live on whale and walrus meat. They traded the walrus skins in the neighboring land, which was one night's journey from the western end of the island. He called this land Kuslit and it was there that he had seen the aforementioned Russians a number of times.

Tungan, wishing to comment on the places to which his unexpected journey had taken him, found a smooth spot on the sand and sketched the American coast from where we were to Bering Strait; then he sketched the nearby island. The island closest to Golovnin Bay he called Aziyak [Ayac, or Sledge Island]; the next island farther' up the coast he called Ukivok [King Island] and said that it was inhabited. The people live on the steep cliffs and for the most part trade furs with the peoples who live in Kuslit; next he delineated two large islands and to the south of them, a tiny islet, giving each of them its own name. Finally, he formed the American coast into a cape opposite those islands and from this cape continued the coast, as one would expect, northward; in marking out the aforementioned coast, he would often draw a line incorrectly, redraw it, and turning takes.

*In general, the Americans reckon a long journey by the number of nights it 
to his countrymen would say that at this point the coast takes such and such a turn.

He sketched in the Kavsyak River ${ }^{77}$ opposite Ukivok Island, saying that the inhabitants of that island often visit the river and sometimes, toward autumn, they travel to Golovnin Bay. He then proceeded to draw the land where he had spent such a long time, designating it as a long island and saying that the inhabitants call it Chuakak.* At the eastern end of St. Lawrence Island he drew three small islands, saying that the northern island has a steep mountain and that there is a dwelling at its foot. He called this islet Punuk. ${ }^{78}$ Finally, he drew Kuslit, saying that he had seen the Russians Vasilev and Vorobev there, and as proof of this he spoke several words which he had often heard the Russians say. Tungan said the following: Papush tabaku [a bundle of tobacco leaves], trubka tabaku [a pipe of tobacco], and proshka tabaku [snuff] and, in addition, he pronounced some curse words used by our common people.

As a conclusion to these tales, I must mention that the storm had carried Tungan to St. Lawrence Island, which is evident from the sketch and undoubtedly he could have visited the east coast of Asia often and have seen Russians, for, as he had already stated, the inhabitants of St. Lawrence Island often travel to the Asian coast to trade walrus skins. Taking everything into consideration, it may be assumed that Tungan could have gone to the Anadyr River where, one would think, he saw Vasilev and Vorobev who, according to his stories, traded with the savage peoples, a trade that may have been conducted by private persons.

Tungan related that last year he had left Kuslit with some Ukivok Islanders and then had crossed the Kaviyayak and Kweigat Tuksmuk rivers and had reached his homeland.

When our conversations had ended, I set out for the brig and asked my new acquaintance to visit me on the ship the next day. The Americans, including Tungan, arrived at 4:00 AM and I invited Tungan into my cabin and repeated last evening's conversation. He drew on paper all those coasts which he had drawn in the sand, exactly as he had done before. Through Tungan I was able to learn

*Perhaps the discrepancy in the naming of St. Lawrence Island, which Mr. Kotzebue called Chibono and which Tungan called Chuakak, stems from the fact that Tungan was a foreigner there or perhaps it is due to the imperfection or the characteristic of the language. Similarly, various Europeans called the late king of the Sandwich Islands different names and each considered himself correct. 
something of the language of the inhabitants of Chuakak or St. Lawrence Island. I list below the words I collected. ${ }^{79}$

\section{WORDS IN THE CHUAKAK ISLAND LANGUAGE}

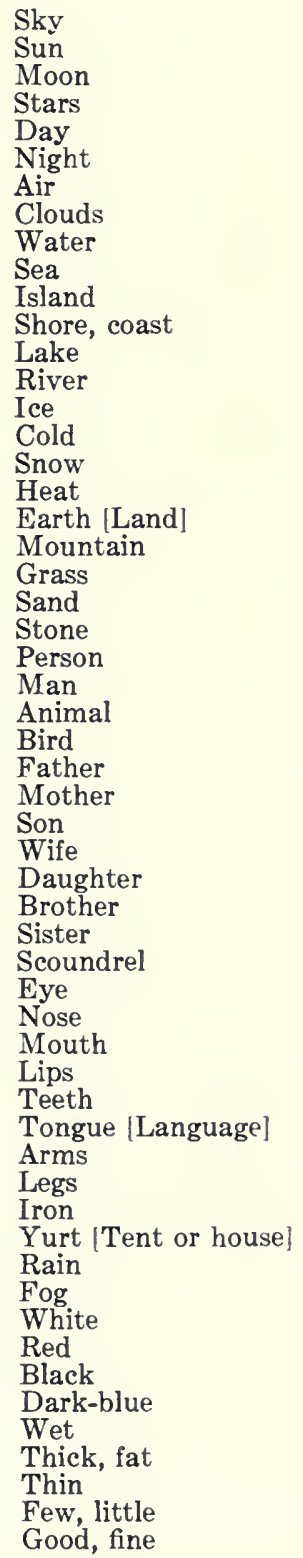

Chlya

Chikinyk

Takik

Ialktagit

Aganik

Unuk

Itelya

Makslyuk

Mok

Imak

Kiikh-kagat

Ischiyak

Nayvagak

Kiyuk

Chikuk

Nankanam Chapakhnak

Aniyu or Kapyyukhta

Nankinam pusklya

Nuna

Nayagat

Vygat

Chirgak

Knak gak

Yuk

Agnak

Unuvak

Kavak

Atanna

Nang-a

Avakutakha

Nulekhka

Panikha

Uyugaka

Akaka

Tukusleka

Chikhka

Knaka

Kanka

Kazikhnya

Kkhutany

Ulyuna

Aykanka

Ityganka

Chavygak

Nygli

Nypchuku

Tachituk

Kkhchuktak

Kavynguk

Molikkhtat

Nankinam Chuno-tana

Chusmoguk

Umuk

Umystagak

Polyakhaguk

Pinatana 
Poorly, it is poor

Sea water

River water

Bay

North

South

East

West

Evening

Morning

Whale

Walrus

Fox

Sable

Far, it is far

Near, it is near

I

Thou

$\mathrm{He}$

To sleep

To arise, get up

Hare

Deep, it is deep

Shallow, it is shallow

Look!

Hot, it is hot

To trade, barter

Early, it is early

Large river

Pot

Difficult, it is difficult

Easy, it is easy

No

Needle

Hatchet

Uncle

To dance

Summer

Spring

Winter

Fall

Chirliguk

Taga-yuk

Mok

Nayvagak

Nikagya

Azivak

Akiknak

Pakvaslya

Akuvan

Unak

Inutuk

Ayvok

Kaviyaka

Avchinikhpak

Uyagantuk

Kantakhantu

Khoona

Ilskhinapyt

Uneskhoni

Kavasninya

Takhtua

Ukazigak

Uskauk

Kakhkatagauk

Iskhagu

Uguk-nakun

Tukhyrlyaku

Chunislyutyn

Chukaniton

Kumysin

Unikhtok

Uknikhstaguk

Avituk

Chukugak

Kayugun

Anaga

Avuslyakh

Upyraga

Uksyak

Uksyuk

Kiyumira

\section{COUNTING}

One
Two
Three
Four
Five
Ten
Twenty
Thirty
Forty

Atavchigak

Mamofik

Prengayu

Staman

Tasliman

Ullya

Yuvyynak

Kulmoga olinktok

Yu-u-malgok

The Americans stayed aboard the brig until two o'clock, after which they set off for different points. When Tungan departed, I presented him with a silver medal from among those given me for distribution among the savage peoples. Tungan begged me for a 
trap, explaining that he would show his countrymen how to use it; he had told us earlier that he had often seen traps at Vasilev and Vorobev's place and that he knew how to set a trap and what safety measures to take in doing so.

Tugan differed in no way from his countrymen with respect to clothing and ornament, but his native intelligence attracted our attention. Although he had little understanding of other lands, he was very curious to know whence we had come, whether there were many other people left there, and who commanded them. As he learned about foreign lands, he invariably wanted to have a sketch of them. He asked me for a scrap of papel and with a pencil he outlined all those distant countries of which I spoke and kept asking "is this the way it is?" Then, turning to his countrymen, he spoke at length with them about it all and finally said: "Oh, how many peoples there are in this land [world] besides us!"

Shortly after the departure of the Americans, Mrr. Etolin and I set out for Rocky Point by baydarka; en route we met our Aleuts and the clerk Karsanovskiy, who were on their way to a dwelling to trade for pelts, but I ordered them to follow me. Without going as far as Rocky Point, we put in opposite a small settlement, where we were met by Chief Chavysmyak and the Americans accompanying him. They conducted us to their dwelling. which was 50 sazhens from the sea. On the way we saw many scaffoldings on which a large quantity of different kinds of fish were drying. Chief Chavysmyak's wife and small daughter served us our meal. They offered us whale meat and boiled fish, but the food had such a repulsive odor that none of us would try it, except for the Aleuts who considered it a great delicacy. We had the opportunity to see an American dance, which Chavysmyak told us was performed only at entertainments. It began as follows: first the men formed a circle, then one of them began beating a tambourine [drum] and singing in a doleful voice, another went into the middle of the circle, leaned a bit forward, and with every gesture stamped his foot, looked in all directions as if he feared someone, then stealthily drew his bow and shot an arrow. All this was repeated in the same order, four times or more, always to the accompaniment of several words spoken in a frightened voice. Then the men, women, and grown children danced together until they grew tired. The American dance is so monotonous that it gives the viewer no pleasure. The women are even less adept [at the dance than are the men and boys]. The Americans, however, love 
the dances of other peoples, which are incomparably livelier and more diverse than their own.

The American singing voice is very rough and unpleasant to the ear; it has little variation and is often despondent. I understand that the Americans have their own poetry, which consists solely of military songs, some heroic and some humorous. The humorous songs are especially popular with these savages. Special persons called "kashats," compose most of these songs and this earns them no little respect among their countrymen. Often the Americans, like the Aleuts or the Yakuts, take some phrase and sing it in chorus, for example, "Ya tabak kroshu, a ty net" [I chop tobacco, and you don't]. Out of boredom, the savages sometimes chant this same song for an hour or more.

After the dance, we watched how the Americans sometimes capsize their baydarkas and without getting out of them, right them again. Chavysmyak told us that they begin learning this art when they are very young so that by the time they reach adulthood they have it mastered.

Here I happened to see a young girl who was already married, although she was not yet ten years old while her husband was perhaps 20 years old or older. When I asked why they gave such a young girl in marriage, her mother answered that if the girl were not married by that age, everyone would laugh at her and come to despise her. Perhaps the ambition or the advantages gained by the girl's father may have something to do with the giving of daughters in marriage at such a young age. The marriage customs of the Americans appear to be identical to those of the Kodiak Aleuts, for after marriage a son-in-law becomes almost a workman in his fatherin-law's house. He always gives his father-in-law the best of his catch, the best object he gets in trade, and the greater part of all he gets.

An American considers himself more fortunate to have daughters than sons, for sons may leave him after marriage, while a son-in-law is obliged to support his father-in-law.

The Americans offered us fully equipped baydarkas in trade, one of which Mr. Etolin obtained for a Chukot spear and tobacco, but not one of the Americans wanted to part with his furs, because we could not give them much tobacco, for which and only which they will trade their fox skins. They are great masters of the art of 
barter; they drive a very hard bargain, always consult each other and, finally, take great pleasure in thinking they have cheated someone. 


\section{NOTES}

1. The Russian text says "Unalaska Strait," but this is presumed to be incorrect (see p. 43). Unimak Pass is one of the principal ship passages through the Aleutian Islands.

2. This term, which literally means "enterprisers," can best be translated in the context as "fur hunters." Actually promyshlenniki served as soldiers, sailors, manual laborers, and traders as well as fur hunters. The term seems to have been applied originally to those individuals who signed up with merchant associations in Siberia to obtain furs in Alaska during the half century preceding the establishment of the Russian-American Company in 1799 (Sarafian, 1970, p. 14).

3. Golovin throughout the Russian text. It is not clear why the name of Khromchenko's ship, that of the famous circumnavigator V. M. Golovnin, is so consistently mispelled.

4. Cape Newenham and Norton Sound, from which the designation for the bay is derived, were named by the Cook expedition in 1778. Derivations of the names of geographical features will be noted only within the region of Khromchenko's explorations.

5. The Eskimo kayak.

6. This term was used for a number of different linguistic groups by the Russians. Most frequently they distinguished between the Aleut-speaking Fox Island Aleut and the Kodiak "Aleut" who are actually Koniag-speaking Eskimos.

7. Literally, a baydarka leader or owner of a baydarka, this term also referred to the appointed leaders in Eskimo settlements. The Yakut term toyon was also frequently used for those individuals appointed by the Russians to assist in obtaining furs from their fellow villagers (see VanStone, 1968, p. 226).

8. A sazhen is equal to seven feet.

9. The Eskimo umiak, a large, open skin boat.

10. Khromchenko is referring to his first visit to the island the preceding summer. Both Hagemeister Island and the strait which 
separates it from the mainland were named, probably by the Korsakovskiy expedition in 1819, for Captain Leontiy Andrianovich Hagemeister, Baranov's successor as general manager of the RussianAmerican Company.

11. Not to be confused with the Russian-American Company's station of the same name at the mouth of the Nushagak River.

12. Khromchenko uses this term to refer to Eskimos from the mainland.

13. According to Eskimos living along the river today, upriver people in the early historic period referred to the Nushagak as the Ilgayak, a place name that has no meaning. Inhabitants of the lower river and Nushagak Bay called the river Tahlekuk which means "elbow," a reference to the shape of its lower reaches. The name Nushagak has no meaning to local people at the present time, nor are they aware of its origin.

14. A reference to the ivory labrets worn by Eskimos in this area.

15. Khromchenko may have been the first to report the Eskimo name for this river. Its earliest appearance on a published map is in 1826 (Sarychev, 1826, map 3).

16. The inhabitants of the Togiak (Togiagamiut) and Kuskokwim (Kuskowagamiut) rivers are Eskimoan speakers of the Western Eskimo language stock (Yupik). This linguistic grouping is separated into three major dialect clusters: Yuk, which includes the coastal and adjacent riverine peoples from St. Michael to Bristol Bay and Iliamna Lake; Cux, spoken only on Nunivak Island; and Suk, spoken on Kodiak Island and the adjacent mainland (Hammerich, 1958, pp. 632-639). It will be noted, therefore, that the Togiagamiut and Kuskowagamiut are both Yuk speakers. The form and design of the kayaks of these areas are essentially the same, although the style changes in the northern part of the area occupied by Yupik speakers (see Nelson, 1899, pp. 218-222, pl. LXXIX).

17. Named by the Korsakovskiy expedition in 1819 .

18. The Eskimo name for this river was first reported by the Korsakovskiy expedition in 1819.

19. Although sighted first by Vasilev in July, 1821, and named Otkrytie after his ship, Khromchenko and Etolin were presumably the first to report the native name for this island (see "Introduction," p. 15).

20. Although Khromchenko sounds knowledgeable concerning the upper Nushagak, the region was not explored until 1830 when an 
overland expedition under the leadership of Ivan Yakovlevich Vasilev ascended the river to its headwaters, crossed over to the Holitua, and descended that stream to the Kuskokwim (see fig. 2). Two years later, Fedor Kolmakov made a similar trip and founded the first trading post on the Kuskokwim at its confluence with the Holitna (Fedorova, 1971, pp. 229-232; VanStone, 1967, pp. 10-11). Although it is something of an exaggeration to say, as Khromchenko does, that the upper reaches of the Nushagak "communicates easily with the headwaters of all the large rivers which empty into the (Bering Sea) northward to Norton Sound," it is true that the Kuskokwim and Yukon can be reached in this manner. Using this route, together with the Yukon, the Russians were able to open all of southwestern Alaska to the fur trade by 1845 (VanStone, 1967, pp. 51-52).

21. The Russian text reads $\mathrm{E}$ by $\mathrm{W}$, but this would appear to be a misprint.

22. Captain James Cook sighted and named Round Island in July, 1778 (Cook and King, 1785, vol. 2, p. 431). The origin of the name Walrus is obscure. Sarchyev (1826, map 3) applied the name to an island which Tebenkov (1852, map 4) identified as the Round Island of Captain Cook. Tebenkov applied the name Walrus Islands to all those east of Hagemeister Island. Today four islands are recognized as belonging to the Walrus group (Orth, 1967, p. 1027) but Captain Cook did not actually hazard a guess as to the total number since he observed very little of the coastline in this area.

23. Named by Korsakovskiy in 1819 for the Russian-American Company ship which supported his explorations.

24. The present-day village of Ekuk.

25. After the establishment of Aleksandrovskiy Redoubt in 1819, Eskimos from the Kuskokwim River were attracted to the vicinity of the post by the opportunity to trade furs.

26. The Russian word igra (performance) is used by northern explorers for ceremonies held in the Eskimo kashgee, or ceremonial house.

27. For a more detailed discussion of subsistence patterns in the Nushagak River region, see VanStone (1967, ch. VIII).

28. For a more detailed description of nineteenth century houses in southwestern Alaska, see Petroff, (1884, p. 15); VanStone (1968, pp. 233-252; 1970, pp. 20-33). 
29. See footnote 16. The Yuk dialect was understood by Cux speakers of Nunivak Island, but not by the Suk-speaking Koniag Eskimos (Hammerich, 1958, p. 639).

30. Portions of the Koniag vocabulary were reprinted in contemporary French and German publications (see Pilling, 1887, p. 51).

31. All species of Pacific salmon make spawning runs into the rivers of Bristol Bay. Khromchenko probably failed to notice this because his visit preceded the big runs which commence in July.

32. Cape Mendenhall.

33. Etolin Strait. This body of water was named Cook Strait by the expedition in 1821 after Captain James Cook. It later received its present name at the suggestion of I. F. Krusenshtern, the Russian circumnavigator (Orth, 1967, p. 320).

34. At the time of enumeration for the eleventh census in 1890 , there were several settlements in the Cape Mendenhall region and five small villages with a combined population of 186 along the coast between Cape Mendenhall and Cape Corwin (Porter, 1894, pp. 111, 113). Presumably Khromchenko's visitors came from a village at the southwestern end of Cape Mendenhall.

35. According to the eleventh federal census, the village of Koot on Cape Etolin was the point of communication with the mainland. At that time, trade was carried on mainly through the village of $\mathrm{Tu}$ nunak on Nelson Island (Porter, 1894, p. 116).

36. Lantis (1946, map 1, pp. 162-163) notes a large winter village on the east coast of Cape Mendenhall near the mouth of the bay, and a summer village at the very tip of the cape. Both were important settlements about 50 to 60 years prior to her stay on the island in 1940. Her name for the summer village closely approximates that of the settlement noted by Khromchenko (see fig. 5).

37. See "Introduction," p. 15.

38. Nunivak Island kayaks are similar to those which Khromchenko had already seen in use by the Togiagamiut and the Kuskowagamiut.

39. Khromchenko was correct in assuming that the Nuniwagamiut lacked formal political organization. As he suggests, recognized leadership qualities included age and experience. Success in hunting was the principal source of personal prestige and such skills gave a man and his family wealth as well as recognized status in the community. These were all factors that contributed to the recognition of an individual as a leader (Lantis, 1946, pp. 247-248). 
40. Lantis (1946, map 1, p. 162) notes a village of this name, which means "point of land," at the tip of Cape Corwin. It was a summer settlement for the winter village of Paimiut, at one time the largest community on the east side of the island (see Fig. 5).

41. For a detailed description of Nuniwagamiut burial practices, see Lantis (1946, pp. 227-228).

42. Heat for the traditional Eskimo baths in this area was supplied by an open fire in the center of the kashgee. Khromchenko may be referring to the water vapour bath involving heated rocks and introduced throughout southwestern Alaska by the Russians (Oswalt, 1963, p. 148; Zagoskin, 1967, p. 224).

43. Possibly Eskimos from the mouth of the Kuskokwim River or from a village on the Yukon-Kuskokwim delta.

44. A river just north of Chinik heads in a small lake approximately five miles inland. There are, however, no islands anywhere off the coast of Cape Corwin. It is possible that Khromchenko is referring to a group of small islets just off shore from the next cape to the north which is unnamed.

45. Nunivak Island, as well as the Pribilofs, consists largely of undissected volcanic topography of Cenozoic age (Wahrhaftig, 1965, p. 32).

46. Named in 1821 by Vasilev for Lieutenant A. P. Avinov who was in command of the ship's boat.

47. Sighted in 1821 by Etolin and named for the British navigator.

48. The Russian text here says NWE, but NNE is presumed to be intended.

49. Cape Manning.

50. Khromchenko apparently missed Hazen Bay, although he observed the coastal hills extending to the northeast from Cape Vancouver (see fig. 2).

51. The original reads $\mathrm{W}$ by $\mathrm{E}$.

52. It is possible that Khromchenko mistook Dall Point for Cape Romanzof. There is no spit extending north of the latter, but one does extend to the south and almost meets a similar spit reaching north from Dall Point. Between these two narrow spits is the entrance to Igiak Bay (see fig. 2).

53. Named in 1778 by Captain Cook. 
54. This is Khromchenko's interpretation of the Eskimo word kikiktapuk which simply means "big island" (Ray, 1971, p. 14).

55. This is the Eskimo name (Kwigpak, "big river") for the lower portion of the Yukon occupied by Eskimos. The Indian word for the upper part is now applied to the entire river.

56. The nineteenth century village of Atuik ("bent point"). Slightly to the south of the site of Atuik is the present-day village of Stebbins, the Eskimo name of which is Tapkak ("sandy beach") (Ray, 1971, pp. 10, 21).

57. The raincoats to which Khromchenko refers were actually made from the dried intestines of seals (see Nelson, 1899, pp. 36-37).

58. The inhabitants of Sledge Island (Ayak; see Ray, 1971, p. 12, footnote 21) in the Bering Sea off the coast of Seward Peninsula approximately 25 miles west of Nome. These Eskimos served as middlemen in the Siberian-Alaskan fur trade which flourished following the establishment of a trading post on the Kolyma River by the Russians in 1789 (Wrangell, 1840, pp. 114-119; Ray, 1964, p. 86). The island received its English name from Captain Cook in 1778.

59. Although a certain degree of cultural uniformity does exist throughout the area explored by Khromchenko and Etolin, there is, as previously noted (footnote 16), a sharp linguistic boundary at Norton Sound.

60. Probably syphilis.

61. Differences between the kayaks of Nunivak Island and Norton Sound are described and illustrated by Nelson (1899, pp. 219220, pl. LXXIX, 2-3).

62. This contradicts Khromchenko's earlier statement (p. 57; see footnote 31 ) that there were only loach in the Nushagak River.

63. Stuart Island is near the northern boundary of the Yupik language. As previously noted (footnote 16), the inhabitants of Nunivak Island speak Cux, a dialect of Yupik.

64. The Russian word used here is yurt which, in exploring accounts dealing with Alaska, refers to both tents and houses. Generally, however, it refers to the semi-subterranean Eskimo house.

65. Named by Captain Cook in 1778 .

66. Named by Captain Cook in 1778 who published it as Besborough Island.

67. Possibly a misprint for half W. It has been impossible to verify a sailing direction one and one-half. 
68. Named by Khromchenko in 1821.

69. Probably Carolyn Island located in Golovnin Bay at $64^{\circ} 27^{\prime}$ $\mathrm{N}, 162^{\circ} 53^{\prime} \mathrm{W}$.

70. The present-day village of Golovin. The name means "point of land."

71. Possibly the now abandoned settlement of Igluchaik on the west coast of Golovnin Bay (Ray, 1964, p. 70; map 1, p. 92).

72. The Eskimo word kuianna means "thank you."

73. Khromchenko is probably speaking here of the Niukluk River, although he appears to have confused the name with the Tuksuk Channel which connects Grantley Harbor and Imuruk Basin. The Niukluk is a major tributary of the Fish River which flows into Golovnin Bay (see fig. 3).

74. A tributary of the Kuzitrin which flows into Imuruk Basin. For a general discussion of settlements and travel in this area, see Ray (1964, p. 69).

75. These visitors may have come from the now abandoned settlement of Atnuk on the east coast of Cape Darby.

76. The Eskimo name for the present-day settlement of Wales, and Cape Prince of Wales, is Kingigan. Nykhta is apparently a wrong pronunciation. Khromchenko's informant is doubtless referring to the settlement.

77. The Kuzitrin River which flows into Imuruk Basin. The latter is connected to Grantley Harbour and Port Clarence by the previously-mentioned Tuksuk Channel.

78. This may be the first printed reference to the Punuk Islands. They do not appear on a published map until 1849 (Orth, 1967, p. 782 ).

79. As noted in the introduction, the vocabularies collected by Khromchenko are valuable for studies of Eskimo dialectology. This is particularly true of the St. Lawrence Island vocabulary which is the earliest for that area. There are earlier word lists for the dialect at Chaplino on the Siberian mainland and by comparing the two, linguists can determine that the Chaplino and St. Lawrence dialects were virtually identical in the 1820's. This information is significant since the present population of the island is almost entirely new, having come from Chaplino. Although nineteenth century epidemics wiped out the bulk of the original St. Lawrence population, linguistic continuity from the earliest historic period can be demonstrated. It 
would appear that Tungan remembered the words well since they can be recognized by a St. Lawrence Islander today, almost 150 years after they were collected. 


\section{REFERENCES}

Bibliographic sources listed at the end of the introduction and also utilized in the preparation of the editorial comments are not repeated here.

HaMmerich, L. L.

1958. The western Eskimo dialects. Proceedings of the Thirty-Second Congress of Americanists, 1956. Copenhagen.

LANTIS, M.

1946. The social culture of the Nunivak Eskimo. Trans. Amer. Philos. Soc., n.s., XXXV, pt. III. Philadelphia.

ORTH, D. J.

1967. Dictionary of Alaska place names. Geol. Surv. Prof. Paper 567. Washington.

OSWALT, W. H.

1963. Mission of change in Alaska. Eskimos and Moravians on the Kuskokwim. San Marino, California.

Petroff, I.

1884. Report on population, industries, and resources of Alaska. Washington.

Pilling, J. C.

1887. Bibliography of the Eskimo language. Washington.

PORTER, R. P. (compiler)

1893. Report on population and resources of Alaska at the eleventh census: 1890. Washington.

RAY, D. J.

1964. Nineteenth century settlement and subsistence patterns in Bering Strait, Arctic Anthro., 2, no. 2, pp. 61-94. Madison.

1971. Eskimo place-names in Bering Strait and vicinity. Names, 19, no. 1, pp. 1-33.

SARAFIAN, W. L.

1970. Russian-American Company employee policies and practices, 17991867. Ph.D. dissertation, U.C.L.A., University Microfilms, Ann Arbor.

SARYCHEV, G. A.

1826. Atlas Severnoy chasti Vostochnago okeana, so stavlen v. chertezhnoy Gosudarstvennago Admiraltezhkago Departamenta, s Novgyshikh opisey i kart, .... St. Petersburg.

Tebenkov, M. D.

1852. Atlas severozapadnykh beregov Ameriki ot Beringova proliva do mysa Korrientes ostrovov Aleutskikh c prisovokupleniem nekortorykh miest Severovostochnago beregov Ameriki, ostrovov Aleutskikh i nekotorykh drugikh miest Severnago Tikhogo okeana. St. Petersburg. 
WaHRHAFTIG, C.

1965. Physiographic divisions of Alaska. Geol. Surv. Prof. Paper 482. Washington.

WRANGELL, F. P.

1840. Narrative of an expedition to the Polar Sea in the years $1820,1821,1822$ \& 1823. London. 








\section{Publication 1172}







UNIVERSITY OF ILLNOIS-URBANA

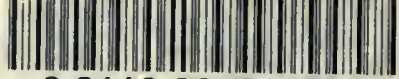
30112037649818 